\title{
IMUNIZAÇÃO NASAL EM COELHOS COM NEISSERIA LACTAMICA: IMPORTÂNCIA DOS ANTÍGENOS DE REATIVIDADE CRUZADA
}

\author{
CLAUDIA FERIOTTI TUNES
}

Dissertação de Mestrado apresentada ao Programa de Pós-Graduação Interunidades em Biotecnologia USP/ Instituto Butantan / IPT, para a obtenção do Título de Mestre em Biotecnologia.

São Paulo 


\title{
IMUNIZAÇÃO NASAL EM COELHOS COM NEISSERIA LACTAMICA: IMPORTÂNCIA DOS ANTÍGENOS DE REATIVIDADE CRUZADA
}

\author{
CLAUDIA FERIOTTI TUNES
}

Dissertação de Mestrado apresentada ao Programa de Pós-Graduação Interunidades em Biotecnologia USP/ Instituto Butantan / IPT, para a obtenção do Título de Mestre em Biotecnologia.

Área de concentração:

Biotecnologia

Orientadora:

Prof $^{a}$. Dra. Elizabeth Natal De Gaspari

São Paulo 
DADOS DE CATALOGAÇÃO NA PUBLICAÇÃO (CIP)

Serviço de Biblioteca e Informação Biomédica do

Instituto de Ciências Biomédicas da Universidade de São Paulo

reprodução não autorizada pelo autor

Tunes, Claudia Feriotti.

Imunização nasal em coelhos com Neisseria lactamica: importância dos antígenos de reatividade cruzada / Claudia Feriotti Tunes. -- São Paulo, 2006.

Orientador: Elizabeth Natal De Gaspari.

Dissertação (Mestrado) - Universidade de São Paulo. Instituto de Ciências Biomédicas. Programa de Pós-Graduação Interunidades em Biotecnologia USP/Instituto Butantan/IPT. Área de concentração: Biotecnologia. Linha de pesquisa: Imunologia - estudo de vacinas.

Versão do título para o inglês: Nasal immunization in rabbits with Neisseria lactamica: the importance of cross reactive antigens.

Descritores: 1. Neisseria lactamica 2. Neisseria meningitidis 3. Coelhos 4. Resposta imune humoral 5. Anticorpo monoclonal 6. Vacinas I. De Gaspari, Elizabeth Natal II. Universidade de São Paulo. Instituto de Ciências Biomédicas. Programa de Pós-Graduação em Biotecnologia III. Título.

ICB/SBIB205/2005 


\section{UNIVERSIDADE DE SÃO PAULO \\ Programa de Pós-Graduação Interunidades em Biotecnologia}

Universidade de São Paulo, Instituto Butantan, Instituto de Pesquisas Tecnológicas

Candidato (a): $\quad$ Claudia Feriotti Tunes.

Título da Dissertação: Imunização nasal em coelhos com Neisseria lactamica: importância dos antígenos de reatividade cruzada.

Orientador (a): $\quad$ Elizabeth Natal De Gaspari.

A Comissão Julgadora dos trabalhos de Defesa da Dissertação de Mestrado, em sessão pública realizada a ................................................., considerou

( ) Aprovado(a) ( ) Reprovado(a)

$\begin{array}{ll}\text { Examinador (a): } & \begin{array}{l}\text { Assinatura: } \\ \text { Nome: } \ldots \ldots \ldots \ldots \ldots \ldots \ldots\end{array} \\ \text { Instituição: }\end{array}$

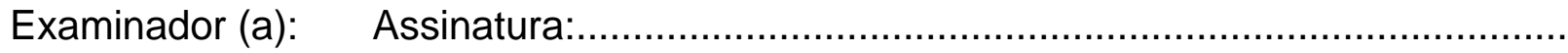

Nome:

Instituição:

Examinador (a): Assinatura:

Nome:

Instituição: 


\author{
SECRETARIA DE ESTADO DA SAÚDE \\ COORDENAÇÃO DOS INSTITUTOS DE PESQUISA \\ INSTITUTO ADOLFO LUTZ \\ CTC/IAL
}

\title{
APROVAÇÃO DE PROJETO DE PESQUISA
}

IAL/CCD/CEPIAL/CTC

PROJETO CCD BM N 03/2003

\section{Coordenador: Elizabeth Natal de Gaspari}

Projeto : Imunização Nasal em Coelhos com Neisseria lactamica: Importância dos Antígenos de Reatividade Cruzada

Inicio: Março 2003

Término: Dezembro 2004

$\mathrm{Sr}^{\mathrm{a}}$. Coordenadora:

Comunicamos que o projeto supra citado foi cadastrado no Conselho Técnico Científico do Instituto Adolfo Lutz, após aprovação na CCD/BM e CEPIAL.

Parecer favorável recebido pelo CTC em 22/4/2004

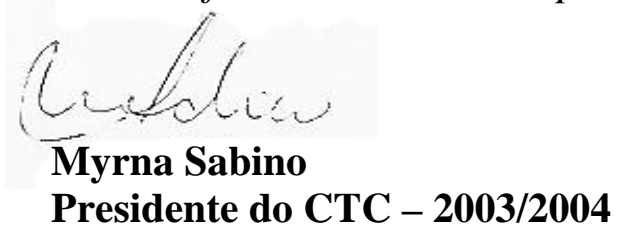

Via 1: Coordenador

Via 2: $C C D / B M$

Via 3: CTC 
Este trabalho foi realizado na Seção de Imunologia do Instituto Adolfo Lutz, sendo o projeto aprovado pelo Comitê Técnico e Científico desta Instituição.

Apoio Financeiro FAPESP Processo 99/005576 


\section{DEDICATÓRIA}

Às minhas queridas, filhas Bruna e Aline que sempre me incentivaram.

Ao Jason, pelo apoio e colaboração, sempre estando ao meu lado em todos os momentos. 


\section{AGRADECIMENTOS}

À Prof. Dra. Elizabeth Natal De Gaspari pelo incentivo e estímulo para a realização deste trabalho.

À seção de Imunologia do Instituto Adolfo Lutz, onde foram realizados os experimentos, à todos que direta ou indiretamente contribuíram para realização deste trabalho.

Aos meus colegas Andréia, Simone, André e Verônica pela amizade, apoio e contribuição. 
"Comece fazendo o que é necessário, depois o que é possível, e de repente você estará fazendo o impossível".

(São Francisco de Assis) 


\section{RESUMO}

Neisseria lactamica, uma bactéria comensal não patogênica, predominantemente humana e usualmente encontrada no trato respiratório superior de crianças, está intimamente relacionada a Neisseria meningitidis patogênica. A colonização com $N$. lactamica pode ser responsável pelo envolvimento da imunidade natural contra a infecção pelos meningococos em crianças pequenas, quando as taxas de portadores de meningococos são baixas. Estas características levam a sugerir que os componentes de $N$. lactamica possam ser um elemento-chave para a produção de uma nova vacina para $N$. meningitidis. Devido ao pouco conhecimento sobre a dinâmica dos portadores e sobre a diversidade da população de $N$. lactamica em crianças, tem sido difícil escolher um isolado representativo para preparar um adequado produto imunogênico. Em nosso estudo, foi proposto um protocolo para estudar a imunogenicidade de whole cells de $N$. lactamica, $N$. meningitidis, $N$. sicca ou $N$. meningitidis $c$ (isoladas de portadores), através da imunização intranasal em coelhos, considerando a via de entrada natural do patógeno. Isolados da orofaringe de $N$. lactamica, $N$. meningitidis, $N$. sicca ou $N$. meningitidis $c$, foram inoculados em coelhos adultos pela via intranasal, numa concentração de densidade ótica 1.0 a 650nm, num volume de $1000 \mu \mathrm{L}$. Os coelhos foram imunizados por quatro vezes em intervalos de sete dias. Também foram usadas cepas como $N$. subflava, $N$. elongata, $N$. sicca, $N$. perflava, N. mucosa isoladas do líquido cérebro-espinhal ou sangue de pacientes. Os coelhos desenvolveram níveis de anticorpos IgG específicos no soro, como foi determinado por ELISA usando whole cells de cepas homólogas e heterólogas. O soro dos coelhos imunizados com N. lactamica, N. meningitidis, N. sicca ou N. meningitidis $c$, apresentaram anticorpos IgG que reagiram com antígenos numa faixa de 5 a $130 \mathrm{kDa}$ por meio de immunoblot. Os anticorpos presentes nos soros dos coelhos imunizados com $N$. lactamica não induziram altos títulos de anticorpos com atividade bactericida contra as cepas de $N$. meningitidis, no entanto, esta atividade pode ser observada com anticorpos produzidos pelos coelhos imunizados intranasalmente com $N$. meningitidis. Anticorpos IgG de alta avidez foram produzidos, embora não tenha sido determinada uma significativa correlação entre atividade bactericida e a indução de anticorpos IgG de alta avidez, principalmente nos coelhos imunizados com N. lactamica. A imunização 
intranasal usando whole cells de $N$. lactamica foi adequada para sensibilizar eficientemente o sistema imune de mucosa no modelo coelho. 


\section{ABSTRACT}

Neisseria lactamica, a commensal bacterium non-pathogenic to human beings and usually found in the upper respiratory tract of children, is closely related to pathogenic Neisseria meningitides. Colonization with $N$. lactamica can be responsible for evolving natural immunity to meningococcal infection in childhood, when rates of meningococcus carriers are low. These features lead to suggest that $N$. lactamica components can be key-elements in the production of a new vaccine for $N$. meningitides. As little is known about dynamic carriers and $N$. lactamica population diversity in children, it has been difficult choosing a representative for preparing an adequate immunogenic product. $A$ protocol was proposed to study immunogenicity of whole cells of $N$. lactamica, $N$. meningitidis, $N$. sicca or $N$. meningitides $c$ (carrier-isolated) by i.n. immunization in rabbits considering the natural pathogen entry route. Oropharinx-isolated $N$. lactamica, $N$. meningitidis, $N$. sicca, or $N$. meningitides $c$ were i.n. inoculated into adult rabbits, in a concentration of optical density 1.0 at $650 \mathrm{~nm}$ in a volume of $1000 \mu \mathrm{L}$. The rabbits were immunized four times at seven-day intervals. $N$. subflava, $N$. elongata, $N$. sicca, $N$. perflava, $N$. mucosa strains isolated from CSF and blood from patients were also used. The rabbits developed levels of specific IgG antibodies in serum, as determined by ELISA using whole cells of homologous and heterologous strains. Serum from rabbits immunized with $N$. lactamica, $N$. meningitidis, and $N$. sicca or $N$. meningitides $c$, presented lgG antibodies reactive to 5 to $130 \mathrm{kDa}$ antigens on immunoblot. Antibodies in serum from rabbits immunized with $N$. lactamica failed to induce high concentration of antibodies with bactericidal activity against $N$. meningitidis; however, this activity could be observed with antibodies produced by rabbits i.n. immunized with $N$. meningitidis. High avidity IgG antibodies were produced, although a significant correlation between bactericidal activity and induction of IgG antibodies of high avidity could not be determined, mainly in rabbits immunized with $N$. lactamica. Intranasal immunization of $N$.lactamica whole cells was suitable to efficiently sensitize mucosal immune system in rabbit model. 


\section{LISTA DE FIGURAS}

FIGURA 1. Doença meningocócica: distribuição percentual por sorogrupo Estado de SP, 1990-2004.

FIGURA 2. Doença meningocócica: incidência e letalidade no Estado de São Paulo, 1990-2004.

FIGURA 3. Doença Meningocócica: coeficientes de incidência (por 100.000 hab.), segundo faixa etária, Estado de são Paulo, 1995 a 2003.

FIGURA 4. Perfil eletroforético de suspensão de células bacterianas integras (whole cells) de $N$. meningitidis e bactérias do gênero Neisseria e NOMV da cepa de $N$. menigitidis.

FIGURA 5. Géis (A e B) do Blot MAb 8c7Br1

FIGURA 6. (A) Estudo da produção de anticorpos IgG presentes no soro de coelhos imunizados com quatro doses de $N$. lactamica pela via intranasal. Reatividade com $N$. meningitidis e cepas do gênero Neisseria. Reatividade com as cepas (NM), (NL) (NS) e (NMc).

(B) Resultados da razão $\mathrm{DO} /$ média da recíproca dos títulos de anticorpos IgG contra antígenos de NM, NL, NS e MMc.

FIGURA 7. (A) Estudo da produção de anticorpos IgG presentes no soro de coelhos imunizados com duas doses de N. lactamica e duas doses de Neisseia lactamica pela via intranasal. Reatividade com $N$. meningitidis e cepas do gênero Neisseria. Reatividade com as cepas (NM), (NL) (NS) e (NMc).

(B) Resultados da razão DO/média da recíproca dos títulos de anticorpos IgG contra antígenos de NM, NL, NS e MMc.

FIGURA 8. (A) Estudo da produção de anticorpos IgG presentes no soro de coelhos imunizados com quatro doses de $N$. sicca pela via intranasal. Reatividade com $N$. meningitidis e cepas do gênero Neisseria. Reatividade com as cepas (NM), (NL) (NS) e (NMc).

(B) Resultados da razão $\mathrm{DO} /$ média da recíproca dos títulos de anticorpos IgG contra antígenos de NM, NL, NS e MMc.

FIGURA 9. (A) Estudo da produção de anticorpos IgG presentes no soro de coelhos imunizados com duas doses de $N$. sicca e duas doses de $N$. meningitidis $B$ pela via intranasal. Reatividade com $N$. meningitidis e cepas do gênero Neisseria. Reatividade com as cepas (NM), (NL) (NS) e (NMc).

(B) Resultados da razão $\mathrm{DO} /$ média da recíproca dos títulos de anticorpos IgG contra antígenos de NM, NL, NS e MMc.

FIGURA 10. (A) Estudo da produção de anticorpos IgG presentes no soro de coelhos imunizados com quatro doses de $N$. meningitidis $C$ isolada de carreador pela via intranasal. Reatividade com $N$. meningitidis e cepas do gênero Neisseria. Reatividade com as cepas (NM), (NL) (NS) e (NMc).

(B) Resultados da razão DO/média da recíproca dos títulos de anticorpos IgG contra antígenos de NM, NL, NS e MMc. 
FIGURA 11. (A) Estudo da produção de anticorpos IgG presentes no soro de coelhos imunizados com duas doses de $N$. meningitidis isolada de carreador e duas doses de $N$. meningitidis pela via intranasal. Reatividade com $N$. meningitidis e cepas do gênero Neisseria. Reatividade com as cepas (NM), (NL) (NS) e (NMc).

(B) Resultados da razão $\mathrm{DO} /$ média da recíproca dos títulos de anticorpos IgG contra antígenos de NM, NL, NS e MMc.

FIGURA 12. (A) Estudo da produção de anticorpos IgG presentes no soro de coelhos imunizados com quatro doses de $N$. meningitidis B pela via intranasal. Reatividade com N. meningitidis e cepas do gênero Neisseria. Reatividade com as cepas (NM), (NL) (NS) e (NMc).

(B) Resultados da razão $\mathrm{DO} /$ média da recíproca dos títulos de anticorpos IgG contra antígenos de NM, NL, NS e MMc.

FIGURA 13. (A) Estudo da produção de anticorpos IgG presentes no soro de coelhos imunizados com duas doses de $N$. meningitis e duas doses de $N$. lactamica pela via intranasal. Reatividade com $N$. meningitidis e cepas do gênero Neisseria. Reatividade com as cepas (NM), (NL) (NS) e (NMc).

(B) Resultados da razão $\mathrm{DO} /$ média da recíproca dos títulos de anticorpos IgG contra antígenos de NM, NL, NS e MMc.

FIGURA 14. Reatividade do anticorpo monoclonal 8C7Br1 com cepas de $N$. meningidis e bactérias do gênero Neisseria

FIGURA 15. Reatividade por meio de immunoblot de anticorpos do isótipo IgG presente no soro de coelhos imunizados pela via intranasal com quatro doses de $\mathrm{N}$. lactamica

FIGURA 16. Reatividade por meio de immunoblot de anticorpos do isótipo IgG presente no soro de coelhos imunizados pela via intranasal com duas doses de $N$. lactamica e duas doses de N.meningitidis

FIGURA 17. Reatividade por meio de immunoblot de anticorpos do isótipo IgG presente no soro de coelho imunizados pela via intranasal com quatro doses de $N$. sicca.

FIGURA 18. Reatividade por meio de immunoblot de anticorpos do isótipo IgG presente no soro de coelhos imunizados pela via intranasal com duas doses de $N$. sicca e duas doses de N. meningitidis

FIGURA 19. Reatividade por meio de immunoblot de anticorpos do isótipo IgG presente no soro de coelho imunizados pela via intranasal com quatro doses de $N$. meningitidis $C$

FIGURA 20. Reatividade por meio de immunoblot de anticorpos do isótipo IgG presente no soro de coelho imunizados pela via intranasal com duas doses de $N$. meningitidis c e duas doses de $N$. meningitidis

FIGURA 21. Reatividade por meio de immunoblot de anticorpos do isótipo IgG presente no soro de coelho imunizados pela via intranasal com quatro doses de $N$. meningitidis

FIGURA 22. Reatividade por meio de immunoblot de anticorpos do isótipo IgG presente no soro de coelho imunizados pela via intranasal com duas doses de N. meningitidis e duas doses de $N$. lactamica. 
TABELA 1. Esquema experimental de imunização de coelhos

TABELA 2. Cepas de gênero Neisseria isoladas do sangue, LCR ou Orofaringe durante os anos de 1990-2000 na Seção de Bacteriologia do Instituto Adolfo Lutz.

TABELA 3. Esquema experimental de imunização de coelhos

TABELA 4. Avaliação da avidez dos anticorpos

TABELA 5. Índice de aumento da reatividade apresentado por anticorpos dos isótipos IgG por meio de ELISA, em coelhos imunizados com whole cells de $N$. meningitidis e whole cells de bactérias do gênero Neisseria pela via intranasal

TABELA 6. Índice de avidez de anticorpos dos isótipos IgG no soro de coelhos imunizados pela vias intranasal para $N$. meningitidis

TABELA 7. Antígenos reconhecidos por anticorpos IgG produzidos após imunização nasal de coelhos.

TABELA 8. Títulos de atividade bactericida dos soros de coelhos imunizados pela via intranasal 35 dias após imunização 


\section{LISTA DE ABREVIATURAS}

AcM: anticorpo monoclonal

AEC: 3-amino-9-ethylcarbazole

[Al(OH) $\left.)_{3}\right]$ : Hidróxido de alumínio

APC: Células apresentadoras de antígenos

B4: leucotrienos

B7-1 e B7-2: Receptores de linfócitos

BALT: Tecido Linfóide associado ao broncoepitélio

BHI: "Brain Heart Infusion agar"

"Blebs": Estrutura vesiculares na membrana externa do microrganismo

Blot: "Immunoblotting" ou "Immunoblot"

BPI: proteína de aumento da permeabilidade bactericida

BSA: Soro Albumina Bovina

C1q, C3, C3b, C5, C6, C7, C8: componentes da cascata do sistema complemento

CD: "cluster" de diferenciação

CD4: receptor para MHC de classe II

CD8: receptor para $\mathrm{MHC}$ de classe I

CEACAM1: células de adesão

cm: centímetro

CNBr: Brometo de cianogênio

$\mathrm{CO}_{2}$ : dióxido de carbono

CR3: receptor de linfócito

CSF: Cerebral Spinal Fluid 
CTL: citotoxidade celular

CTLA: Ligantes de linfócitos T

DIC: doença invasiva crônica

dLOS: Lipooligossacáride detoxificado

DM: doença meningocócica

DNA: Ácido desoxirribonucléico

DO: Densidade Óptica

DTP: Vacina Difteria, Tétano e Coqueluche

EDDHA: ethylenediaminedihy-droxyphenylacetic

ELISA: "Enzyme linked immunosorbent assay"

E. coli: Escherichia coli

ET5, ET37: linhagens das cepas hipervirulentas de N. meningitidis

EUA: Estados Unidos da América

FAE: Epitélio folículo-associado

Fbp: "Ferric binding protein"

Fc: porção da imunoglobulina G

FcRII, FcRIII: receptores de linfócitos

FITC: isoticionato de fluoresceína

FMS: sepsis meningocócica fulminante

FRP: Iron restriction protein

g: constante de gravitação, quando referente à força gravitacional atuante na centrífuga

g: gramas, quando referente ao peso de reagentes e soluções

GALT: Tecido linfóide associado ao intestino

GIT: trato gastrointestinal 
GM1: glicolipídios monosiaologangliosídeos

GNA 33, GNA2132: Lipoproteínas que se expressam na superfície de cepas de $N$. meningitidis.

$\mathrm{H}_{2} \mathrm{O}_{2}$ : peróxido de hidrogênio

$\mathrm{H}_{2} \mathrm{SO}_{4}$ : ácido sulfúrico

H8 : lipoproteína

HA: Hidróxido de alumínio

HBV: Vacina Hepatite B

HCl: ácido clorídrico

Hib: Haemophilus influenzae $B$

$\mathrm{HOCl}$ : acido hipoclorídrico

HV1 e HV2: Regiões hipervariáveis nas seqüências de aminoácidos

IA: Índice de avidez de anticorpo

IAL/ SP: Instituto Adolfo Lutz/ São Paulo

ICAM-1: moléculas de adesão endoteliais

IFN: Interferon

IgA: Imunoglobulina de isótipo A

IgA-S: IgA secretória

IgG: Imunoglobulina de isótipo G

IgG1, IgG2, IgG3: Subclasses de imunoglobulina de isótipo G

IgM: Imunoglobulina de isótipo M

IL: Interleucina

i.m.: Via intramuscular

IRPS: "Iron Regulated Proteins" 
kDa: Kilodalton

kDO: 2-ceto-3-desoxi-D-octanato

KSCN: Tiocianato de Potássio

LALT: tecido linfóide associado à laringe

Laz: proteína anaeróbicamente induzida

Lbp: "Lactoferrin binding protein"

LCR: Líquido céfalo-raquidiano

Log: Logarítmo

LOS: Lipooligossacáride

LP2086: Lipoproteína 2086

LPS: Lipopolissacáride

M: Molar

Mab 8C7Br1: anticorpo monoclonal 8C7Br1

MALT: tecido linfóide organizado

MASP: protease serina

MBL: Manose Binding Lectin

MC58: Tipo de cepa de N. meningitidis

MCC: clearence mucociliar

MCP: membrane cofator protein

MF59: Monofosforil 59

$\mu g$ : micrograma

mg: miligramas

MHC: Complexo de Histocompatibilidade Principal 
MHC-I: Complexo de Histocompatibilidade Principal - I

MHC-II: Complexo de Histocompatibilidade Principal - II

$\mu \mathrm{L}$ : microlitro

$\mathrm{mL}$ : mililitro

MLEE: multilocus enzyme electrophoresis

MLST: multilocus sequence typing

mM: milimolar

MPL: Monofosforil Lípide A

NM: Neisseria meningitidis

NMc: Neisseria meningitidis isolada da orofaringe de carreador

Nm: Neisseria mucosa

NL: Neisseria lactamica

NS: Neisseria sicca

NSP: Neisseria subflava perflava

NE: Neisseria elongata

NF: Neisseria flava

NP: Neisseria perflava

NadA: proteína oligomérica de superfície de N. meningitidis.

$\mathrm{NAD}(\mathrm{P}) \mathrm{H}$ : adenina difosfato oxidase

NALT: Tecido Linfóide associado à nasofaringe

$\mathrm{N}$ : Normalidade (Normal)

Nac Glc: N-acetil-glicosamina

N-CAM: molécula de adesão neuronal 
$\mathrm{NaHCO}_{3}$ : carbonato de sódio

NaCl: cloreto de Sódio

NspA: "Neisserial surface protein A"

NOMV: "Native Outer Membrane Vesicles"

NT: Não tipável

nm: nanômetro

$\left(\mathrm{O}_{2}^{-}\right)$: anion superóxido

$\left({ }^{1} \mathrm{O}_{2}\right)$ oxigênio single

$\left(\mathrm{OH}^{-}\right)$: radicais hidroxila

OMC: "Outer membrane complex"

OMP: "Outer membrane proteins"

OMV: "Outer membrane vesicles"

Opa: "Opacity Associated protein"

Opc: "Outer membrane protein class 5C"

"overnight": período de aproximadamente 18 horas

p/v: relação peso/ volume entre soluto e solvente em uma solução

PAGE: "Polyacrylamide gel electrophoresis"

PAI-1: fator inibidor - ativador de plasminogenio 1

Pan 1: proteínas de transporte cápsular

PBS: Solução tamponada salina fosfatada

PCR: Polymerase Chain Reaction

pH: potencial hidrogeniônico

PilT: proteína envolvida na adesão às células epiteliais

PM: Peso molecular 
PMNL: polimorfonucleares

plgR: Receptor de imunoglobulina

Por: Porina

Polya 2-8 NeuNAc: Resíduo homopolímero de ácido N-acetil neuramínico.

PP: placas de Peyer`s

PS: polissacárides purificados

RAPD: random amplification of polymorphic DNA

RF: "Relative front" (migração relativa)

RFLP: Restriction Fragment Length Polymorphisms

RMP: "Reduction-modifiable protein"

SBA: atividade bactericida

SC: componente secretório

SCID: Severe Combined Immunodeficiency

SDS: dodecil sulfato de sódio

SDS-PAGE: eletroforese em gel de poliacrilamida

SELDI - MS: surface-enhanced laser desorption ionization mass spectrometry

slgA: IgA secretora

slgM: IgM secretória

SNC: Sistema nervoso central

SV: Regiões semi-variáveis nas seqüências de aminoácidos

T-0: Tempo Zero (referente a 100\% de crescimento bacteriano no ensaio bactericida)

Tbp: "Transferrin binding protein"

TCD4 : receptor de linfocitos $T$ 
$\mathrm{T}\left(\mathrm{CD} 45 \mathrm{RB}^{\text {high }}\right)$ : antígeno comum de leucócitos

TCD8: receptor de linfocitos $T$

TF: fator tecidual

Th: Linfócito T-helper

Th1/ Th2: Linfócito T-helper 1 ou 2, determinados por citocinas

TMB: Tetrametilbenzidina

TNF- $\alpha$ : Fator de Necrose Tumoral

TPA: fator ativador de plasmingogênio

Tris: (hidroximetil) aminometano

TSB: "Tryptic Soy Broth"

UFC: Unidades formadoras de colônias.

UspA2: adesina oligomérica de alto peso molecular

v/v: Relação volume do soluto e volume do solvente em uma solução

V: Volts

VR1, VR2, VR3 e VR4: Regiões variáveis nas seqüências de aminoácidos

wc: "whole-cells" (suspensão de células bacterianas íntegras)

YadA: adesina oligomérica de alto peso molecular 


\section{SUMÁRIO}

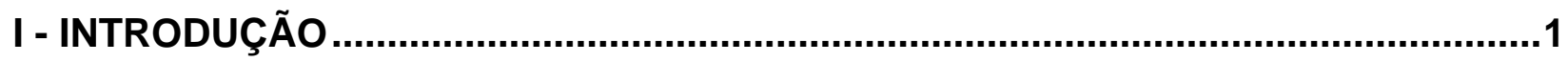

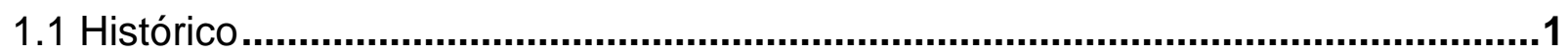

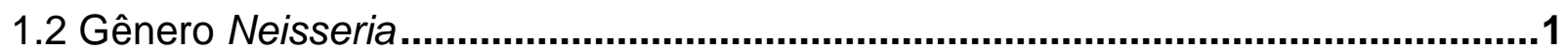

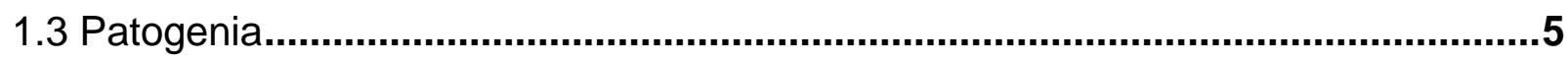

1.4 Colonização da mucosa nasofaríngea................................................................

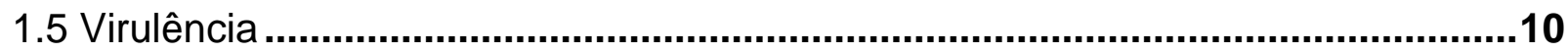

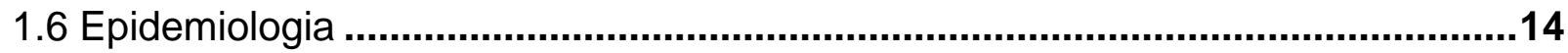

1.6.1 Prevalência de N. meningitidis e espécies de Neisserias comensais relatadas em humanos ................................................................................................21

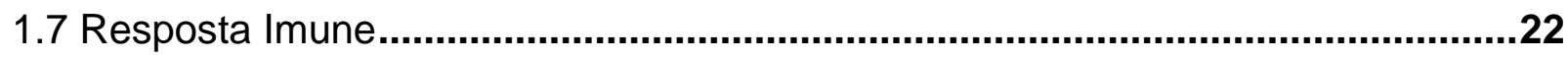

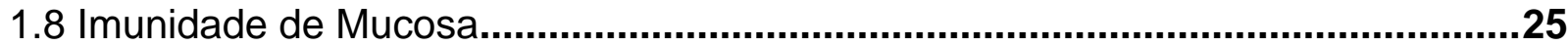

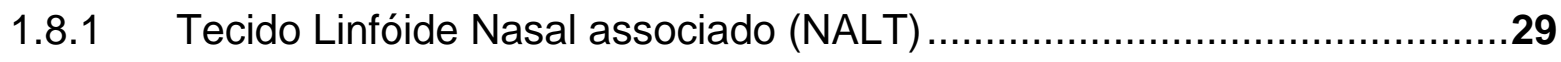

1.8.2 Administração de vacinas pela via de mucosa nasal ................................30

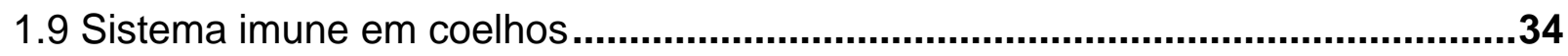

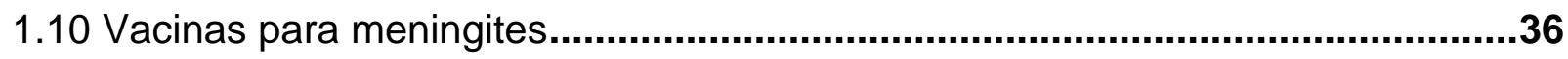

1.11 Vacinas atuais em desenvolvimento para o sorogrupo $B$................................41

1.11.1 Vacinas Propioniladas Conjugadas .........................................................

1.11.2 Vacinas de Proteínas de Membrana Externa (OMP) e Vesículas de

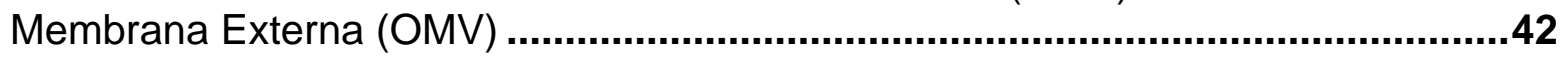

1.11.3 Vacinas baseadas em um antígeno universal ..........................................45

1.11.4 Vacinas baseadas na imunidade cruzada com outras Neisserias ............47

1.11.5 Vacinas compostas de OMVs de N. lactamica ................................................... 48

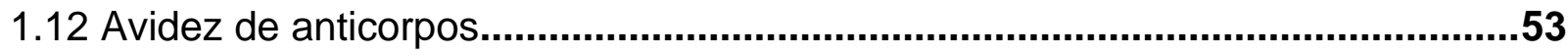

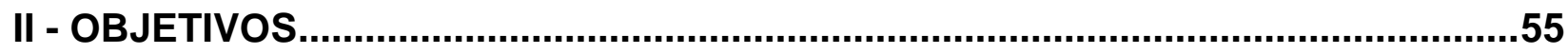

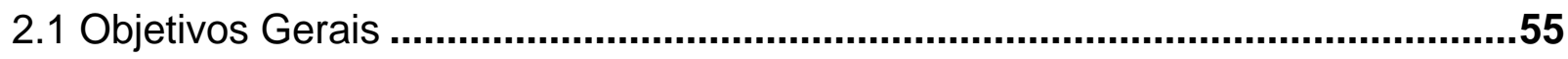

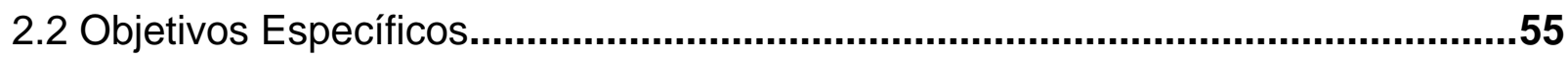




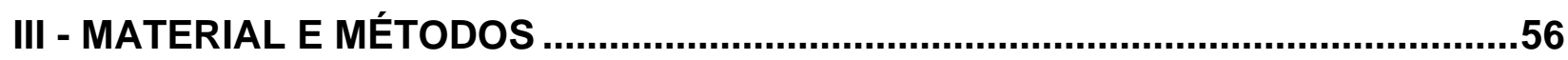

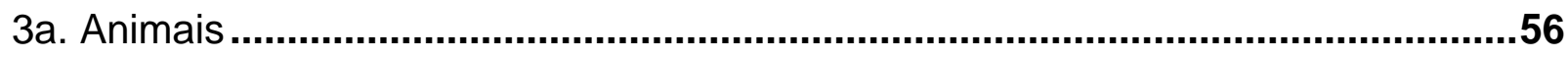

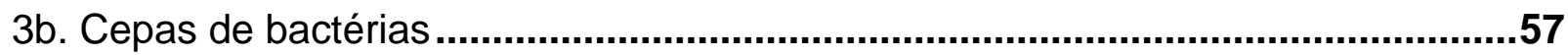

3c. Preparo da suspensão de células bacterianas íntegras de N. meningitidis e dos gêneros Neisseria("whole-cells") .................................................................................58

3d. Obtenção de anticorpos policlonais anti- N. meningitidis....................................59

3e. Eletroforese em gel de poliacrilamida (SDS-PAGE) ............................................59

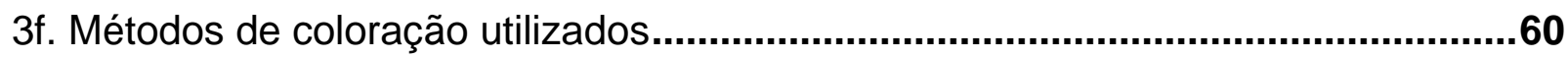

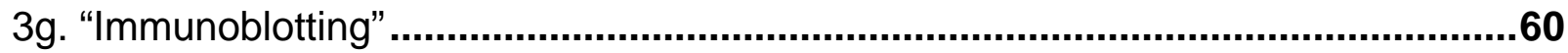

3h. ELISA

3i. Determinação do índice de avidez dos anticorpos................................................62

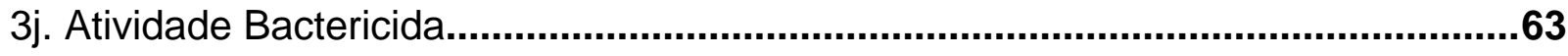

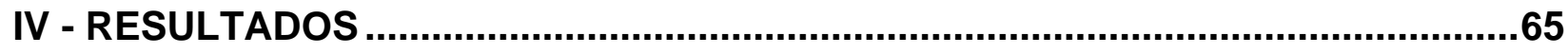

4a- Caracterização imunoquímica das preparações antigênicas utilizadas.................65

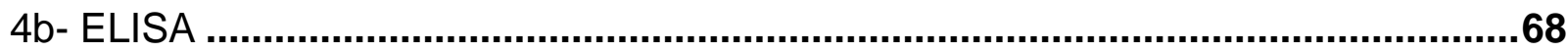

4.b.1. Reatividade de anticorpos do isótipo IgG presente nos soros de coelhos imunizados pela via intranasal com quatro doses de whole cells de N. lactamica..68

4.b.2. Reatividade de anticorpos dos isótipos IgG presente no soro de coelho obtido no 45 dia após imunização pela via intranasal com duas doses de whole cells de N. lactamica e duas doses de whole cells de N.meningitidis

4.b.3. Reatividade de anticorpos do isótipo IgG presente no soro de coelho imunizado pela via intranasal com quatro doses de whole cells de $\mathrm{N}$. sicca

4.b.4. Reatividade de anticorpos dos isótipos IgG presente no soro de coelho obtido no 45 dia após imunização pela via intranasal com duas doses de whole cells de N. sicca e duas doses de whole cells de N.meningitidis

4.b.5. Reatividade de anticorpos do isótipo IgG presente no soro de coelho imunizado pela via intranasal com quatro doses de whole cells de $N$. meningitidis c no $45^{\circ}$ dia após imunização. 
4.b.6. Reatividade de anticorpos dos isótipos IgG presente no soro de coelho obtido no 45 dia após imunização pela via intranasal com duas doses de whole cells de $N$. meningitis $c$ e duas doses de whole cells de N.meningitidis .

4.b.7. Reatividade de anticorpos do isótipo IgG presente no soro de coelho imunizado pela via intranasal com quatro doses de whole cells de N. meningitidis 81

4.b.8. Reatividade de anticorpos dos isótipos IgG presente no soro de coelho obtido no 45 dia após imunização pela via intranasal com duas doses de whole cells de $N$. meningitis e duas doses de whole cells de N.lactamica .

4c. Determinação do índice de avidez dos anticorpos IgG nos soros dos coelhos imunizados pela via intranasal

4d. IMMUNOBLOTTING.

4.d.1. Reatividade por meio de immunoblot de anticorpos do isótipo IgG presente no soro de coelho imunizado pela via intranasal com quatro doses de N. lactamica

4.d.2. Reatividade por meio de immunoblot de anticorpos do isótipo IgG presente no soro de coelho imunizado pela via intranasal com duas doses de $N$. lactamica e duas doses de $N$. meningitidis

4.d.3. Reatividade por meio de immunoblot de anticorpos do isótipo IgG presente no soro de coelho imunizado pela via intranasal com quatro doses de N. sicca.....91

4.d.4. Reatividade por meio de immunoblot de anticorpos do isótipo IgG presente no soro de coelho imunizado pela via intranasal com duas doses de $N$. sicca e duas doses de N. meningitidis .

4.d.5. Reatividade por meio de immunoblot de anticorpos do isótipo IgG presente no soro de coelho imunizado pela via intranasal com quatro doses de $N$.

meningitidis $C$

4.d.6. Reatividade por meio de immunoblot de anticorpos do isótipo IgG presente no soro de coelho imunizado pela via intranasal com duas doses de $N$. meningitidis c e duas doses de N. meningitidis.

4.d.7. Reatividade por meio de immunoblot de anticorpos do isótipo IgG presente no soro de coelho imunizado pela via intranasal com quatro doses de $N$. meningitidis

4.d.8. Reatividade por meio de immunoblot de anticorpos do isótipo IgG presente no soro de coelho imunizado pela via intranasal com duas doses de N. meningitidis e duas doses de $N$. lactamica .................................................................................96

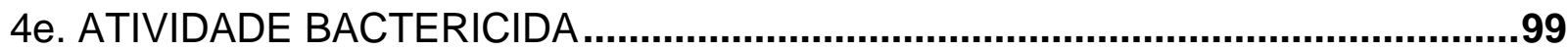

4.e.1. Atividade bactericida de coelhos imunizados pela via nasal.....................99 
V - DISCUSSÃO . 101

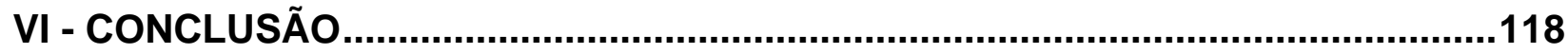

VII - REFERENCIAS BIBLIOGRÁFICAS

VIII - ANEXOS 


\section{I - INTRODUÇÃO}

\subsection{Histórico}

Os principais sinais e sintomas clínicos da doença meningocócica foram descritos primeiramente por Vieusseaux em 1806, e o microrganismo causador desta doença foi identificado por Weichselbaum em 1887. A bactéria foi inicialmente chamada de Diplococcus intracellularis e posteriormente passou a ser inserida no gênero de Neisseria (Fredlund, 1993).

No começo do século $X X$ foram identificados vários tipos de espécies de meningococos e essa grande heterogeneidade levou a um sistema de classificação subdividindo-as em sorogrupos, sorotipos e subtipos (Vedros, 1989). Assim, a classificação quanto aos sorogrupos, foi em função da natureza imunoquímica da cápsula bacteriana (Frasch et al., 1985).

\subsection{Gênero Neisseria}

Neisseria meningitidis é uma espécie bacteriana do gênero Neisseria que são estritamente patogênicas em humanos (Griffiss \& Artenstein, 1976). As Neisserias são diplococos Gram-negativos e aeróbios, oxidases positivas, produzem ácidos a partir da glicose, maltose e lactose, mas não da sacarose (Stuart et al., 1987). N. meningitidis define-se pela produção de ácido a partir dos carboidratos glicose e maltose, enquanto que o consumo de lactose juntamente com glicose e maltose define Neisseria lactamica, diplococo Gram-negativo não capsulado, não patogênico, comumente encontrado na nasofaringe de crianças, nos primeiros anos de vida (Requejo, 1996). A identificação de $N$. lactamica pode ser confirmada pela detecção da beta-galactosidase em um teste de enzima-substrato (Bovre, 1984).

Devido as espécies de Neisseria comensais raramente crescerem em meio seletivo usado para isolar gonococos e meningococos, a prevalência destas espécies pode ser determinada em um meio de cultura que não contenha colistina, um antibiótico incorporado no meio seletivo para meningococos e gonococos que tem a finalidade de inibir o crescimento de espécies comensais. Outras espécies de Neisseria ( $N$. subflava, N. perflava, N. elongata, N. sicca, N. mucosa), são identificadas pelos testes de 
detecção de ácido a partir da utilização de carboidratos e também pelos testes de enzima-substrato. Alguns testes realizados usam meio diferencial e seletivo que inibem o crescimento de espécies que não Neisserias e seleciona as espécies comensais de Neisseria pela diferenciação entre espécies assacarolíticas ou entre os vários diferentes grupos de espécies (Knapp, 1988).

As Neisserias crescem bem em meio à base de ágar-sangue, ágar triptose-soja, ágar-chocolate e ágar Mueller-Hinton a $37^{\circ} \mathrm{C}$ em atmosfera de $5 \%$ de $\mathrm{CO}_{2}$. Em meio sólido as colônias são convexas, transparentes, não-pigmentadas, não-hemolíticas, com aproximadamente 1 a $5 \mathrm{~mm}$ de diâmetro. Os meningococos são usualmente isolados do sangue, fluido cérebro espinhal (LCR), nasofaringe e / ou através de culturas e ocasionalmente de exudatos bem como de outros espécimes. A coloração de Gram mostra diplococos Gram-negativos (Fredlund, 1993).

O desenvolvimento de técnicas que permitem a diferenciação e classificação das estruturas bacterianas dos meningococos é de suma importância no conhecimento de diferentes cepas que efetivamente causam doença, além disso, auxilia no conhecimento filogenético, bem como na dispersão geográfica das cepas meningocócicas que são essenciais para o preparo de novas vacinas. Além dos métodos padrão utilizados para o diagnóstico dos meningococos, também é possível a utilização de técnicas imunológicas (Fredlund, 1993). A sorogrupagem do meningococo é feita normalmente pela reação de aglutinação, a sorotipagem e a subtipagem são feitas principalmente pelo método de "Dot-blotting" (Frasch, 1995), podendo-se também empregar o "immunoblotting" e a contra-imunoeletroforese (Poolman et al., 1982; Davies et al., 1990; De Gaspari, 2000a). Há cerca de vinte anos vêm sendo utilizados métodos como o multilocus enzyme electrophoresis (MLEE), random amplification of polymorphic DNA (RAPD), polymerase chain reaction (PCR), restriction fragment length polymorphisms (RFLP), e multilocus sequence typing (MLST) (Maiden et al., 1998). Entre estes métodos o MLEE e MLST têm sido considerados os "padrões ouro" para o estudo da epidemiologia dos meningococos, sendo o MLEE uma poderosa técnica para distinguir vários clones de meningococos (Caugant, 1998).

Dois métodos para avaliar a resposta humoral aos meningococos são amplamente utilizados, enzyme linked immunosorbent assay (ELISA) mede a 
concentração de anticorpos no soro contra meningococos íntegros ou constituintes da superfície do microrganismo, particularmente polissacárides ou proteínas de membrana externa. $O$ ensaio de atividade bactericida mede a quantidade de anticorpos presentes no soro contra a bactéria que é sensivel pela ação lítica mediada pelo complemento exógeno. O titulo de anticorpos bactericidas correlaciona-se com a proteção contra o meningococo, no entanto, não está claro ainda se somente o título de anticorpos bactericidas no soro está correlacionado com a proteção contra os meningococos (Pollard \& Levin, 2000). Estudos sugerem que a proteção contra a infecção causada pelo meningococo sorogrupo $B$ seja devido também a anticorpos com atividade de opsonofagocitose bem como pela resposta imune inata, as quais não são demonstradas pelos testes de atividade bactericida (Vermont \& van den Dobbelsteen, 2003). Atualmente os ensaios que demonstram atividade opsonofagocítica sugerem serem em os mais apropriados marcadores de proteção do que a atividade bactericida no caso do sorogrupo B (Vermont \& van den Dobbelsteen, 2003). O ensaio da atividade opsonofagocítica é desenvolvido utilizando células fagocíticas polimorfonucleares (PMNL) juntamente com anticorpos do soro e opsonização pelo complemento e a ingestão de antígenos ligados a beads fluorescentes ou meningococos fixados com etanol e marcados com isoticionato de fluoresceína (FITC), após a qual a fagocitose pode ser quantificada por citometria de fluxo, quimioluminescência ou pela medida da atividade do "burst" oxidativo. A bactéria coberta com FITC pode destruir a conformação do epítopo e, portanto, não refletir a exposição do epítopo sobre a bactéria viva (Michaelsen et al., 2001). No entanto antígenos cobertos com beads provavelmente apresentam serem similares à conformação nativa e tem a vantagem de poder se estudar melhor a especificidade da atividade opsonofagocítica do soro (Lehmann et al., 1999). A atividade opsonofagocítica do soro tem demonstrado correlação com títulos IgG contra OMVs, Por A e Por B medida por meio do ensaio de (ELISA) e pela atividade bactericida (SBA) (Aase et al., 1995). A medida da atividade opsonofagocítica pode ser uma avaliação adicional para a triagem de vacinas (Vermont $\&$ van den Dobbelsteen, 2003).

Hoje, a classificação de $N$ meningitidis é baseada no polissacáride capsular, proteínas de membrana externa (OMP), lipopolissacárides (LPS) ou lipooligossacárides 
(LOS) (Fredlund, 1993). Com base nos antígenos capsulares, são conhecidos 12 sorogrupos designados: A, B, C, X, Y, Z, W-135, 29E, H, I, K e L, esses sorogrupos se distinguem pela estrutura química de seus polissacárides capsulares (Frasch et al., 1985). Algumas cepas são não-grupáveis, uma vez que não são reconhecidos antígenos polissacárides capsulares (Craven et al., 1982). As cápsulas das cepas do sorogrupo B e C são homopolímeros de ácido siálico ligado a a 2,8 e a 2,9 respectivamente. Os outros são copolímeros de ácido siálico e monossacarídeos que estão ligados à glicose no caso do grupo $\mathrm{Y}$ ou galactose no caso do W135 (Peltola, 1998).

A membrana externa do meningococo contem 3 a 5 proteínas majoritárias divididas em 5 classes estruturais que aparentemente estão correlacionadas com seus pesos moleculares definidos em gel de poliacrilamida (SDS-PAGE) de 46, 41, 38, 33 e 28 kDa, e são classificadas em classes 1, 2, 3, 4 e 5, respectivamente (Tsai et al., 1981; Poolman, 1995). Os sorotipos e subtipos são definidos tomando-se com base a diferença dessas OMPs. A sorotipagem é feita baseando-se na diferença das proteínas de classe $2 / 3$ e o subtipo é determinado pela diferença da proteína de classe 1 . As cepas dos meningococos nunca expressam as proteínas de classe 2 e 3 simultaneamente. Estas proteínas funcionam como porinas e controlam o fluxo de íons na bactéria. $O$ imunotipo é determinado pela diferença na estrutura oligossacáridica do LPS (Zollinger et al., 1991a; Moran et al., 1994). Pelas técnicas desenvolvidas até hoje foram analisados 12 imunotipos de L1 a L12 (Zollinger et al., 1991a; Verheul et al., 1993). Os imunotipos de meningococos são definidos mais precisamente a partir da estrutura de seus oligossacárides. Esses oligossacárides são componentes dos lipopolissacárides situados na membrana externa formando um núcleo de açúcares dentro dos lipopolissacarídeos (Verheul et al., 1993).

Todos os meningococos compartilham vários determinantes antigênicos, especialmente com outras espécies de Neisseria como a $N$. lactamica, $N$. mucosa, $N$. sicca, N. flavences, N. subflava, N. perflava, N. flava (Bovre, 1984; Vedros, 1984; Knapp, 1988), mas também com espécies diferentes como Escherichia coli K1, K2 e K64 (Kasper et al., 1973), Bacillus pumilis (Robbins et al., 1972) e Streptococcus faecalis (Griffiss et al., 1977). A variação antigênica presente em N. lactamica ainda não 
foi completamente esclarecida, e a dinâmica dos indivíduos e populações portadores ainda estão sendo estudados (Bennett et al., 2005).

A determinação da seqüência da alta variabilidade antigênica de nucleotídeos de $N$. lactamica fornece um meio de investigação mais rápido para compreender a diversidade e estrutura da população bacteriana, através da utilização da técnica de MLST (Maiden et al., 1998).

Estes estudos de diversidade genética podem melhorar o entendimento da biologia da população de $N$. lactamica e auxiliar na investigação do papel que a $N$. lactamica desempenha na indução da imunidade contra os meningococos e a escolha dos isolados destes componentes pode estar disponível para a inclusão de vacinas meningocócicas (Bennett et al., 2005). Como as N. lactamica são acapsuladas (Griffiss et al., 1987), esta imunidade pode ser ativa contra os componentes subcapsulares dos meningococos, e dada à diversidade antigênica e genética das populações de meningococos (Caugant, 1998), a proteção ativa induzida por $N$. lactamica pode também apresentar proteção cruzada contra muitas cepas de meningococos. Esta ampla proteção pode, por exemplo, ser uma conseqüência da exposição a cepas de $N$. lactamica, resultando em uma resposta imune de reatividade cruzada contra diferentes antígenos de meningococos. Alternativamente, a exposição a uma única cepa de $N$. lactamica pode resultar numa imunidade aos componentes celulares que são altamente conservados dentro do gênero Neisseria (Bennett et al., 2005).

\subsection{Patogenia}

N. meningitidis é um patógeno comensal do trato respiratório superior humano. O meningococo está presente na nasofaringe humana assintomaticamente em cerca de $30 \%$ em crianças e 5 a $10 \%$ em adultos em período não epidêmico. A colonização da nasofaringe é um importante processo de imunização que pode proteger contra uma futura doença. A despeito da alta taxa de portadores assintomáticos, a doença invasiva devido a esta bactéria é relativamente rara, sugerindo que são requeridas condições particulares para se estabelecer a infecção.

Recentes estudos indicam que fatores como virulência clonal bem como o aumento da susceptibilidade do hospedeiro devido a infecções respiratórias pode afetar 
o balanço entre o estado de portador e o desenvolvimento da doença (de Vries et al., 1996). Provavelmente as crianças pequenas que portam bactérias comensais no epitélio da nasofaringe, em especial $N$. Lactamica podem adquirir imunidade à $N$. meningitidis através de repetidas exposições aos antígenos de reatividade cruzada presentes nestes organismos (Morley \& Pollard, 2001).

A taxa de portadores de $N$. lactamica investigados em um estudo em diferentes países da Europa foram altas em jovens e crianças (12 - 65\%) comparada com adultos ( $2-5 \%$ ), isto demonstra que $N$. lactamica encontrada em crianças, e a associação com o desenvolvimento da imunidade à doença meningocócica parecem ser de grande importância em muitas comunidades (Braun et al., 2004).

As significativas diferenças na ligação de anticorpos a antígenos nas cepas isoladas de portadores de $\mathrm{N}$. lactamica de diferentes regiões da Europa indicam que as diferenças fenotípicas de isolados de N.lactamica podem contribuir para o desenvolvimento de diferentes padrões nas comunidades (Braun et al., 2004). A maioria dos isolados de $N$. lactamica de crianças e adultos testados, expressaram reatividade cruzada com imunotipo de meningococo $L(3,7,9)$ associado com a virulência de meningococos patogênicos, sugerindo que este fenótipo sobre as espécies comensais pode ser o antígeno mais envolvido no desenvolvimento da imunidade natural contra a doença meningocócica. Isto pode levar a grande susceptibilidade à doença meningocócica naquelas populações, por exemplo, que tem uma baixa proporção de cepas comensais que expressam os epítopos $L(3,7,9)$ ou $L 8$ (Braun et al., 2004).

Os meningococos são transmitidos pelo contato direto com secreções nasais ou orais ou mesmo através da inalação (Tzeng \& Stephens, 2000). Os mecanismos que produzem a sepsis e a meningite meningocócica envolvem: a penetração da bactéria no epitélio do trato respiratório superior, danos às células endoteliais, invasão da barreira hemato-encefálica, atingindo o sistema nervoso central e iniciação da cascata inflamatória (Brandtzaeg, 1992). A invasão da superfície mucosa é uma característica de bactérias patogênicas, a adesão pode iniciar um processo descrito por endocitose direta onde os organismos são internalizados pelas células epiteliais não-ciliadas, freqüentemente em vesiculas, de onde são transportados até a membrana mucosa 
(Stephens \& Farley, 1991). Os pili são as estruturas mais importantes da superfície do meningococodo que iniciam a ligação da bactéria às células epiteliais da mucosa nasofaringea. Os meningococos piliados se ligam aos microvilos das células nãociliadas da nasofaringe e sofrem endocitose por estas células (Stephens \& Farley, 1991).

A infecção meningocócica pode ser limitada à nasofaringe, apresentando somente sintomas locais ou assintomática, ou pode ocorrer a forma septicemica grave causando também outras manifestações clinicas, incluindo artrite séptica, pneumonia, pericardite purulenta, conjuntivites, otites, sinusites e uretrites. A doença é caracterizada por inicio súbito, apresentando sinais clínicos como calafrios, febre alta, náuseas, vômitos, dores pelo corpo, prostração e mal-estar, e, quando evolui para uma meningococcemia podem aparecer exantema patequial ou púrpuras hemorrágicas. $\mathrm{O}$ último estágio da doença é caracterizado pela síndrome de Waterhouse-Friederickson e falência múltipla de órgãos (Meyer et al., 1994; Rosenstein et al., 2001).

Vários parâmetros clínicos e laboratoriais, freqüentemente associados com um sistema de pontuação, têm sido estabelecidos como indicadores de prognóstico da doença meningocócica (Stiem \& Damrosch, 1966; Niklasson et al., 1971; Bjorvatn et al., 1984; Sinclair et al., 1987; Halstensen et al., 1987). Importantes fatores clínicos podem estar associados com a alta mortalidade estando incluídos a septicemia sem meningites, baixa pressão do sangue (choque), petéquias hemorrágicas, convulsões, hiperpirexia, baixa contagem de leucócitos, e extensiva coagulopatia. Uma alta concentração de endotoxina bacteriana tem sido correlacionada como um importante fator prognóstico de falência múltipla de órgãos e morte na doença meningocócica sistêmica (Waage et al., 1987; Brandtzaeg et al., 1989).

As crianças pequenas correm maior risco de adquirir a doença meningocócica, embora crianças menores de seis meses de idade parecem ter alguma proteção contra a doença, provavelmente devido à persistência de anticorpos maternos. A grande incidência, portanto, está entre crianças de seis a vinte e quatro meses de idade, havendo um declínio da incidência conforme aumenta a idade (Rosenstein et al., 1999). A diminuição da incidência da doença meningocócica depende do desenvolvimento de vacinas seguras e eficazes. Em 1969, Goldschneider descreve uma relação inversa da 
incidência da doença meningocócica e a presença de anticorpos bactericidas. A presença desses anticorpos está correlacionada com o estado de proteção. As estruturas presentes na membrana externa bacteriana dos meningococos são os primeiros antígenos a entrarem em contato com o hospedeiro durante o estado de portador. A investigação de estruturas de superfícies dos meningococos que induzem atividade bactericida poderá levar ao desenvolvimento de uma vacina eficaz (Goldschneider et al., 1969).

Uma vez que os meningococos alcançam a corrente sanguinea, diferentes manfestações podem ser desenvolvidas. Em alguns pacientes, provavelmente aqueles com baixo grau de bacteremia, os meningococos são evidenciados espontaneamente, deixando para trás a chamada meningococemia transitória caracterizada por um curto episódio de febre (Dashefsky et al., 1983; Shapiro et al., 1986; Sullivan \& LaScolea, 1987; Gedde-Dahl et al., 1990). Quando a bacteremia não está evidenciada, o desenvolvimento da doença está clinicamente em aberto. Nestes casos, a última apresentação clínica é determinada pelas propriedades bacterianas como a liberação de endotoxinas e pelas características apresentadas como o estado do sistema imune e possível resposta às endotoxinas. A endotoxina é liberada na forma de vesículas de membrana externa blebs consistindo de 50\% de LOS, e OMPs, lipídeos, e polissacarídeos capsulares (DeVoe \& Gilchrist, 1973). Durante a doença invasiva, estas estruturas podem ser visualisadas no plasma ou fluido cérebro-espinhal por microscopia eletrônica (Stephens et al., 1982; Brandtzaeg et al., 1992).

\subsection{Colonização Da Mucosa Naso-Orofaríngea}

Porque certas cepas colonizam a mucosa naso-orofaringea e outras não são caso de extensas pesquisas (Nassif \& So, 1995; Poolman, 1995; Meyer et al., 1999). A colonizaçao pode ocupar tanto a superfície exterior da mucosa como intra ou subepitelialmente. Os danos ao epitélio ciliado da nasofaringe pode ser o primeiro passo da colonização (Stephens et al., 1986; Rayner et al., 1995).

Danos físicos causados por fumantes ativos ou passivos aumentam o risco para a doença invasiva (Haneberg et al., 1983; Fischer et al., 1997), bem como eventos de estresse e infecções virais antecedentes as quais podem alterar a integridade da 
superfície mucosa ou influenciam o sistema imune (Haneberg et al., 1983; Cartwright et al., 1991; Raza et al., 1999).

Os pili são as maiores adesinas que contribuem para a adesão as células de mucosa. Estes filamentos de proteína glicosilada emanam como apêndices da superfície bacteriana, atravessam o polissacarídeo capsular e se ligam aos receptores das células da nasofaringe, isto é, ao cofator de proteína da membrana ou CD46 ligados a este receptor e traduz um sinal para as células efetoras (Virji et al., 1992; Kallstrom et al., 1997; Kallstrom et al., 1998).

Após a ligação primária, futuros contatos com as células efetoras são estabelecidos via OMPs de classe 5 (Opa e Opc). Opa liga a receptores carcinoembriônicos CD66 (Virji et al., 1996). A interação com estes receptores sobre as células fagocíticas e células endoteliais medeiam a fagocitose e a produção de citocinas (Meyer, 1999). A Opc se liga a receptores proteoglicanos heparan sulfato (de Vries et al., 1996). As ligações de ambos receptores estimulam o englobamento dos meningococos pelas células epiteliais. Interessantemente estes processos são retardados pela presença da cápsula ou do LOS (Stephens et al., 1993; Virji et al., 1995), fatores que são indispensáveis para a sobrevivência do meningococo na corrente sangüínea. Durante o estado de portador e invasão pelos meningococos, a expressão de pili, OMP de classe 5, cápsula e LOS são variáveis e sujeitos a switching e variação antigênica (Achtman et al., 1991; Jones et al., 1992; de Vries et al., 1996). Estes mecanismos podem ser usados pela bactéria para driblar o sistema de defesa imune (Poolman, 1995).

A invasão ou penetração dos meningococos em células epiteliais de mucosa ocorre via vacúolos fagociticos como resultado da endocitose. Durante a invasão, vários fatores bacterianos modulam o metabolismo das células de mucosa. Como mencionado acima, a ligação dos pili e as OMPs classe 5 ao seus receptores traduz um sinal para as células de defesa. PorB, uma classe $2 / 3$ de OMP, pode translocar dentro das membranas das células alvo e afetar a maturação dos fagossomos (Rudel et al., 1996). As proteases IgA1 são OMPs que inativam IgA1 específica (Mulks et al., 1978; Vitovski et al., 1999). Pela estimulação da degradação da glicoproteína de membrana em 
endossomos e lisossomos, elas também promovem a sobrevivência dos meningococos nas células epiteliais (Ayala et al., 1998).

Freqüentemente, a doença invasiva é precedida por infecções do trato respiratório causadas por Mycoplasma pneumoniae ou viral (virus da influenza A) sobre o trato respiratório. No entanto, precisa ser notado que estes estudos epidemiológicos podem ser confundidos, uma vez que as infecções do trato respiratório aumentam a transmissão mecânica dos meningococos através do espirro e tosse e então ele mesmo pode causar sinais de infecção do trato respiratório superior (Olcén et al., 1981).

\subsection{Virulência}

Os meningococos desenvolveram um sofisticado mecanismo de escape do sistema imune para competir com as bactérias comensais do trato respiratório superior humano e ocasionalmente invadir a circulação, dentre os quais podemos citar alguns componentes da membrana e da cápsula que estão envolvidos na adesão da bactéria à superfície dos tecidos podendo também participar de mecanismos antifagocitários e de inibição ou inativação do complemento (Vidarson et al., 2001). O fator de virulência melhor definido do meningococo está relacionado com a estrutura dos polissacárides capsulares, das proteínas de membrana externa e dos lipooligossacárides (Lee, 1987).

A cápsula polissacarídica propicia a entrada do microrganismo na circulação sanguínea, uma vez que cepas não-capsuladas são encontradas somente na nasofaringe de portadores assintomáticos e não no sangue, além de resistir à fagocitose mediada pelos neutrófilos, aumentando a sua virulência (Lee, 1987).

O meningococo se multiplica extracelularmente até que ocorra a produção de anticorpos específicos capazes de permitir a opsonização, neutralizando a ação antifagocítica do polissacáride (Faria \& Fahrat, 1999).

Cada sorogrupo de N. meningitidis é definido pelo seu polissacáride capsular o qual é sintetizado no citoplasma, provavelmente junto à membrana interna. Em meningococos possuidores de ácido siálico, por exemplo, uma enzima denominada sialil-transferase associada à membrana interna, dirige a polimerização do polissacáride (Frasch et al., 1976). O ácido siálico capsular é importante na resistência do microrganismo à lise mediada por complemento e apresentam mimetismo imunológico 
com estruturas idênticas aos componentes das células neuronais humanas, impedindo com isso a indução de anticorpos efetivos contra a bactéria (Vidarson et al., 2001).

Os oligossacárides meningocócicos, tais como os glicoesfingolipídios que envolvem os neurônios no cérebro apresentam na longa cadeia molecular, uma lacto-Nneotetrose, que é polisialilada na membrana dos neurônios. A sialilação é propriedade comum dos neurônios e dos meningococos B, C, Y e W135 e ocorre através da enzima sialil-tranferase, a qual pode utilizar o ácido siálico de origem humana e incorpora-los nos polissacárides meningocócicos (Kim et al., 1989). Os polissacárides capsulares meningocócicos são polímeros constituídos de unidades repetidas de oligossacárides, essas unidades podem ser homopolímeros lineares de uma substância única como no caso de $N$. meningitidis A, B e C ou heteropolímeros, como nos grupos sorológicos $\mathrm{Y}$ e W135 e podem apresentar grupamentos tais como O-acetil, $\mathrm{N}$-acetil, glicerol e ligações fosfatídicas (Lee, 1987).

Os lipooligossacárides (LOS) são um importante determinante do fator de virulência em $N$. gonorrhoeae e $N$. meningitidis. Os LOS de Neisserias contém três cadeias de oligossacarídeos, denominadas cadeias $\alpha, \beta$ e $\gamma$. Eles têm um importante glicolipídio de membrana externa envolvido no sistema de evasão imune, adesão ao tecido epitelial, invasão das células de defesa, mediadores de toxicidade e estimulação de anticorpos bactericidas (Arking et al., 2001b).

A biossíntese de LOS pelos meningococos e gonococos ocorre pela mesma via produtora de oligossacárides ligados ao lipídeo. A via duas moléculas de 3-deoxy-Dmanno-2-octulosonic acid (KDO) (Johnson et al., 1976; John et al, 1991; Gibson et al., 1993). A estrutura de LOS dos gonococos e meningococos mostram uma grande heterogeneidade entre as cepas, e a variação no número de componentes dos LOS expressos e a sua relativa concentração e composição das suas moléculas de açúcar são observadas (Mandrell et al., 1991; Pavliak et al., 1993; Lee et al., 1995) e a extensão de cada oligossacáride variam, e esta variação é importante na determinação do potencial patogênico expressos nas cepas (Arking, 2001b).

Adicionalmente, os meningococos e gonococos podem modificar seu LOS pela adição de um resíduo de acido siálico sobre o terminal galactose que é encontrado na estrutura lacto-N-neotetrose (Parsons et al., 1989). Esta adição faz com que a LOS 
mascare o reconhecimento do sistema imune, fazendo com que o organismo se torne resistente à morte mediada pelo complemento, ou seja, é soro-resistente (Parsons et al., 1989). Todas as espécies patogênicas encontradas possuem seqüências de DNA homólogas com o gene lgt cluster, do grupo de genes necessários para a síntese da cadeia $\alpha$. Alguns destes genes foram também encontrados em cepas consideradas não patogênicas como em N. lactamica, N. subflava, e N. sicca.

Um outro mecanismo de escape muito discutido é o bloqueio da atividade bactericida dos anticorpos pela ação da IgA sérica. A IgA, estimulada pela presença do meningoococo, se liga a superfície dos meningococos, impedindo a fixação das imunoglobulinas dos isótipos $\lg$ e $\lg \mathrm{M}$ e, assim a ação lítica destas imunoglobulinas pela ativação do complemento (Vidarson et al., 2001). Há ainda as cepas de meningococos que produzem uma protease a IgA1 capaz de clivar moléculas de IgA secretórias, anulando com isto a ação antibacteriana da IgA na mucosa do trato respiratório (Vidarson et al., 2001).

Os meningococos expressam duas porinas Por A e Por B, opsoninas humanas e, anticorpos com atividades bactericidas, induzidos durante a doença meningocócica demonstraram o reconhecimento de Por $A$ e Por $B$, e estas porinas podem também fornecer sinais para a indução de Ig espécie-especifica. A porina PorA (classe 1) é o alvo freqüentemente reconhecido por anticorpos bactericidas, e vacinas baseadas em Por A contendo vesículas de membrana externa tem sido desenvolvidas. O lócus de Por B codifica uma das duas classes de proteínas classe 2 ou classe 3 , e é a maior porina constituinte da membrana externa. A Por B é capaz de se inserir dentro da membrana da célula alvo, facilitando então a ligação e invasão das células pelo meningococo. Recentemente, Por B demonstrou ser a causa do influxo celular de $\mathrm{Ca}^{++}$ e indução de apoptose em células alvo (Tzeng \& Stephens, 2000). A proteína de classe 4 (RMP) está associada com as porinas de classe 2/3 na membrana externa e podem ser um alvo para bloquear anticorpos. Ambas as proteínas classe 5 (Opa) e proteínas Opc são importantes na patogênese. Proteínas Opa são variáveis no número de expressão, tamanho, antigenicidade e facilidade de aderência. As moléculas de adesão humanas CD66 são os receptores de proteínas Opa de meningococos. A proteína Opc (formalmente $5 \mathrm{C}$ ) está também envolvida na aderência a células eucarióticas e é um 
alvo de anticorpos bactericidas. Opc possui o receptor celular heparan sulfato dos proteoglicanos, além disso, a Opc se liga a vitronectina que medeia a adesão às células endoteliais através da interação com integrinas, facilitando então a invasão das células endoteliais (Tzeng \& Stephens, 2000).

As proteínas envolvidas na aquisição de ferro (IROMPS), como a lactoferrina e transferrina, também colaboram para o aumento do potencial patogênico do meningococo (Virji et al., 1995; Rosenstein et al., 2001). As IROMPS, em certas condições de crescimento onde há deficiência de ferro, são proteínas de alto peso molecular que são expressas pelos meningococos. "Lactoferrin-binding protein" (Lbp) (100 kDa). A "Iron restriction protein" Frp B (70 kDa) Tbp1 e Tbp2 apresentam variação antigênica enquanto as proteínas ligadas a "Lactoferrin" (Lbp) são estáveis (Danve et al., 1993; Pettersson et al., 1998). Recentemente, foi descrito que o receptor "Lactoferrin" (Lbp) assim como a "Transferrin" (Tbp) são constituídas de duas proteínas, LbpA e LbpB (Petterson et al., 1998).

Em adição às proteínas de membrana externa bacteriana, os meningococos expressam outros componentes, como a lipoproteína H8 (18 kDa) e Laz (17 kDa), uma proteína anaeróbicamente induzida, e Pan 1 (54 kDa), que estão envolvidas no transporte de componentes da cápsula (Poolman, 1995).

Os pili são estruturas essênciais para a interação da bactéria com as células hospedeiras e estão implicadas na colonização da nasofaringe e na habilidade do patógeno em atravessar a barreira hemato-encefálica (Nassif, 2000). Duas classes de pili de meningococos podem ser distinguidas sorologicamente e estruturalmente. Os pili da classe I estão associados à N. gonorrhoeae e os de classe II são pili das cepas de meningococos. Dentro da classe I o pili tipo IV está presente em meningococos e gonococos e demonstram aumentar fortemente a concentração de cálcio intracelular nas células alvos epiteliais. A MCP "membrane cofator protein" ou CD46 é uma glicoproteina regulatória de complemento e tem sido identificada como um pilus receptor para espécies de Neisseria. Vários genes adicionais estão envolvidos na biogênese dos pili. A proteína PilT é requerida para a indução da adesão do meningococo às células epiteliais (Tzeng \& Stephens, 2000). 


\subsection{Epidemiologia}

A doença meningocócica é um problema de saúde publica disseminado por todo o planeta. O risco de casos com ligação temporal e espacial, surtos em grandes epidemias, o potencial fatal da infecção invasiva, as complicações da doença e a possibilidade do desenvolvimento de seqüelas neurológicas permanentes, justificam a busca e a aplicação de medidas de controle para a população.

Os fatores de risco da doença meningocócica incluem a baixa idade, inverno e estações secas, o contato em ambientes fechados com portadores ou ambientes lotados ou mesmo nas comunidades fechadas (como nas universidades, exército ou internatos), doenças respiratórias virais (especialmente influenza), fumantes ativos ou passivos e situação sócio-econômica (Figueroa \& Densen, 1991; Platonov et al., 2003).

Os surtos podem ocorrer a intervalos irregulares e são freqüentemente associados com a introdução de uma nova cepa virulenta na comunidade. Em períodos endêmicos, o percentual de casos em menores de cinco anos é igual ao de maiores, ou seja, de 50\%. Em surtos, ocorre um deslocamento para faixas etárias maiores, ou seja, os maiores de cinco anos passam a ser mais atingido, enquanto o risco (coeficiente de incidência ou taxa de ataque) continua alto nas crianças menores. Na epidemia da década de 70 em São Paulo foi possível verificar, por exemplo, que 50\% dos casos ocorreram apenas na faixa etária de cinco a 24 anos (Hidalgo, 2003).

A sorogrupagem, sorotipagem, subtipagem e o padrão eletroforético das cepas circulantes ajudam na confirmação da ocorrência de um surto ou epidemia, normalmente causados por cepas provenientes de um mesmo clone (Hidalgo, 2003).

A decisão de identificar um "cluster" de casos como um surto é baseado em vários fatores. No surto, as evidências do aumento da transmissão do meningococo na população são manifestadas pelo aumento da incidência, com ausência de contatos entre os casos e/ou comunicantes, ou exposição a lugares comuns. Quando três ou mais casos ocorrem, num período de tempo menor ou igual a três meses, com um coeficiente de incidência maior que 10 casos por 100.000 habitantes, é preciso que haja uma avaliação criteriosa por parte do epidemiologista responsável pela área. Os casos co-primários e secundários deverão ser excluídos desses cálculos, e há que se 
comparar os dados de anos anteriores avaliando-se qual o limiar considerado endêmico para aquela região (Hidalgo, 2003).

A decisão de fazer ou não a quimioprofilaxia está diretamente relacionada com o risco que cada contato tem de adquirir ou não a doença invasiva. Contatos íntimos do caso índice estão sob risco aumentado, mas nem sempre é fácil definir o que é contato íntimo. Uma definição simples e prática utilizada pelos países desenvolvidos, que restringem bastante essa prática, seria: "um indivíduo que freqüentemente dormia ou comia sob o mesmo teto que o caso índice".

É interessante perguntar-se porquê os países desenvolvidos restringem tanto o uso de quimioprofilaxia, criticando inclusive, aqueles que cedem aos comunicantes não íntimos, não domiciliares. Além da possibilidade maior do meningococo criar resistência (isso já ocorreu com o uso da sulfa na década de 60) e dos efeitos colaterais da droga, há estudos demonstrando que o transmissor da cepa virulenta está entre os comunicantes íntimos do paciente; quando se expande muito a quimioprofilaxia, na verdade, está-se erradicando estado de portadores de cepas que não causam doença e conferem imunidade cruzada aos outros meningococos, porque portadores assintomáticos normalmente mantém uma diversidade de sorogrupos e sorotipos, muitas vezes não patogênicos, atingindo até 12\% da população (Hidalgo, 2003).

A cada ano são estimados 1.400 - 2.800 casos de doença meningocócica nos Estados Unidos, uma taxa de 0,5 - 1,1/100.000 na população. N. meningitidis coloniza a superfície mucosa da nasofaringe e é transmitido através do contato direto com as secreções do trato respiratório de pacientes ou portadores assintomáticos. Somente os humanos são os hospedeiros. A despeito da sensibilidade variável dos meningococos a uma ampla variedade de antibióticos, incluindo penicilina (Jackson et al., 1994; Rosenstein et al., 2000), a taxa de mortalidade devido à doença meningocócica é de $10 \%$ a $14 \%$. A doença meningocócica também causa substancial morbidade, 11\% $19 \%$ dos sobreviventes tem seqüelas (instabilidade neurológica, comprometimento de membros e perda da audição) (Edwards, 1981; Kirsch, 1996).

Durante 1991-2002, a alta taxa de pessoas entre onze e dezenove anos de idade $(1,2 / 100.00)$ também foram mais altas do que a população em geral. Embora as taxas da doença sejam altas entre crianças menores de dois anos, $62 \%$ da doença 
meningocócica nos Estados Unidos ocorre entre pessoas menores de onze anos de idade. Nos Estados Unidos, cerca de $98 \%$ dos casos são esporádicos, no entanto, desde 1991, a freqüência de surtos localizados tem aumentado (Jackson et al., 1995; Brooks et al., 2003). A proporção de casos causados pelo sorogrupo $Y$ aumentou de 2\% durante 1989-1991 (Jackson \& Wenger, 1993) para 37\% durante 1997-2002 (Brooks et al., 2003).

Os sorogrupos $\mathrm{B}, \mathrm{C}$ e $\mathrm{Y}$ são a maior causa de doenças meningocócicas nos Estados Unidos, cada um sendo responsável por aproximadamente um terço dos casos. A proporção de casos ocorridos por cada sorogrupo varia conforme a idade. Entre as crianças menores de um ano, mais de $50 \%$ dos casos são ocasionados pelo sorogrupo B, ao qual ainda não há vacina licenciada disponível nos Estados Unidos (Fischer \& Perkins, 1997; Rosenstein et al., 1999). De todos os casos de doença meningocócica entre crianças maiores de onze anos, $75 \%$ foram causadas pelos sorogrupos ( $\mathrm{C}, \mathrm{Y}$ ou $\mathrm{W}-135)$, os quais há vacinas disponíveis incluídas nos Estados Unidos.

A incidência da doença meningocócica no Brasil tem sido monitorada desde que as epidemias do sorogrupo A e C ocorreram entre os anos de 1971 a 1974. Em 1974, os números de casos excederam a 179 casos por 100.000 habitantes. A incidência da doença meningocócica devido a $N$. menigitidis do sorogrupo $C$ na grande São Paulo, tem sido baixa desde o final das epidemias de 1971 e 1972. Entre 1972 e 1974 houve duas epidemias concomitantes, uma causada pelo sorogrupo $C(91 \%$ de todos os casos de meningitis em 1972, e outro, causado pelo sorogrupo A (90\% de todos os casos em 1974). Entre 1981 e 1987, cerca de $83 \%$ dos isolados de meningococos identificados foram do sorogrupo $\mathrm{B}$, onde somente $6 \%$ corresponderam às cepas do sorogrupo C. Em 1988, a incidência de meningites na grande São Paulo, área do Estado de São Paulo, foi de cerca de 4 para cada 100.000 habitantes na grande São Paulo (Sacchi et al., 1998).

Durante este período, os isolados de $N$. meningitidis foram caracterizados pela tipagem sorológica B:4:P1.15. No ano de 2000 , o sorogrupo $C$ predominou sobre o $B$ na grande São Paulo, mostrando, portanto, uma tendência de crescimento percentual desse sorogrupo (Figura 1). A letalidade média nos últimos 10 anos foi de 18,8\% sendo 
muito maior na forma clínica de meningococcemia sem meningite quando comparada com a de meningite sem meningococcemia (56,2\% e 7,7\%, respectivamente) (Figura 2). O risco de adquirir a doença existe para todas as faixas etárias, mas é inversamente proporcional à idade, sendo que dos dois meses a um ano de vida a criança encontrase num período mais susceptível. No estado de São Paulo em 2000, o coeficiente de incidência para menores de cinco anos foi de 28,1 casos por 100.000 habitantes da mesma faixa etária, enquanto que o de maiores de cinco anos foi de 2,0 casos por 100.000 habitantes, portanto 14 vezes maior (Figura 3 ).

Em paises desenvolvidos, onde a doença é mais endêmica, a incidência anual varia entre 1 a 12 para 100.000 habitantes mas pode alcançar 10 a 12 para 100.000 habitantes nas nações em desenvolvimento. Epidemias ocorreram somente ocasionalmente em paises desenvolvidos na metade do século XX, mas foi a maior causa de mortalidade em países não industrializados, especialmente na região do cinturão baixo da África, abrangendo o Senegal, Sudão e Etiópia. Recentemente epidemias do sorogrupo A se espalharam para as regiões vizinhas do Kenya, Burundi e Guinea (Hart \& Cuevas, 1997; Varaine et al., 1997).

São muitas as cepas patogênicas de $N$. meningitidis, embora a doença seja indistinguível nas suas características clinicas. Algumas cepas podem estar associadas com a forma mais severa da doença. Um grande aumento da doença causada por clones de meningococos tem sido observado em vários paises. A cepa ET-5 de meningococos é responsável pela doença hiperendêmica em Oregon, cepas hipervirulentas do sorogrupo C ET-37 são particularmente responsáveis pelo aumento da doença no Reino Unido (Pollard et al., 2000). Houve um notável aumento da doença causada pelo sorogrupo $Y$ na Inglaterra e Illinois na década de 90 e a Nova Zelândia recentemente foi acometida por uma nova cepa epidêmica causada pela B: 4: P.1.4 (Pollard et al., 2000).

Em muitos paises industrializados as cepas predominantes causadoras de doenças são as do sorogrupo $B$, responsáveis por dois terços dos casos. As cepas do sorogrupo $C$ compõem o restante dos casos e, portanto, são requeridas vacinas para ambos os sorogrupos B e C para prevenir os efeitos da doença. A taxa de meningococos do sorogrupo $Y$ notada nos Estados Unidos recentemente sugere que 
outros sorogrupos possam estar incluídos em um programa de vacinação. O sorogrupo A é o sorogrupo predominante na África, mas são raros os casos de doenças em paises desenvolvidos (Pollard \& Levin, 2000).

A totalidade da taxa de mortalidade da doença meningocócica varia de $2 \%$ a 10\% (Peltola, 1983), mas a taxa de mortalidade por septicemia (sem meningites) é consideravelmente alta, cerca de $20-30 \%$ ou mais (Peltola, 1983). Na Noruega a taxa da mortalidade pela doença meningocócica tem sido cerca de $11 \%$ podendo chegar a $25 \%$ em algumas regiões. Na África a taxa de mortalidade da doença meningocócica chega a $22 \%$ e na Suécia na década de 80 foi de 4,3-9,2\% (Salih et al., 1990; Berg et al., 1992).

Em um recente levantamento na Suécia foi encontrado que $10 \%$ dos sobreviventes da doença meningocócica sofreram de seqüelas permanentes. A seqüela pode ser divida em deterioração das funções psíquico-neurológicas e danos teciduais devido a deterioração da circulação periférica (Berg et al., 1992). A seqüela mais comum na Suécia foi de perda da audição com freqüência de $5 \%$ e $6 \%$. Outras seqüelas das funções psíquico-neurológicas consistem em deficiência motora, hidrocefalia, ataques, lesões do nervo cranial, comprometimento intelectual, problemas comportamentais e déficit cognitivo (Peltola, 1983). Danos teciduais devido à degeneração da circulação periférica, necroses e disfunções renais ocorrem em baixa porcentagem (Berg et al., 1992). 


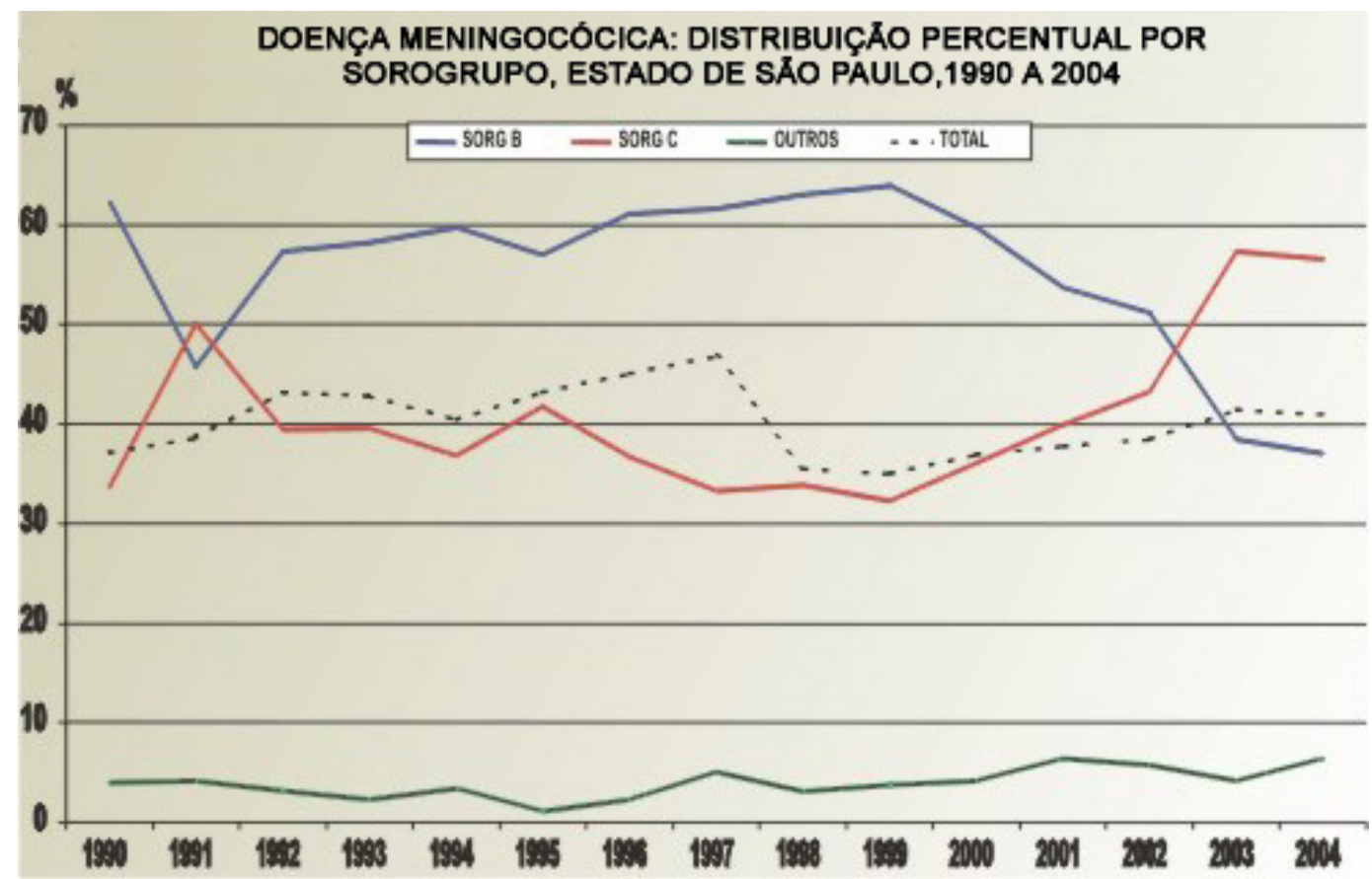

Figura 1: Doença Meningocócica: distribuição percentual por sorogrupo, Estado de São Paulo, 1990-2004.

Atualmente, o percentual de sorogrupagem da DM no Estado de São Paulo é de $41 \%$. A partir de 2003, observou-se variação positiva em relação ao percentual do sorogrupo $C$ em comparação com o sorogrupo $B$, isto é, aumento da proporção do sorogrupo $\mathrm{C}$. Porém, não houve aumento da incidência dos casos de DM no decorrer deste período.

(Fonte: Sinanw/DDTR /CVE, dados em 8/4/2005) 


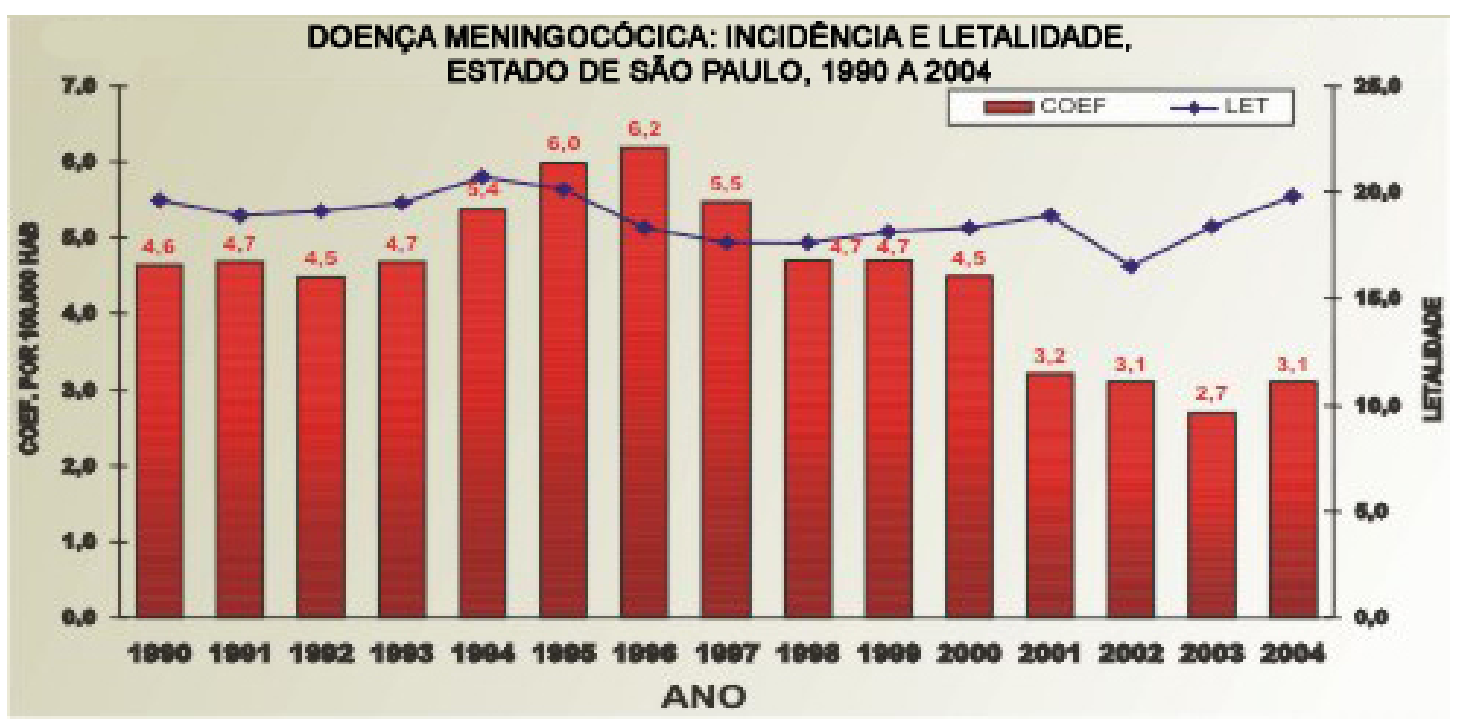

Figura 2: Doença Meningocócica: incidência e letalidade no Estado de São Paulo,19902004

O maior risco de adoecimento situou-se em crianças menores de 4 anos de idade, com as seguintes variações nas taxas: 56,2 - 29/100.000 hab. (< 1 ano) e 23,26 $11,42 / 100.000$ hab. (1 - 4 anos), nos últimos dez anos. Acrescente-se que $50 \%$ dos casos de DM no Estado ocorrem nos primeiros quatro anos de vida. A partir daí, as taxas de ataque diminuem acentuadamente em relação às demais faixas etárias.

(Fonte: Sinanw/D.D.T.R. / CVE, dados em 8/4/2005)

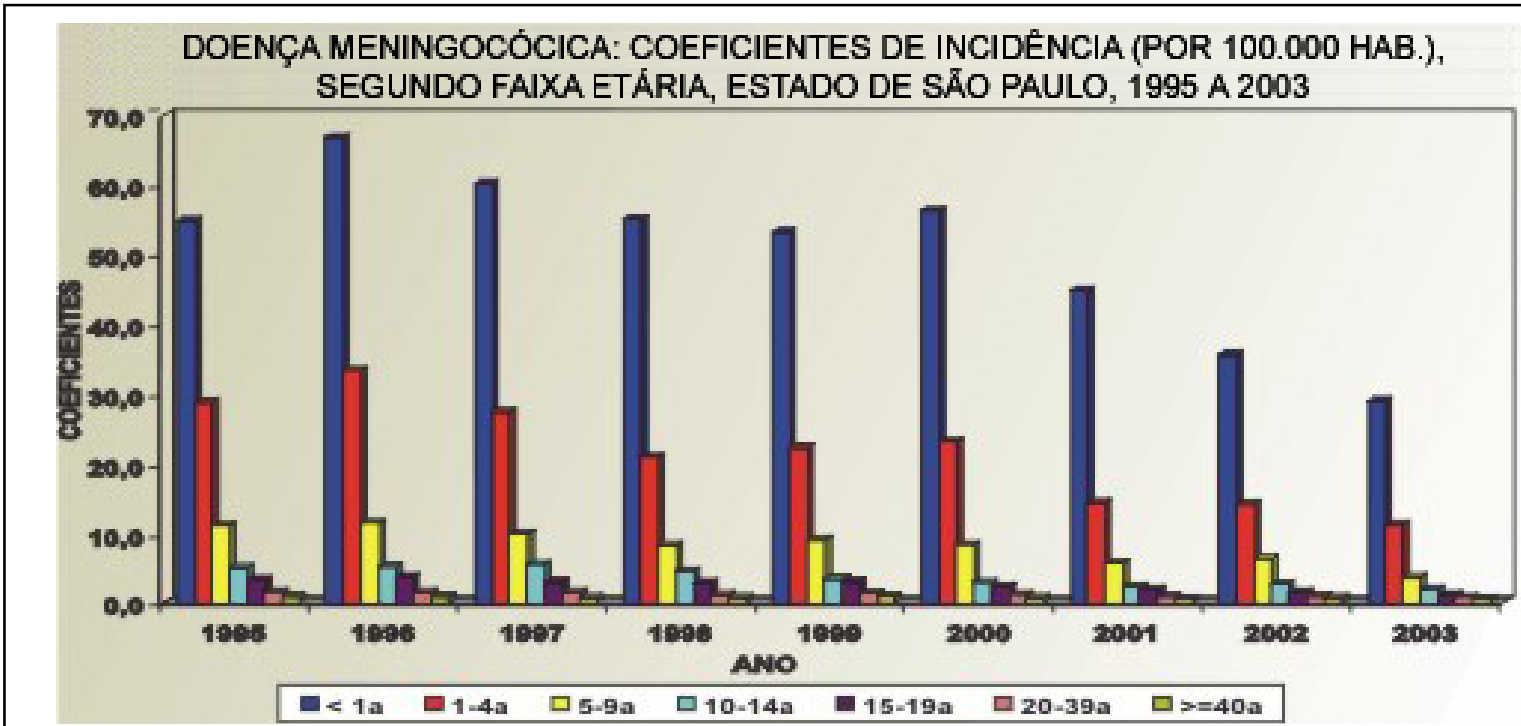

Figura 3: Doença Meningocócica: coeficientes de incidência (por 100.000 hab.), segundo faixa etária, Estado de são Paulo, 1995 a 2003

A incidência da DM, segundo sorogrupo e faixa etária, demonstrou predomínio do sorogrupo $B$ nas faixas de $<1$ ano, 1 - 4 anos e 5 - 9 anos, porém sem diferenças significativas nas demais faixas etárias. A letalidade pelo sorogrupo $B$ foi significativamente mais expressiva quando comparada ao sorogrupo C.

(Fonte: D.D.T. RESPIRATÓRIA / CVE, dados em 15/4/2004) 


\subsubsection{Prevalência de $N$. meningitidis e espécies de Neisserias comensais relatadas em humanos:}

As cepas de $N$. meningitids estão presentes na flora normal da orofaringe de adultos e crianças. A prevalência dos portadores de N. meningitidis varia geograficamente. Pouco menos de $1 \%$ de crianças são colonizadas por $N$. meningitidis durante os quatro primeiros anos de vida, a taxa de portadores aumenta após esta idade (Bovre, 1984; Knapp, 1988).

N. lactamica coloniza mais freqüentemente crianças do que adultos. N. lactamica coloniza cerca de $4 \%$ bebês de três meses de idade e atinge um pico de $21 \%$ em crianças de dezoito a vinte e quatro meses. A colonização por $N$. lactamica tende a declinar a $2 \%$ dos quatorze aos dezessete anos de idade. É estimado que $59 \%$ das crianças são colonizadas por $N$. lactamica durante os primeiros quatro anos de vida. Este padrão de colonização pode refletir no fato de que as crianças pequenas podem ingerir grandes volumes de leite. Entre as espécies de Neisseria, as cepas de $N$. lactamica são as únicas que tem a habilidade de usar a lactose, esta característica pode aumentar a população de $N$. lactamica nas crianças pequenas. $N$. lactamica normalmente não está implicada em causar patogenia como $N$. gonorrhoeae e $N$. meningitidis, embora eventualmente possa ser um patógeno oportunista (Bovre, 1984; Knapp, 1988).

As espécies de Neisseria que colonizam a nasofaringe de adultos correspondem a: N. sicca $(45 \%)$, N. perflava (40\%), N. subflava e N. flava $(11 \%)$ e "N. catarrhalis" $(3 \%)$ (Bovre, 1984). Em um estudo de prevalência realizado na população de espécies de Neisseria comensal nos Estados Unidos, foi verificado que muitos adultos foram colonizados por duas ou três espécies, $5 \%$ das pessoas foram colonizadas por quatro ou cinco tipos de espécies de Neisseria, sendo que a prevalência dos tipos de cepas de Neisserias comensais variaram geograficamente. Cepas de N. subflava biovar perflava colistina-resistentes foram isoladas repetidamente em Chicago, embora não com muita freqüência na cidade de DeKalb na Geórgia e Seattle em Washington (Vedros, 1984; Bovre, 1984; Knapp, 1988). 


\subsection{Resposta Imune}

O conhecimento da resposta imune é importante para o desenvolvimento de vacinas, no entanto, o mecanismo de defesa contra a doença invasiva causada por $N$. meningitidis em humanos ainda não está totalmente esclarecido. A imunidade é adquirida como resultado da exposição a antígenos de meningococos expressos pela colonização de Neisserias não patogênicas e outros organismos de reatividade cruzada (Frank, 1987). Através da medida dos níveis de anticorpos com atividade bactericida é possível determinar o aumento da imunidade durante a infância. Os mecanismos de imunidade humoral incluem indução de anticorpos, lise pelo complemento, fagocitose mediada por anticorpos e citotoxidade celular dependente de anticorpo.

Os mecanismos da resposta imune inata podem ser muito importantes na defesa contra a infecção meningocócica durante a infância, estes mecanismos incluem ativação do complemento, opsonização não especifica e fagocitose além da integridade da mucosa nasofaringea. Os defeitos na maturação da imunidade inata em combinação com baixos níveis de imunidade antígeno-específica são responsáveis pelo aumento da incidência da doença (Pollard \& Levin, 2000). Além disso, indivíduos com hipogamaglobulinemia e deficiência de componentes do complemento - especialmente de C3, inativador de C3b, C5, C6, C7 e C8 e de componentes finais da cascata do complemento - são mais susceptíveis à doença (Frank, 1987).

Os anticorpos induzidos contra os meningococos são de diferentes classes de imunoglobulinas e, portanto tem diferenças funcionais. A imunoglobulina do isótipo IgG pode iniciar uma série de funções efetoras, como interação com componentes do sistema complemento como o $\mathrm{C} 1 \mathrm{q}$, apresenta também papel importante no desenvolvimento da resposta imune celular como a citotoxidade dependente de anticorpos. Em contraste, a IgA não se liga ao $\mathrm{C} 1 \mathrm{q}$, não ativando a via clássica do complemento, além de bloquear a atividade bactericida e ativação de anticorpos lgG e $\operatorname{lgM}$, enquanto IgM é extremamente potente na ativação do sistema complemento (Vidarson et al., 2001). Anticorpos IgM possuem maior atividade bactericida do que as anticorpos da classe IgG (Craven et al., 1982). Os anticorpos da classe IgG em resposta a infecção são predominantemente das subclasses lgG1 e lgG3, a lgG2 
provavelmente também aparece em crianças mais velhas, mas anticorpos da subclasse lgG4 não são detectáveis (Pollard \& Frasch, 2001).

Está claro que via alternativa do complemento, que não depende de anticorpo, é crucial na proteção contra a doença meningocócica, mas ainda não está claro qual a importância da ativação da via alternativa do complemento na resistência à infecção causada pelo sorogrupo $\mathrm{B}$, uma vez que a cápsula do ácido siálico e a sialilação do LPS do sorogrupo $B$ inibem a ativação da via alternativa do complemento in vitro (Pollard \& Frasch, 2001).

A deficiência da ligação manose-lecitina (MBL) está associada com o aumento da susceptibilidade à infecção, incluíndo a infecção meningocócica, MBL liga-se ao carboidrato presente na superfície de bactérias, leveduras, protozoários e vírus e é estruturalmente similar ao C1q e é capaz de ativar o complemento quando associado a proteases serina (MASP-1 e MASP-2), a morte é mediada através da lise pelo complemento ou pelo aumento da fagocitose. Então, o complemento e $\mathrm{MBL}$ desempenham um importante papel na resposta imune inata através da opsonização dos meningococos e da ativação da via alternativa do complemento (Pollard \& Frasch, 2001).

Muitas das interações entre as células da resposta imune são mediadas por substâncias solúveis (geralmente peptídeos de baixo peso molecular) que foram originalmente chamados de linfocinas, mas são agora mais conhecidos pelo termo citocinas por eles serem produzidos por diferentes tipos de células (Jacobs \& Tabor, 1990; van Deuren et al., 1992). Vários estudos indicam que a citocina fator de necrose tumoral alfa (TNF- $\alpha$ ) é um importante mediador do choque séptico (Beutler et al., 1986; Beutler \& Cerami, 1987). Os TNF- $\alpha$ são liberados por monócitos/macrófagos em resposta a endotoxina LPS, e altas concentrações de TNF-- $\alpha$ estão fortemente associadas com a doença meningocócica invasiva e fatal (Waage et al., 1987). A liberação de interleucina-1 (IL-1) das células endoteliais e macrófagos é induzida pelo TNF- $\alpha$. Subseqüentemente, a produção de IL-1 estimula a biossíntese de outras citocinas. Ambos, IL-1 e TNF- $\alpha$ induzem a liberação de interleucina-6 (IL-6) pelas células endoteliais (Waage et al., 1989). É possível que somente a IL-6 ou a interação com TNF- $\alpha$. IL-1 ou LPS estejam envolvidos na patogênese do choque séptico (Waage 
et al., 1987). A interleucina 8 (IL-8) é uma citocina que ativa somente PMNL mas também outras células, por exemplo células endoteliais (Quagliarello \& Sheld, 1992). Pacientes com choque séptico devido à doença meningocócica tem concentrações mais altas de IL-8 no soro do que pacientes sem a doença severa. A cinética de IL-8 no soro é similar a IL-6, ambas aparecem depois da TNF- $\alpha$ no soro (Halstensen et al., 1991; Waage \& Aasen, 1992).

Os PMNL respondem à invasão microbiana com uma série de eventos que podem ser divididos dentro de três estágios principais: quimiotaxia, fagocitose e morte celular. Quando os PMNL reconhecem um fator quimiotático, ocorre a aderência às células endoteliais e a produção de TNF- $\alpha$ e e IL-1 aumentam a expressão de moléculas de selectina sobre a membrana das células endoteliais nas quais os PMNL se aderem. Simultaneamente, as citocinas (principalmente a IL-8) ativam a expressão de moléculas de adesão ICAM-1 no endotélio que, mediada pela integrina, favorece a ligação e a diapedese dos PMNL e, portanto, a sua emigração do sangue para os tecidos (Quagliarello \& Sheld, 1992). Os fatores quimiotáticos podem ser divididos dentro de dois grupos, endógenos e exógenos. Dentre os mais potentes grupos endógenos estão os C5a, outros fatores quimotáticos endógenos incluem IL-1. Os fatores quimiotáticos exógenos são peptídeos de baixo peso molecular que podem ser derivados de bactérias (Marasco et al., 1984).

A fagocitose da bactéria envolve dois passos: ligação e ingestão. Os PMNL possuem numerosos receptores diferentes para uma variedade de ligantes, incluíndo certos peptídeos bacterianos, leucotrienos B4, a porção Fc da imunoglobulina IgG e vários fatores do complemento. A ligação de anticorpos e/ou complemento na superfície da bactéria é chamada de opsonização. A bactéria opsonizada é facilmente fagocitada pela ligação aos receptores $F c$ e $C 3$ na superfície dos PMNL e subseqüente ingestão. A fagocitose também pode ocorrer sem a utilização de receptores específicos. Este tipo de reconhecimento não opsônico entre o fagócito e sua presa é chamado lectinofagocitose (Ofek \& Sharon, 1988). A bactéria pode, por exemplo, apresentar lectinas da superfície que se liga a carboidratos da superfície das células fagocíticas. Isto mostra também que a diminuição da hidrofobicidade da bactéria se correlaciona com a tendência à interação com os PMNL (Dahlgren et al., 1981; Magnusson, 1989). 
Os mecanismos pelos quais os receptores Fc e C3 medeiam a ingestão podem diferir, o receptor FcRII promove a ingestão, enquanto que FcRIII promove a ligação. O receptor CR3 é menos eficiente em promover a ingestão a menos que os PMNL tenham sido ativados por sinais adicionais. As interações entre os ligantes da bactéria e as estruturas da superfície dos PMNL tem a propriedade de produzir sinais transmembrana que iniciam a formação de pseudópodes nos PMNL, estes englobam a bactéria, formando o fagossomo (Fredlund, 1993).

Os PMNL possuem dois diferentes sistemas antimicrobianos, um oxigênio independente e outro oxigênio dependente. $\mathrm{Na}$ morte independente de oxigênio, os PMNL durante a fagocitose são estimulados a liberar enzimas com propriedades bactericidas, proteolíticas e de danos teciduais. Diferentes grupos de enzimas têm sido descritos, por exemplo, a proteína de aumento da permeabilidade bactericida (BPI), defensinas e proteínas catalíticas, a descarga do conteúdo granular é alcançada pela fusão entre os grânulos e a membrana fagossomal (Henson et al., 1988). Na morte dependente de oxigênio, o metabolismo oxidativo dos PMNL é ativado durante a ligação, resultando em um "burst" respiratório o qual é iniciado com a ativação de uma enzima $\mathrm{NAD}(\mathrm{P}) \mathrm{H}$ oxidase. $\mathrm{A} N \mathrm{NA}(\mathrm{P}) \mathrm{H}$ é gerada através da hexose monofosfato. $E$ tem sido proposto que a ativação da enzima é dependente da fusão de grânulos intracelulares e da membrana plasmática, onde ela catalisa a redução do oxigênio ao anion superóxido $\left(\mathrm{O}_{2}{ }^{-}\right)$. Este metabólito se dismuta espontaneamente, gerando peróxido de hidrogênio $\left(\mathrm{H}_{2} \mathrm{O}_{2}\right)$. Estes dois metabólitos do oxigênio participam da geração de mais metabólitos reativos e tóxicos, como o radical hidroxila $\left(\mathrm{OH}^{-}\right)$, ácido hipoclorídrico ( $\mathrm{HOCl}$ ) e oxigênio single $\left({ }^{1} \mathrm{O}_{2}\right)$ para o efeito microbicida (Babior, 1984).

\subsection{Imunidade de Mucosa}

A nasofaringe é o sítio de colonização pelos meningococos e presumivelmente possa ser o sítio primário da invasão inicial para o desenvolvimento da infecção sistêmica (Pollard \& Frasch, 2001).

Portadores de $N$. lactamica - uma espécie de Neisseria não patogênica que coloniza especialmente crianças pequenas - estão associados com altos títulos de anticorpos contra N. meningitidis. Embora somente cerca de $3,8 \%$ de crianças menores 
de três meses de idade portam $N$. lactamica, a taxa de portadores aumenta cerca de $21 \%$ em crianças de vinte e oito meses e voltam a cair a menos de $2 \%$ por volta dos quatorze e dezessete anos de idade. Em contraste, crianças menores de quatro anos portam $0,71 \%$ de N. meningitidis contra $5,4 \%$ de jovens (Pollard \& Frasch, 2001).

Várias interações entre bactérias e as estruturas das células da superfície mucosa estão envolvidas na aderência e invasão dos meningococos e o polimorfismo destas moléculas. Os meningococos aderem à mucosa nasofaríngea via interações entre as células epiteliais humanas e os pili bacterianos e proteínas de membrana externa (Pollard \& Frasch, 2001).

Há provavelmente inúmeros fatores que contribuem para a integridade da barreira mucosa e previne a colonização e invasão. A superfície da mucosa nasal possui cargas e hidrofobicidade que estão relacionadas com a adesão bacteriana, ou seja, mudanças desta carga podem resultar na adesão bacteriana, como ocorre com maior facilidade em fumantes que estão mais predispostos à doença na forma invasiva (Pollard \& Frasch, 2001).

Portadores de meningococos provavelmente também são influenciados pela competição da flora bacteriana, como com N. lactamica. Anticorpos anti-meningococos nas secreções nasofaringeas provavelmente desempenham o maior papel na prevenção da colonização e invasão desta bactéria (Pollard \& Frasch, 2001).

O maior isótipo de anticorpo encontrado nas secreções mucosas é da classe lgA ( $\operatorname{sg} \mathrm{A}$ ), estima-se que um adulto normal de $70 \mathrm{Kg}$ secrete aproximadamente $3 \mathrm{~g}$ de $\lg \mathrm{A}$ por dia contribuindo para 60 a $70 \%$ deste isótipo de anticorpos.

A IgA secretória (slgA) tem propriedades físico-químicas que diferem-na da $\lg A$ devido a sua natureza polimérica (poli-lgA) e está associada ao componente secretório (SC), uma glicoproteína de $80 \mathrm{kDa}$ de origem epitelial (Brandtzaeg, 1992). A lgM secretória (slgM) também está associada com SC e segue a mesma via intracelular pelo epitélio glandular que a slgA. A cadeia $\mathrm{J}$ da IgM pentamérica juntamente com SC são cruciais para a translocação externa da imunoglobulina polimérica (Brandtzaeg \& Prydz, 1984).

Desde a identificação e o conhecimento sobre a função da slgA, sabe-se que a grande superfície das áreas mucosas, cerca de $300-400 \mathrm{~m}^{2}$ são protegidos pelo 
sistema imune adaptativo local e a indução e expressão da resposta imune de mucosa se correlaciona com a resistência contra infecções bacterianas, particularmente do trato respiratório superior (Brandtzaeg, 1992).

A maior função da slgA e slgM é a cooperação com uma variedade de fatores de defesa inata para neutralizar toxinas e vírus e para prevenir a aderência e a penetração de microrganismos patogênicos (Brandtzaeg \& Prydz, 1984). A absorção de carcinogênios pode ser inibida pela slgA. A produção local de slgA é crucial para manter a homeostase nos tecidos de mucosas, no entanto, a $\lg \mathrm{A}$ e sua subclasse slgA carecem de potentes funções efetoras como ativação da via clássica do complemento, porém podem exercer efeitos anti-fagocíticos pelo bloqueio de mecanismos biológicos de amplificação inespecíficos induzidos por $\lg G$, $\lg M$ e $\lg \mathrm{E}$.

O tecido imune de mucosas é formado pelo tecido linfóide associado ao intestino (GALT), estruturas linfóides associadas com o broncoepitélio e trato respiratório baixo (BALT), tecido ocular, glândulas salivares, tonsilas e nasofaringe (NALT), laringe, trato urogenital, glândulas mamárias e produtos da lactação (LALT). Os folículos linfóides organizados do GALT (placas de Peyer) e BALT são considerados os principais sítios indutores da resposta imune (Staats et al., 1994). O conjunto de todos estes sítios designam o tecido linfóide organizado (MALT), que consiste de áreas enriquecidas de células $T$ e $B$ com alta porcentagem de células $B$ produtoras de slgA e APCs necessárias à indução de respostas imunes especificas. O revestimento do MALT é composto por células epiteliais especializadas que compõem o epitélio folículoassociado - (FAE). Tais estruturas são encontradas na cavidade nasal, nos brônquios e nos intestinos (Ogra, 1996). Dispersas nessa barreira encontra-se um tipo de células chamadas células $M$ que são especializadas na captação e transporte de macromoléculas, antígenos particulados e microrganismos por meio de transocitose. As células $M$ são ativamente pinocitárias e transportam macromoléculas da luz intestinal para os tecidos subepiteliais, contém invaginações profundas na membrana plasmática basolateral que formam bolsas contendo linfócitos $T$ e $B$, células dendríticas e macrófagos. Os antígenos e microrganismos são transocitados para estas bolsas e para o tecido linfóide organizado das mucosas, sob o epitélio. A aderência e a captação de um microrganismo pelas células $M$ envolvem uma série de eventos que 
incluem: o reconhecimento inicial, a íntima relação (que requer a expressão de genes específicos), a ativação e a sinalização intracelular. A captação do antígeno pelas células $M$ não resulta em degradação do antígeno, servindo apenas como transporte, feito pelos endossomos, vesículas e grandes corpos multivesiculares (Neutra \& Kraehendhl, 1996).

As partículas maiores que $1 \mu \mathrm{m}$ não são capazes de se ligar às células $M$, devido a sua barreira molecular a grandes partículas. A capacidade de captação das partículas ligadas à superfície apical da membrana plasmática torna as células $M$ importantes para o desenvolvimento de vacinas de mucosas. As células $M$ não são exclusivas das placas de Peyer, mas também são encontradas em associação aos acúmulos de células linfóides em outros locais mucosos. Além de constituírem o MALT, um grande número de linfócitos e plasmócitos também podem ser encontrados na mucosa do estômago, nos intestinos delgado e grosso, nas vias aéreas superiores e inferiores e na mucosa de vários outros órgãos, onde se distribuem no tecido conjuntivo da lamina própria e no interior da camada epitelial. Os linfócitos da lâmina própria são predominatemente, células $T$ ativadas, mas também podem ser encontrados numerosos linfócitos $B$ e plasmócitos secretores de $\operatorname{lgA}$, a qual é transportada através das células epiteliais e liberada no lúmen (Roitt et al., 1999).

A ativação das células $T$ resulta na liberação de diferentes citocinas e quimiocinas e no reconhecimento de epítopos antigênicos envolvendo moléculas MHC de classe I ou II. Tanto a ativação das células T como a liberação de citocinas estão envolvidos no eventual processo de ativação das células $B$, no switching dos isótipos e na expressão de integrinas específicas sobre as células $B$ sensibilizadas. Ambas células Th1 e Th2 beneficiam o desenvolvimento da resposta slgA (Kelsall \& Strober, 1997). As citocinas liberadas por Th2 (IL-4, IL-5, IL-6, IL-9, IL-10 e IL-13) podem auxiliar na produção de anticorpos, a resposta de slgA também pode ser induzida através de citocinas IL-2 e TNF- $\alpha$ pelas Th1 (Nataro \& Levine, 1999). As células T helper, principalmente as Th2 ativadas localmente promovem inflamação persistente da mucosa com extravasamento de células inflamatórias, incluindo eosinófilos, esta fase de defesa local, faz parte dos processos alérgicos, talvez iniciados pela ação da IL-4 que agem sobre os mastócitos na liberação de IgE (Nataro \& Levine, 1999). 
As células dendríticas estão presentes em diferentes componentes do sistema imune comum de mucosas, incluindo o tecido linfóide organizado e o epitélio de mucosa. Estas células podem ser fortemente associadas com a potencialidade da resposta imune, no entanto, recentes estudos sugerem que as células dendríticas podem também aumentar a indução de tolerância de mucosa in vivo. As células dendríticas são potentes apresentadoras de antígenos (APC) e são criticas no início da resposta imune primária, na rejeição de enxertos, doenças auto-imunes e geração de células $T$ dependentes. A função da APC é atribuída em parte a sua habilidade de expressar moléculas co-estimulatórias (CD80 e CD86) e outros ligantes necessários para a indução de tolerância (Ogra et al., 2001).

\subsubsection{Tecido linfóide nasal associado (NALT)}

As placas de Peyer's (PP) são conhecidas como indutoras dos sítios para as respostas imunes humoral e celular no trato gastrointestinal, em contraste com estruturas funcionalmente equivalentes encontradas no trato respiratório. Isto nos tem sugerido que o tecido linfóide nasal associado (NALT) pode servir como um sítio indutor de mucosa no trato respiratório. No entanto, sinais típicos de indução de mucosa como o desenvolvimento do centro germinativo das reações após a estimulação com antígeno e o switching dos isótipos das células B para a produção de IgA não têm sido diretamente demonstrado (Zuercher et al., 2002b). Acredita-se que o tecido linfóide nasal associado (NALT) do trato respiratório dos murinos possa ser equivalente ao Waldeyer's em humanos (Kuper et al., 1992). Ele consiste de um par de tecidos linfóides localizados no assoalho da cavidade nasal delineado por células ciliadas do trato respiratório, como tem sido postulado em diferentes estudos como um possível equivalente e funcionalmente as PP no intestino.

Vários achados suportam esta hipótese: primeiro - a composição celular do NALT é similar as $\mathrm{PP}$, ambos os tecidos contem uma população majoritária de células $\mathrm{B}$ bem como as células T(CD45RB ${ }^{\text {high})}$ (Wu et al., 1996; Heritage et al., 1997; Asanuma et al., 1997); segundo - têm sido demonstrado que em camundongos, tanto no NALT como nas PP há uma camada sobreposta do epitélio contendo células $\mathrm{M}$ e epitélio folículoassociado que podem servir como sítio de entrada para diferentes patógenos (Morin et 
al., 1994; Velin, et al. 1997); terceiro - sob a estimulação do antígeno, o maior isótipo de imunoglobulinas produzidas pelas células B do NALT são do isótipo IgA (Carr et al., 1996; Wu et al. 1997).

As glândulas salivares e glândulas lacrimais foram sugeridas como um possível sitio efetor para a produção de $\operatorname{lgA}$, as quais refletem pela presença de anticorpos IgA na saliva e fluido lacrimal. A despeito destas similaridades, diferenças entre PP e NALT, como uma divergência marcante na expressão e função de receptores têm sido reportada (Gallichan, et al., 1993; Porgador et al., 1997). Outros sítios indutores de mucosas expressivos, como os centros de formação germinativos bem como o switching de isótipos e expansão das células de superfície $B \lg A+$ sob a estimulação do antígeno não tem sido demonstrado em NALT, assim como não está concluído se a citotoxidade celular (CTL) pode ser gerada no NALT (Zuercher et al., 2002a).

No estudo realizado por Zuercher et al. (2002a), o NALT foi analisado funcionalmente e estruturalmente usando um modelo de infecção intranasal em camundongos $\mathrm{C} 3 \mathrm{H}$ com retrovirus. Foi realizada análise por FACS e análise histológica que revelou o desenvolvimento de centros germinativos em NALT em paralelo com a geração e expansão de células $\mathrm{B} \quad \operatorname{lgA}^{+}$e $\operatorname{lgG} \mathrm{a}^{+}$após infecção nasal com retrovirus. Foi produzida IgA retrovirus-específica tanto no trato respiratório superior como no trato gastrointestinal, onde a produção de IgG2a retrovirus-específica foi restrita ao NALT, linfonodos mesentéricos e submandibular. No entanto, CLT vírus-específica foi detectada no NALT. Todos estes dados forneceram uma evidência direta de que NALT pode ser um sítio de mucosa indutor de resposta imune humoral e celular no trato respiratório superior.

\subsubsection{Administração De Vacinas Pela Via De Mucosa Nasal}

A administração de vacinas pela via nasal tem sido freqüentemente proposta como uma alternativa mais fácil do que as injeções pela via parenteral. Isto ocorre devido à alta permeabilidade do epitélio nasal, permitindo uma taxa de absorção rápida e quase idêntica às injeções intravenosas (Ugwoke et al., 2001). A secreção nasal é uma complexa mistura de vários materiais e consiste de aproximadamente $95 \%$ de água, $2 \%$ 
de mucina, $1 \%$ de sais, $1 \%$ de outras proteínas como a albumina, imunoglobulinas, lisozimas, lactoferrina e menos de $1 \%$ de lipídeos (Kaliner et al., 1984).

A produção de imunoglobulina $A$ pelo tecido adenóide e pela mucosa nasal desempenha um papel muito importante na resposta imune contra bactérias e virus (Bernstein et al., 1997). O muco contém glicoproteínas que consistem de um núcleo de proteína composto por oligossacarídeos de cadeias dissulfido e ligado por pontes de hidrogênio (Thaete et al., 1981). São produzidos aproximadamente 1,5 litros de muco diariamente (Marom et al., 1984; Chien et al., 1989). Esta manta de muco, com aproximadamente $5 \mu \mathrm{m}$ é composta de duas camadas sendo a camada inferior composta por um gel de alta viscosidade, conseqüentemente esta viscosidade pode afetar os batimentos ciliares e transportar o muco e favorecendo ao clearence mucociliar (MCC) (Kamath \& Park, 1994).

O muco nasal realiza uma serie de funções fisiológicas (Chien, 1995): ele recobre a mucosa e a protege fisicamente e enzimaticamente, ele adere e transporta as partículas da nasofaringe, e previne o pulmão contra o ataque de alérgenos, bactérias, virus, toxinas etc. Quando tais materiais são aderidos ou dissolvidos no muco da cavidade nasal eles são transportados através da nasofaringe para uma eventual descarga no trato gastrointestinal (GIT). O clearence deste muco e as substâncias dissolvidas no GIT são chamados de MCC (Ugwoke et al., 2001).

A administração de drogas no sistema circulatório através de injeções intravenosas ou por infusão é superior a outras vias de administração com respeito à ação terapêutica. Devido a este acesso direto à circulação, o metabolismo e a degradação destas é feito no fígado e GIT. Além disso, uma absorção constante e prolongada da droga pode ser alcançada por um determinado período, no entanto pode levar a certos riscos de saúde quando administrado em pacientes crônicos. Uma constante taxa de liberação da droga também pode ser alcançada pela via transdérmica, no entanto há algumas limitações incluindo o fato de que ela pode ser usada para liberar somente drogas lipofílicas excluindo desta forma um grande número de outras drogas candidatas. E também a fase lag de absorção é mais lenta levando várias horas ou mais devido à baixa permeabilidade do estrato corneum altamente queratinizado (Ugwoke et al., 2001). 
Uma rápida e alta concentração de drogas pode ser alcançada através da administração pela via intranasal, há cerca de duas décadas estudos reconhecem que a cavidade nasal é uma potencial via para a administração de drogas. As vantagens à cerca da cavidade nasal incluem: a extensa área de superfície do epitélio respiratório que é recoberto por microvilosidades que aumentam a absorção das drogas, e também por ser um epitélio altamente vascularizado o qual permite uma rápida ação terapêutica. A membrana basal endotelial tem poros que transportam as substâncias para dentro do sistema circulatório (ou ainda para dentro do sistema nervoso central), desta forma eliminando os primeiros passos quando da administração pela via oral, além da baixa atividade enzimática comparada com o fígado e GIT proporcionando menos efeitos colaterais e aumentando a segurança da medicação e diminuindo os riscos de superdosagem (Ugwoke et al., 2001).

Existem vários tipos de dispositivos para a administração de drogas pela via intranasal: para as formulações líquidas estão incluídos os cateteres de instilação, conta-gotas, compartimentos de dose única, frascos de instilar, sprays, aerossóis, ar comprimido e inaladores, existem também dispositivos para géis nasais (Kublik \& Vidgren, 1998). A escolha do dispositivo de administração de drogas nasais deve levar em conta os custos e a facilidade para ser usado pelo paciente, precisão e reprodutibilidade da dosagem e deposição bem como o clearence da cavidade nasal, uma vez que todos estes fatores influenciam na absorção nasal (Ugwoke et al., 2001).

A despeito das vantagens da administração de drogas pela via nasal, esta via também tem algumas limitações como: a cavidade nasal tem um limite de volume restrito de quantidade de formulação que pode ser administrado, conseqüentemente, somente baixas doses ou drogas com alta solubilidade em água podem ser administradas via intranasal e que não venham a influenciar as funções fisiológicas normais da cavidade nasal especialmente com respeito à olfação e inspiração. $A$ absorção nasal de muitas drogas, especialmente aquelas com moléculas hidrofílicas como peptídeos e proteínas é limitado. Ainda embora o cut-off de massa molecular de absorção de drogas da cavidade nasal seja aproximadamente de 1000 Da mais alta do que a do GIT (500 Da), ainda assim excluem o uso de muitas drogas candidatas (Ugwoke et al., 2001). 
A cavidade nasal ainda tem uma barreira enzimática que pode causar proteólise de algumas enzimas podendo reduzir a absorção de alguns peptídeos (Hussain et al., 1985, 1990b, 1992; Stratford \& Lee, 1986). Mas pode-se incorporar um inibidor enzimático específico na formulação como uma alternativa, isto pode ser alcançado sem provocar efeitos adversos na mucosa nasal. (Hussain et al., 1990a).

O MCC é um outro fator limitante para a absorção de drogas via nasal, este mecanismo de defesa natural do trato respiratório baixo contra infecções e outras substâncias pode diminuir a absorção (Soane et al., 1999). A irregular deposição de substâncias instiladas pode também ocorrer com certa freqüência, sendo um outro fator limitante, o tipo de formulação, o dispositivo de administração, o tamanho das partículas e o estado da cavidade nasal do paciente também devem ser considerados. A mucosa nasal é muito sensível a irritações, portanto as propriedades toxicológicas são as maiores limitações na escolha de drogas para a administração nasal (Ugwoke et al., 2001).

Dada as vantagens e limitações da disponibilidade das drogas pela via nasal, estas candidatas precisam ter inúmeros atributos como: solubilidade aquosa apropriada, causar mínima irritação nasal, clinicamente disponível de forma racional, baixas doses (geralmente menos que $25 \mathrm{mg}$ ), sem metabólitos tóxicos, sem aromas ou odores ofensivos, e terem características estáveis (Ugwoke et al., 2001).

Vários modelos experimentais podem ser usados para o estudo da administração de drogas via intranasal, o uso de coelhos oferece inúmeras vantagens, eles são disponíveis para estudos famacocinéticos e farmacodinâmicos. Adicionalmente repetidos experimentos pode ser realizados com o mesmo animal, isto pode reduzir os custos dos experimentos e a variabilidade dos dados. Os coelhos têm uma grande abertura da cavidade nasal (orifício) quando comparado ao de camundongos, sendo fácil a administração das drogas. Experimentos farmacocinéticos podem ser realizados sem necessitar de anestesia, especialmente alguns anestésicos que podem inibir o MCC (Raphael et al., 1996a, 1996b), os quais podem afetar a absorção nasal das drogas. Outras vantagens incluem o preço relativamente baixo, fácil disponibilidade, manutenção e manuseio do animal. O volume total do sangue (aproximadamente 150 $\mathrm{mL}$ ) pode permitir repetidas amostras de sangue. $O$ ramo do septo nasal dos coelhos 
são anatomicamente similar ao dos cachorros. Na mucosa respiratória predominam o epitélio pseudo-estratificado e epitélio ciliado colunar com células de globet. A pele presente na cavidade nasal dos coelhos tem uma área de superfície e volume ainda maior do que em humanos e a sua dócil natureza, que facilita a administração intranasal é a maior vantagem (Gizurarson, 1993).

\subsection{Sistema Imune Em Coelhos}

Evidências recentes sugerem que o coelho pode usar um mecanismo de conversão gênica para diversificar este único gene $V_{H}$ (Knight \& Becker, 1990). Estas observações são incomuns aos outros mamíferos, pois nestes, a diversificação no arranjo dos genes Ig ocorre por mutações somáticas, e pouco, ou nada ocorre por conversão gênica (Gearhart et al., 1981; Clarke et al., 1985; French et al., 1989; Kocks \& Rajewsky, 1989; Maizels, 1989; Wysocki \& Gefter, 1989).

Uma das maiores dificuldades em se trabalhar com coelhos é o numero limitado de anticorpos monoclonais e de probes de DNA específicos para as moléculas de relevância imunológica, uma vez que não há marcadores disponíveis para células pré-B de coelhos. Knight \& Crane (1994), desenvolveram probes de DNA e anticorpos monoclonais específicos para coelhos e identificaram as células pré-B que apresentavam a superfície Ig-negativa mas tinham cadeia $\mu$ citoplasmática, usando estes mesmos critérios. Hayward et al. (1978) e Mc Elroy et al. (1981), mostraram que células pré-B de coelhos aparecem primeiramente no fígado aos 17-21 dias de desenvolvimento fetal, e na medula óssea em cerca de 25 dias.

No fígado, o nível de células pré-B permanecem por pouco tempo (até 10 dias) após o nascimento. Na medula óssea, Hayward et al. (1978), estimaram que o nível de células pré-B é alto, aproximadamente $9 \%$, um dia após o nascimento e rapidamente diminui para $2 \%$ dois dias após o nascimento e para $1 \%$ no $21^{\circ}$ dia. A presença de $1 \%$ a $3 \%$ de células pré-B na medula óssea em coelhos adultos pode ser usada para argüir que a linfopoiese das células B continua a ocorrer nos coelhos adultos igualmente ao que ocorre com os camundongos (Osmond, 1990). No entanto, sugere-se que nos coelhos adultos estas células pré-B são quiescentes, que a linfopoiese ocorre cedo na ontogenia e que as células B são auto-renováveis e que, como nas aves, pouca ou 
nenhuma linfopoiese de linfócitos B ocorre em adultos (Pink et al., 1986; Cooper \& Burrows, 1989).

$\mathrm{Na}$ embriogênese das aves, as células migram para a bursa de Fabricius, e os genes das cadeias $V_{H}$ e $V_{H}$ sofrem diversificação por conversão somática de genes (Reynaud et al., 1985, 1987). Dentro da bursa são desenvolvidos folículos altamente desenvolvidos que desempenham um importante papel nos processos de diversificação e, portanto, no desenvolvimento do repertório primário de anticoprpos. Nos coelhos, devido à estrutura folicular do GALT, notavelmente o apêndice, parecer com a bursa e porque os genes VDJ dos coelhos também se diversificam por conversão somática dos genes, foram investigados se o GALT dos coelhos é funcionalmente equivalente a bursa das aves. Então o GALT pode ser o sitio em que se desenvolve o repertório primário de anticorpos nos coelhos (Knight \& Crane, 1994).

O GALT também possui células especializadas chamadas células $M$, que tem a função de eliminar muito dos patógenos qua agem na superfície epitelial, elas se ligam e transportam os patógenos da membrana plasmática apical para a invaginação basolateral, que contem células linfóides de defesa imune (Lelouard et al., 2001). No intestino delgado, as células pluripotentes stem cells residem dentro das criptas onde se desenvolvem e proliferam os precursores das linhagens, que se diferenciam progressivamente em enterócitos e células $M$ de mucosa, as quais migram em direção da cripta ao longo das vilosidades e saem poucos dias depois (Lelouard et al., 2001).

A distribuição espacial das células $\mathrm{M}$ e dos enterócitos está geralmente estabelecida na base da cúpula do apêndice e das placas de Peyer dos coelhos. Segundo o estudo de Lelouard et al. (2001), a distribuição das células M e dos enterócitos no apêndice revelam um padrão mosaico muito regular da base para a parte superior da cúpula e poucas células de globet aparecem na parte de baixo da cúpula do apêndice e placa de Peyer (Cheng \& Leblond, 1974). Lelouard et al. (2001), propôs que nas placas de Peyer em coelhos, muitas células $M$ podem estar inascessíveis ao tamanho de certos antígenos bacterianos ou microesferas, devido a sua pequena área de superfície, a qual é quase completamente coberta por microvilos de enterócitos adjacentes. Após uma estimulação antigênica, a área de supefície das células $M$ pode aumentar o recrutamento de linfócitos. O recrutamento dos linfócitos têm sido 
demonstrado pela injeção de Shigella flexneri não-invasiva (Sansonetti et al., 1996) ou Streptococcus pneumoniae (Borghesi et al., 1996) nas placas de Peyer em coelhos. Desta forma ocorre uma expansão das células $M$ formadas pela conversão $e$ diferenciação dos enterócitos após o desafio bacteriano (Savidge et al., 1991; Meynell et al., 1999).

\subsection{Vacinas para Meningites}

As vacinas iniciais baseadas em whole cells de meningococos mortas pelo calor causaram a incerteza da sua eficácia devido aos níveis inaceitáveis de reações adversas provavelmente devido ao alto conteúdo de endotoxina (Morley \& Pollard, 2001). A primeira triagem da vacina feita em recrutas do exército em 1900 teve eficácia de $87 \%$ e foi preparada de isolados clínicos recentes durante a epidemia do sorogrupo A e provavelmente dependia da presença de antígenos polissacárides (Morley \& Pollard, 2001).

Em 1930, Ferry e colaboradores iniciaram uma pesquisa para uma vacina baseada em exotoxina de meningococos numa tentativa de repetir o sucesso alcançado com a vacina toxóide diftérica (Morley \& Pollard, 2001). Eles investigaram o potencial da vacina composta de sobrenadantes de caldo de cultura de meningococos e o possível efeito clinico mediado pela toxina sobre a pele e encontraram resultados similares ao induzido pela toxina de streptococcus. De fato, esta toxina contém um cocktail de polissacáride capsular, proteínas de membrana externa e lipopolissacárides. Estudos demonstraram a redução da doença meningocócica em jovens do sexo masculino vacinados com esta toxina, mas não provaram conclusivamente a imunogenicidade $\mathrm{e}$ eficácia desta exotoxina (Morley \& Pollard, 2001).

O primeiro sucesso da vacinação contra os meningococos foi alcançado em 1960 por Gotschlich e colaboradores que demonstraram a importância de anticorpos anti-polissacárides contra os sorogrupos A e C no soro de humanos (Morley \& Pollard, 2001). Eles desenvolveram um novo método para a produção de polissacáride de meningocococos altamente purificados de alto peso molecular e em 1969 demonstraram que polissacárides preparados desta maneira eram imunogênicos em adultos. 
As vacinas de polissacárides usadas na rotina clínica são as dos sorogrupos $\mathrm{A} e$ $C$ ou $A, C, Y$ e W135. Embora amplamente usado nos surtos e epidemias de meningococos $\mathrm{A}$ e $\mathrm{C}$ bem como para profilaxia em grupos de alto risco (viajantes para áreas de alto risco, recrutas militares, estudantes universitários e pacientes com imunodeficiências) dois fatores cruciais têm limitado o uso destas vacinas, primeiramente, polissacárides purificados são fracamente imunogênicos em crianças pequenas que são mais susceptíveis à doença, e, segundo, a duração da imunidade induzida é limitada e dependente da idade (Morley \& Pollard, 2001).

Os polissacárides dos sorogrupos A, C, Y e W135 induzem anticorpos sorogrupo específico. Estes anticorpos dirigidos contra os polissacárides são bactericidas e podem dar proteção contra as doenças causadas pelos sorogrupos correspondentes. A primeira vacina contendo polissacárides livre do antígeno foram desenvolvidas na década de 50 . Hoje inúmeras combinações de vacinas estão sendo manufaturadas: a vacina bivalente A C combinada com glicoproteínas e também a tetravalente ACYW135. Estas vacinas são bem toleradas e oferecem proteção a crianças entre três e cinco anos contra a doença causada pelos meningococos dos sorogrupos $A$ e $C$, e A, C, Y e W135, respectivamente (Bröker, 2003). Em muitos paises da Europa e América do Norte, em vista da relativa baixa incidência da doença meningocócica, a vacinação não é incluída nos programas de rotina para crianças, mas usadas apenas quando indicado. Ela é indicada, por exemplo, para indivíduos com deficiência de componentes do complemento ou de properdina e para indivíduos que sofreram asplenia bem como para viajantes que vão para regiões endêmicas que tenham contato direto com a população local. As vacinas de polissacárides livres de antígeno também têm certas desvantagens. Elas, por exemplo, não são adequadamente imunogênicas em crianças menores de dois anos de idade, a proteção é de curta duração (aproximadamente três a cinco anos), e a resposta imune não é estimulada, uma vez que a indução de anticorpos dirigidos contra os principais polissacárides é células T-independentes. Além disso, repetidas imunizações podem ter o efeito de reduzir a resposta imune, ou seja, levar a uma hiporresponsividade (Bröker, 2003).

Para a eficácia de novas preparações vacinais contra meningites, são necessários vários requisitos: a vacina deve oferecer proteção contra todos os 
sorogrupos de meningococos patogênicos; ser efetiva para crianças menores de dois anos de idade; induzir proteção imune de longa duração; ser capaz de induzir respostas com altos títulos de anticorpos; ser capaz é claro, de ter uma boa segurança e boa tolerância (Bröker, 2003).

As vacinas de meningococos glicoconjugadas consistem de oligossacarídeos parcialmente hidrolisados derivados do polissacáride capsular e químicamente conjugado a proteínas transportadoras (Morley \& Pollard, 2001). As vacinas glicoconjugadas A, C, Y, W135 demonstram induzir respostas de células Tdependentes contra os antígenos polissacarides devido a sua ligação à proteína que é então capaz de recrutar células T-helper de resposta imune. O espetacular sucesso desta técnica foi à produção da vacina Haemophilus influenzae tipo b (Hib), a qual erradicou virtualmente a doença em países que implantaram os programas de vacinação em crianças que posteriormente liderou a aplicação desta técnica, através da ligação de Hib aos polissacárides capsulares de meningococos (Morley \& Pollard, 2001).

Estudos da imunogenicidade usando as vacinas glicoconjugadas dos sorogrupos A e $C$ demonstram induzir níveis de anticorpos em crianças pequenas que podem induzir proteção (Pollard \& Frasch, 2001). Crianças vacinadas aos dois e quatro meses de idade com vacina do sorogrupo $C$ glicoconjugada produziram altos níveis de anticorpos com atividade bactericida, fornecendo evidências de indução de memória imunológica (Morley \& Pollard, 2001).

Inúmeras companhias farmacêuticas têm desenvolvido as vacinas do sorogrupo $C$ glicoconjugadas, e o desenvolvimento das vacinas contra outros sorogrupos ( $A, Y$ e W135) estão em estágio avançado. As vacinas atualmente licenciadas contêm toxóide tetâtico ou CRM197 como proteínas transportadoras, ambas tem sido usadas na vacina de $H$. influenzae $B$ e são consideradas seguras e imunogênicas (Morley \& Pollard, 2001). Por estas razões espera-se que as vacinas tetravalentes A, C, Y e W135 conjugadas possam obter sucesso assim como a $H$. influenzae $B$ glicoconjugada.

Os meningococos exibem acentuada plasticidade genética em face à seleção imunológica e a rápida troca de antígenos "switching" (incluindo antígenos capsulares), e a probabilidade de tais trocas ocorrerem podem ser minimizadas pela vacinação 
contra os múltiplos sorogrupos da vacina tetravalente $A, C, Y$ e W135, contudo, a manufaturação da vacina tetravalente ainda tem muitas limitações, como: a produção, purificação e processamento downstream de cada polissacáride precisam ser trabalhados individualmente, bem como os processos de conjugação dos polissacárides com proteínas transportadoras, e finalmente, a questão de que a combinação de quatro antígenos vacinais possa interferir com a estabilidade e imunogenicidade em animais, e clinicamente com respeito a imunogenicidade e tolerabilidade em humanos. Há também que ser excluída a possibilidade de interferência com as vacinas de rotina usualmente utilizadas como a DTP, Hib, HBV, e possíveis vacinas futuras, por exemplo, a vacina pneumocócica (Bröker, 2003).

Atualmente vem sendo estudada a combinação da vacina tetravalente com outras vacinas, por exemplo, com Hib ou conjugada com pneumococos, com o intuito de diminuir o numero de injeções e produzir uma vacina de meningitis multi-valente.

Até hoje, nós não temos uma vacina que proteja contra a doença causada pelo sorogrupo $B$, a despeito do fato que o sorogrupo $B$ é o responsável por muitos casos de doenças em paises industrializados. Isso ocorre porque o polissacáride do sorogrupo $B$ é fracamente imunogênico, o antígeno é um polímero de ácido $\alpha$-D-N-acetyl neuramínico (também chamado de ácido siálico), o qual é ligado a $2 \rightarrow 8$ ( $2 \rightarrow 8 \alpha$-DNeuNac). Estruturas muito similares também são encontradas na superfície de células humanas, em particular a molécula de adesão neuronal (N-CAM) das células neuronais (Finne et al., 1987). Isto leva ao reconhecimento de células próprias e efeito de tolerância imunológica para o polissacáride do sorogrupo $B$, como resultado, a resposta imune é muito fraca e induz anticorpos principalmente da classe $\lg \mathrm{M}$, mas nenhuma imunoglobulina da classe $\operatorname{lgG}$. A efetiva produção de anticorpos contra o polissacáride do sorogrupo B pode levar a uma forte reação de auto-imunidade. Outra razão para a fraca imunogenicidade do polissacáride do sorogrupo B pode ser devido a sua instabilidade ao baixo $\mathrm{pH}$ e ao fato de que a cápsula antigênica pode rapidamente ser degradada pela enzima neuraminidase. No entanto, o polissacáride do sorogrupo B pode ser quimicamente ligado a uma proteína transportadora para superar a tolerância natural do antígeno polissacáride (Devi et al., 1991). A primeira vista, esta tentativa pode ser promissora, mas deve-se levar em conta os riscos potenciais. Embora os 
antígenos de polissacárides modificados pelo processo de conjugação induzem resposta com altas concentrações de anticorpos contra o antígeno bacteriano, estes anticorpos podem também reagir com outras estruturas próprias do corpo (Finne et al., 1987) como resultado, uma injeção com tais antígenos, pode possivelmente induzir a auto-imunidade (Bröker, 2003).

Em vista das dificuldades das vacinas de polissacárides contra a doença causada pelo meningococo do sorogrupo $B$, varias estratégias e alternativas de vacinação foram realizadas. A aquisição de anticorpos bactericidas tem demonstrado uma correlação inversa com a incidência da doença para o sorogrupo $B$ bem como para os sorogrupos A e C (Morley \& Pollard, 2001). Ainda não está esclarecido se os títulos de anticorpos bactericidas contra o sorogrupo B estão correlacionados com a proteção contra a doença, no entanto, tem sido sugerido que a proteção contra a infecção pelo sorogrupo B pode ser devido a anticorpos com atividade de opsonisação e das respostas imunes inatas, as quais não participam dos ensaios de atividade bactericida (Lehmann et al., 1991; Ison et al., 1999).

Outros ensaios que demonstram atividade de opsonisação têm sido sugeridos como os mais apropriados marcadores de proteção do que a atividade bactericida (Lehmann et al., 1991; Ison et al., 1999).

Diferentemente da doença causada pelos sorogrupos A e C, o sorogrupo B provavelmente apresenta anticorpos bactericidas dirigidos principalmente contra antígenos não-capsulares (Frasch, 1995; Jones et al., 1979). Estes antígenos nãocapsulares que consistem de proteínas de membrana externa e LPS, são, portanto considerados candidatos promissores às vacinas para o sorogrupo B. O principal impedimento do uso de proteínas de membrana externa como candidatas à vacina é a sua heterogeneidade antigênica. Vacinas baseadas em proteínas de membrana externa de uma única cepa do sorogrupo B demonstram ser imunogênicas (Bjune et al., 1991; Boslego et al., 1995).

O sucesso destas vacinas têm sido limitado pela relativa restrição da cepa, geralmente pouco imunogênica em crianças pequenas e evidência de curta duração da resposta imune (Bjune et al., 1991). A despeito destas restrições, estas vacinas monovalentes podem ser administradas nas doenças hiperendêmicas do sorogrupo $B$ 
envolvendo um único tipo antigênico (Bjune et al., 1991; Sierra et al., 1991; Rodriguez, 1999).

Varias estratégias têm sido empregadas para ampliar a cobertura das vacinas de proteínas de membrana externa, usualmente envolvendo o uso de antígenos de múltiplos tipos antigênicos. A última meta, no entanto, é a descoberta de um antígeno (ou mais de um grupo de antígenos), que esteja presente em todas as cepas de meningococos do sorogrupo $B$ e seja capaz de induzir respostas protetoras tanto em adultos como em crianças. A recente publicação do seqüenciamento completo do genoma dos meningococos dos sorogrupos A e B tem contribuído grandemente para este trabalho (Morley \& Pollard, 2001). Um outro problema significante que impede o desenvolvimento da vacina contra o sorogrupo $B$ é a falta de uma aceitável proteção, o que não ocorreu com o uso mundial das vacinas de polissacárides para os sorogrupos A e $C$ nos programas de vacinação no controle de epidemias que favoreceram um aumento quadruplicado de títulos bactericidas e de níveis de imunoglobulinas IgG antipolissacárides.

\subsection{Vacinas Atuais em Desenvolvimento para o Sorogrupo B}

\subsubsection{Vacinas Propioniladas Conjugadas}

Uma vacina que dirija com sucesso uma resposta imune contra o polissacarídeo capsular do meningococo do sorogrupo B pode ser a solução para uma vacina, visto que, por definição, este antígeno é compartilhado por todos os membros deste sorogupo. Infelizmente, a cápsula é fracamente imunogênica, um fenômeno que é descrito pela tolerância imunológica do hospedeiro aos glicopeptídeos do ácido siálico.

Em uma tentativa para superar tal tolerância, Jennings et al. (1987), desenvolveram um polissacarídeo quimicamente modificado que continha grupos $\mathrm{N}$ propionil no lugar dos grupos $\mathrm{N}$-acetil encontrados na posição $\mathrm{C} 5$ dos resíduos de ácido siálico. Este polissacarídeo semi-sintético foi então conjugado ao toxóide tetânico para produzir uma nova vacina glicoconjugada que foi altamente imunogênica em camundongos (Jennings et al., 1986; Ashton et al., 1989). Uma vacina similar, que difere somente no uso de uma proteína Por B recombinante ao invés do toxóide tetânico como transportador, também tem demonstrado ser imunogênica em primatas 
(Fusco et al., 1997), com indução de anticorpos lgG que são bactericidas para os meningococos do sorogrupo B. Uma proporção de anticorpos produzidos tem a habilidade de se ligar ao ácido polisiálico e pode portanto ter atividade de autoanticorpo (Fusco et al., 1997; Granoff et al., 1998). Embora não tenha havido a evidência de auto-anticorpos deletérios nos animais de laboratório estudados, a presença destes anticorpos numa preparação vacinal pode resultar em doenças autoimunes ou que auto-anticorpos possam ser produzidos e atravessarem a placenta, causando anormalidades neurológicas no desenvolvimento fetal. Em estudos de teratogenicidade não foram documentados efeitos deletérios na triagem em humanos ou em animais (Danve et al., 1996; Bruge et al., 1996).

\subsubsection{Vacinas de Proteínas de Membrana Externa (OMP) e Vesículas de Membrana Externa (OMV)}

As primeiras tentativas para a produção de vacinas baseadas em proteínas de membrana externa datam da década de 70 e eram baseadas na depleção do LPS da proteína de membrana externa pelo tratamento com detergente. As OMPs eram então precipitadas para produzir agregados suspendidos em cloreto de sódio. A despeito dos resultados promissores em estudos animais, estas vacinas falharam na indução de anticorpos bactericidas em adultos e crianças (Frasch, 1995; Claasen et al.,1996). A baixa performance destas vacinas foi atribuída à perda da estrutura terciária que acompanhava a precipitação. O próximo passo era, portanto, produzir uma vacina com proteínas dispostas na sua conformação nativa na forma de vesículas de membrana externa (OMV) (Zoollinger et al., 1979; Wang \& Frasch, 1984). As vesículas eram similares aos blebs que são liberados naturalmente pelos meningococos durante 0 crescimento (Devoe \& Gilchrist, 1973).

A depleção do LPS foi realizada seletivamente usando detergente (Zollinger et al., 1979; Sierra et al., 1991). Estas vesículas de membrana externa foram significativamente mais imunogênicas do que os agregados de OMP e a imunogenicidade demonstrou ainda mais aumentada pela adsorção do adjuvante hidróxido de alumínio (Wang \& Frasch, 1984). Um recente estudo sugere que o fosfato de alumínio pode aumentar a imunogenicidade (De Kleijn et al., 2000). 
As duas vacinas mais extensivamente estudadas foram desenvolvidas em 1980 em resposta ao surto de doença ocorrido em Cuba (Sierra et al., 1991) e Noruega (Bjune et al., 1991). A vacina de OMV produzida pelo Instituto Finlay em Cuba (comercialmente chamada de VA-MENGOC-BC®) foi produzida da cepa B: 4: P1.19,15 com polissacarídeo do sorogrupo $\mathrm{C}$ e uma preparação de OMP de alto peso molecular e adsorvida com hidróxido de alumínio (Sierra et al., 1991). A vacina foi designada em resposta a uma única cepa (B: 4: $\mathrm{P} 1.19,15)$ epidêmica da doença meningocócica a qual houve uma grande eficácia de cerca de 95\% num regime de duas doses administradas em programa de vacinação a jovens e crianças de três meses a dezenove anos de idade no ano de 1988, a qual contribuiu para o rápido declínio da epidemia em Cuba (Rodriguez et al., 1999).

Subseqüentes estudos de eficácia da vacina foram realizados no Brasil durante um surto epidêmico da doença meningocócica causada por vários sorogrupos $\mathrm{B}$ e $\mathrm{C}$ incluindo a cepa B: 4: P1.19,15, e embora tenha ocorrido a proteção em cerca de $70 \%$ em crianças mais velhas, não houve proteção semelhante em crianças mais jovens (De Moraes et al., 1992; Milagres et al., 1994; Noronha et al., 1995).

A vacina produzida pelo Norwegian National Institute for Public Health (NIPH) foi inicialmente designada para o uso durante o período epidêmico da doença causada por um outro organismo do clone ET-5 (B: 15: P.1.7,16), ela também era uma vacina monovalente produzida por vesículas de membrana externa purificadas adsorvida com hidróxido de alumínio (Bjune et al., 1991), e foi administrada em um regime de duas doses em crianças de vinte e nove meses no período de 1988 a 1991 onde houve uma eficácia de cerca de $57 \%$, no entanto, o efeito da vacina foi de curta duração ocorrendo um aumento da incidência da doença nos vacinados no final do período em estudo (Bjune et al., 1991; Sierra et al., 1991).

As vacinas compostas de vesículas de membrana externa, as quais apresentam as proteínas na sua conformação natural, produzem anticorpos bactericidas em jovens e adultos. Os anticorpos gerados em resposta também demonstram aumento da oposonofagocitose dos meningococos. A precisa formulação das vacinas compostas de OMP e LPS na presença ou ausência de adjuvantes tem um significante impacto na imunogenicidade (Lehmann et al., 1991; Gomez et al., 1998; Steeghs et al., 1999). 
As proteínas Por A e Por B são imunogênicas em humanos e podem induzir anticorpos com atividade bactericida. A desvantagem destes antígenos, no entanto, é o fato de que eles têm poucas estruturas conservadas, e então podem ser eficazes somente a um sorotipo ou subtipo especifico. Ainda assim, vacinas meningocócicas sorotipo-específicas podem ser de grande valor, em particular quanto aos surtos e epidemias causados usualmente por um único sorotipo (Bröker, 2003).

Estudos de pós-vacinação realizados pelo NIPH sugerem que anticorpos contra Por A (proteína de classe 1) e a OpcA (uma OMP anteriormente conhecida como Opc) eram ambas importantes na mediação de anticorpos com atividade bactericida, sendo a Por A mais imunogênica, no entanto, estudos feitos na Noruega demonstraram evidências de atividade bactericida advindas de OMPs (Wedege et al., 1998).

A proeminência de anticorpos bactericidas contra a proteína Por A na pósvacinação (e pós-doença) e o significante nível de variabilidade desta proteína, a qual parece sofrer contínua variação entre e durante os surtos, reforça (no que diz respeito à proteção oferecida das vacinas baseadas em OMV) que ela é restrita ao subtipo (isto é, dependente de Por A). Numa tentativa de superar este problema, foi desenvolvida uma vacina de OMV pelo National Institute of Public Health and Environment na Noruega que continha proteínas Por A proveniente de seis isolados patogênicos diferentes prevalentes e específicos para uma determinada área geográfica (Van Der Ley, 1992; Claasen et al., 1996). As vesículas da vacina foram extraídas de duas cepas variantes denominadas $\mathrm{H} 44 / 76$ a qual tinha sido geneticamente modificada para expressar três proteínas Por A (Van Der Ley, 1992; Claasen et al., 1996). Esta seleção de proteínas Por A foi direcionada para cobrir cerca de $80 \%$ das cepas patogênicas circulantes na Europa ocidental, embora se supõe não levar em conta a subseqüente mudança nas cepas predominantes circulantes e o aumento do numero de variantes de cada subtipo neste intervalo de tempo. Esta vacina foi capaz de induzir atividade bactericida contra as cepas das seis proteínas Por A em crianças pequenas e nas pré-escolares quando administradas num programa de três doses da vacina (Cartwright et al., 1999). 


\subsubsection{Vacinas Baseadas em um Antígeno Universal}

Outra linha de investigação provém à busca de um antígeno universal para todas as cepas de meningococos que eliminaria o problema potencial do "switching capsular" que pode aparecer na vacinação contra os polissacárides capsulares (Alonso, 2003). Estão em estudo as proteínas de classe 5 (OpcA), a NspA (22 kDa) o lipopolissacarídeo (LPS), as proteínas reguladas pelo ferro (IRPS), das quais as TbpA e TbpB tem sido as mais estudadas, a proteína NadA (190 kDa) descoberta através do sequenciamento do genoma do meningococo B da cepa virulenta MC58 também estão sendo estudadas (Pintor et al., 1998; Vazquez, 2002). A NspA (22kDa) tem uma homologia em cerca de $97 \%$ com as cepas de meningococos o que implica que ela pode ser uma boa candidata a vacina (Cadieux et al., 1999). A imunização com a proteina NspA recombinante demonstrou induzir reatividade cruzada e resposta de anticorpos bactericidas em camundongos contra as cepas dos sorogrupos $\mathrm{A}$ e $\mathrm{C}$.

A proteína NadA descrita recentemente por Comanducci et al. (2002), é uma proteína oligomérica com uma massa molecular de 190 kDa em SDS-PAGE, e tem sido descrita como proteína de superfície de membrana externa presente em várias cepas de meningococos dos sorogrupos B e C e são fortes indutoras de anticorpos bactericidas. Recentemente, Fukasawa et al. (2003), estudaram um anticorpo monoclonal contra a proteina NadA da cepa 3006 de N. meningitidis sorogrupo B (B: 2b: P1.2: P5.2,8) que demonstraram forte atividade bactericida contra a cepa epidêmica (B: 4,7: P1.19,15: P5.5,7) do meningococo sorogrupo B do Brasil e contra a cepa IMC 2135 (C: 2a: P1.5,2) do meningococo sorogrupo C. Também testaram a imunogenicidade da NadA em camundongos imunizados com uma preparação de OMV da cepa do meningococo sorogrupo B (B: 4,7: P1.19,15: P5.5,7) que continha a proteína NadA , onde foi demonstrado atividade bactericida contra as cepas dos sorogrupos $\mathrm{B}$ e $\mathrm{C}$ que possuiam NadA. Em análise de dot-blot o anticorpo monoclonal testado contra a NadA reconheceu cerca de $60 \%$ das amostras analisadas dos isolados dos sorogrupos B e C do Brasil.

Rappuoli et al. (2002), descreveram a NadA como um novo antígeno de superfície presente em cerca de 53 cepas hipervirulentas de $N$. meningitidis das linhagens (ET) ET37, ET5 e grupo A4. O gene está ausente na linhagem hipervirulenta 
III, em N. gonorrhoeae e espécies de Neisseria comensais como $N$. lactamica e $N$. cinerea. A NadA tem uma estrutura molecular muito similar a nova classe de adesinas (YadA e UspA2), oligomérica de alto peso molecular, e se liga às células epiteliais in vitro suportando a hipotese que NadA é importante na interação com as células do hospedeiro. NadA também induziu anticorpos com atividade bactericida e protegeu modelos de camundongos neonatos sugerindo que esta proteína pode reperesentar um novo antígeno candidato para uma vacina capaz de controlar a doença meningocócica causada pelas três linhagens virulentas.

Uma outra vacina candidata é a de LPS, anticorpos contra LPS são encontrados no soro de pacientes e alguns dos anticorpos são bactericidas (Tramont et al., 1974; Griffiss et al., 1984). Um estudo feito em macacos rhesus com uma vacina OMV do sorogrupo B demonstrou a presença de anticorpos anti-LPS bactericidas no soro (Zollinger et al., 1997). Plested et al., estudaram um anticorpo em camundongos que reconhecia um epítopo conservado do LPS em mais de $70 \%$ de uma coleção de sorogrupos B e A de meningococos, considerado como potencial para a vacina de LPS (Plested et al., 1999).

Um outro estudo com vacina conjugada de LPS com epítopo conservado foi imunogênico e produziu atividade bactericida contra algumas cepas heterólogas (Arumugham et al., 1998). As vacinas de LPS têm o potencial de induzir anticorpos de reatividade cruzada contra múltiplos meningococos do sorogrupo $B$.

O recente seqüenciamento do genoma da cepa virulenta MC58 de $N$. meningitidis do sorogrupo B abriu o caminho para o que se pode denominar de vacinologia reversa, mediante a qual se identificam os segmentos de DNA de Neisseria que geram o aparecimento de anticorpos bactericidas. Tettelin et al. (2000) expressaram em E. coli 350 fragmentos de DNA que, uma vez purificados, foram inoculados em camundongos. Destes se identificaram 85 antígenos de superfície, dos quais 25 induziram o aparecimento de anticorpos bactericidas com títulos similares aos obtidos com as vacinas de vesículas de membrana externa efetivas. Além disso, a maioria dos novos anticorpos teria uma seqüência conservada com cepas representantes da população meningocócica, desta forma através desta tecnologia poder-se-ia conseguir imunidade frente a várias cepas de N. meningitidis. Por outro 
lado, se abrem novas perspectivas através da recente identificação de 73 genes do genoma de $N$. meningitidis essenciais, para que num futuro próximo sejam elaboradas vacinas baseadas nos produtos desses genes, o que permitiria uma resposta imune eficiente contra o meningococo B (Sun et al., 2000).

Recentemente, De Gaspari (2000b), descreveu uma proteína de massa molecular atribuída ao peptídeo de $50 \mathrm{kDa}$ presente na superfície bacteriana de $\mathrm{N}$. meningitidis e que induz anticorpos com reatividade cruzada para diferentes sorogrupos, sorotipos e subtipos e com alta capacidade de proteção. Através da produção de um anticorpo monoclonal originado de uma linhagem de células de hibridomas que produziu um clone denominado $8 \mathrm{C} 7 \mathrm{Br} 1$ produtor de anticorpos da classe IgM que reconheceu os peptídeos de 50,65 e $60 \mathrm{kDa}$ com reatividade para $98 \%$ das cepas de $N$. meningitidis $B$. Além de ter reatividade cruzada com $N$. gonorrhoeae, N. lactamica, H. influenzae B, E. coli, S. typhimurium, S. flexneri, B. pertussis e $B$. subtilis. O Mab $8 \mathrm{C} 7 \mathrm{Br} 1$ através da análise por citometria de fluxo pode reconhecer a proteína de $50 \mathrm{kDa}$ na superfície de $N$. meningitidis da cepa homóloga (B:4: P1.9). Estes resultados associados com testes de atividade bactericida do $8 \mathrm{C} 7 \mathrm{Br} 1$ e um estudo de proteção passiva em camundongos, demonstraram a potencial importância da proteína de $50 \mathrm{kDa}$ de reatividade cruzada, como candidata a composição de uma vacina para meningites tipo $\mathrm{B}$.

\subsubsection{Vacinas Baseadas na Imunidade Cruzada com outras Neisserias}

Outras vias na busca de uma vacina frente ao meningococo sorogrupo B poderiam advir do estudo da imunidade cruzada entre $N$. meningitidis e $N$. lactamica (Sanchez et al., 2002a). A N. lactamica carece de cápsula polissacarídica e compartilha antígenos comuns com $N$. meningitidis. A colonização da nasofaringe por $N$. lactamica em crianças constitui um estímulo para a imunidade natural contra N. meningitidis. Uma substancial proporção de anticorpos no soro de pacientes com doença meningocócica pode ser adsorvido pela proteína de membrana externa de $N$. lactamica. Antígenos de N. lactamica parecem proteger camundongos contra infecção meningocócica experimental (Gorringe et al., 2000). O uso de vacinas baseadas em vesículas de 
membrana externa de $N$. lactamica pode oferecer uma potencial proteção contra a doença meningocócica (Alonso, 2003).

Foi produzida uma vacina de OMV de meningococo B pelo Walter Army Institute of Research, que contém altas concentrações de lipooligossacarídeos (LOS). Esta vacina administrada intranasalmente em adultos têm se mostrado pouco reatogênica e tem induzido o aparecimento de anticorpos bactericidas, alguns contra cepas heterólogas, dirigidos fundamentalmente contra a porina A e ao LOS. Simultaneamente, nos vacinados houve um aumento de títulos de imunoglobulinas $\lg A$ e $\lg G$ específica intranasal. Também está sendo estudada uma vacina variante de mucosa pelo National Institute of Public Health da Noruega em adultos num regime de quatro doses com intervalos semanais que tem induzido respostas específicas de células $T$.

Atualmente, uma vacina de OMV se encontra em fase de desenvolvimento pelo Center for Applied Microbiology and Research do Reino Unido. Outra perspectiva se vislumbra com a aplicação de técnicas de DNA recombinante para atenuar as cepas dos meningococos sorogrupo B epidemiologicamente importantes e preparar uma vacina multivalente intranasal que traria vantagens indubitáveis como:

1. Independência de seu perfil de lipopolissacarídeo e de proteínas de membrana externa;

2. Manutenção da configuração original dos antígenos de superfície;

3. Expressão de antígenos que aparecem durante o crescimento em um hospedeiro;

4. Desencadear respostas imunes mucosas que interfiram com a colonização;

5. Não interferir com as respostas séricas e outros antígenos parentais (Tang et al., 1999)

\subsubsection{Vacinas compostas de OMVs de $N$. lactamica}

A proteção contra a doença meningocócica invasiva está associada com a presença de anticorpos no soro, os quais são bactericidas contra $N$. meningitidis e com lise mediada pelo complemento como mecanismo efetor. Estes anticorpos são requeridos progressivamente nos primeiros anos de vida, um período quando a taxa de portadores de meningococos é baixa, mas a taxa de Neisserias comensais é alta. 
Então está esclarecido que a aquisição da imunidade natural em crianças pequenas pode seguir da colonização da nasofaringe pelas espécies não patogênicas de Neisseria e algumas outras bactérias expressando antígenos de reatividade cruzada imunologicamente compartilhados com os meningococos. $N$. lactamica é uma espécie comensal que não que não possui cápsula de polissacárides ou PorA mas compartilham muitos antígenos comuns com N. meningitidis .

O pico da taxa de portadores (aproximadamente $20 \%$ ) para $N$. lactamica que coloniza crianças numa faixa etária de zero a quatro anos de idade, parece reduzir a incidência da doença meningocócica em crianças mais velhas (Gorringe, 2005).

Um estudo realizado por Gold et al. (1978), demonstrou que $66 \%$ dos portadores de $N$. lactamica estudados desenvolveram anticorpos com atividade bactericida para meningococos dos sorogrupos A, B e C. Estas investigações sugerem que a indução de anticorpos contribui para o desenvolvimento da imunidade natural contra a doença meningocócica. Em adição, a presença de anticorpos humanos que reagem com proteínas conservadas e epítopos de LOS comuns entre N.lactamica e N.meningitidis podem levar a proteção contra a doença meningocócica, principalmente durante os primeiros anos de vida (Pollard \& Frasch, 2001). Estudos recentes demonstram a resposta de anticorpos de reatividade cruzada produzida por $N$. lactamica dirigidos contra os meningococos, e a eficácia da proteção de uma formulação de uma vacina experimental de $N$. lactamica contra a infecção meningocócica (Oliver et al., 2002). Estes estudos têm demonstrado que as vacinas compostas por antígenos de N.lactamica protegem contra a doença meningocócica em modelos murinos. Uma vez que $N$. lactamica e $N$. meningitidis não possuem PorA potencialmente capazes para a proteção subtipo específica. A proteção observada contra os isolados de diversos meningococos de linhagem clonais representativamente diferentes entre os sorogrupos B e C, dão evidências de que $N$. lactamica pode ter um potencial promissor para a produção de uma vacina subtipo específica independente contra a doença meningocócica. Tal vacina pode ser baseada em OMVs e então aumentar a segurança, imunogenicidade e eficácia assim como as vacinas de OMV de meningococos disponíveis (Gorringe, 2005). 
OMVs de N. lactamica têm sido preparadas e usadas para imunizar animais de laboratório (camundongos e coelhos). Anticorpos que tem reatividade cruzada com $N$. meningitidis em western blots têm sido demonstrados, mas a atividade bactericida contra $N$. meningitidis não foi observada. Em adição, um esquema de imunização com duas doses com OMV de $N$. lactamica seguida de um booster com OMV de meningococos produziu um aumento da atividade bactericida quando comparado com três doses de OMV de $N$. lactamica ou uma única dose de OMV de $N$. meningitidis, indicando que $N$. lactamica pode sensibilizar as células do sistema imune para uma resposta de reatividade cruzada a $N$. meningitidis. Observações ainda mais interessantes sobre a atividade de anticorpos de reatividade cruzada, foram que a adsorção do soro de um paciente convalescente de doença meningocócica com $N$. lactamica aboliu completamente a atividade bactericida contra a cepa infectante.

Uma clara evidência sobre o potencial de uma vacina baseada em $N$. lactamica foi proveniente do estudo de Oliver et al., (2002) que demonstraram que a imunização com whole cells de $N$. lactamica mortas, OMVs, ou pools de proteínas de membrana externa protegeram camundongos contra o desafio letal por vários isolados de diversos meningococos sorogrupos $\mathrm{B}$ e $\mathrm{C}$ em um modelo de infecção por bacteremia. No entanto, não foi demonstrado a resposta de anticorpos bactericidas contra $N$. meningitidis, indicando que outros mecanismos possam estar envolvidos nesta proteção. Uma resposta de anticorpos que medeiam opsonofagocitose tem sido observada em coelhos imunizados com OMVs de $N$. lactamica, sugerindo que este mecanismo possa estar envolvido em uma resposta protetora. A proteção na ausência de anticorpos bactericidas tem sido observada por outros antígenos, como com as IRPS (TbpA) e a vacina derivada do genoma 2132 candidata, demonstrando que anticorpos bactericidas podem não ser o único fator de proteção para as vacinas baseadas em proteínas de meningococos. O papel da LOS na observação de proteção ainda não está claro. LOS de $N$. lactamica purificados não protegeram contra o desafio com meningococos, mas é possível que as vacinas experimentais contendo LOS em várias quantidades e talvez em uma forma nativa e mais imunogênica do que os antígenos de LOS purificados possam ser promissores. 
Ainda mais, o fracionamento do pools de antígenos por eletroforese neste estudo demonstrou proteção contra o desafio por meningococos pelas frações que continham relativamente um pouco de LOS, indicando que outros antígenos protéicos possam ser ao menos parcialmente responsáveis pela proteção observada.

Subseqüentes estudos usando um modelo de proteção ativa e passiva em camundongos desafiados, cepas não meningocócicas foram testadas e não foram protetoras contra a resposta imune induzida por $N$. lactamica.

Um recente estudo demonstrou que OMVs de $N$. lactamica são também efetivas na geração de resposta imune de reatividade cruzada em camundongos quando administrados pela via intranasal. Em adição, estas OMVs são efetivas adjuvantes intranasais, aumentando grandemente a resposta de anticorpos quando foi coadministrado com antígenos de superfície da hepatite B. Em concordância com os estudos de Oliver e colaboradores (2002), os anticorpos de atividade bactericida não foram observados seguindo-se a imunização com OMVs de N. lactamica, mas a proteção foi observada em um modelo de camundongos neonatos quanto a bacteremia meningocócica. Ainda mais, interessantes observações quanto às vacinas de OMV de $N$. lactamica foram feitas em outro estudo, no qual proteínas Opa de OMVs de meningococos interagiram com CEACAM1 de células de linfócitos CD4+ a qual levou a respostas de supressão, ativação, proliferação e indução de apoptose. A vacina de OMV examinada no mesmo sistema in vitro não induziu supressão ou apoptose. Mais evidências do potencial da vacina de Neisseria comensal foi fornecida por O'Dwyer e colaboradores (2004), que estudaram uma proteína heteróloga de alto nível de expressão de uma vacina candidata NspA de meningococos, numa outra espécie de Neisseria comensal, $N$. flavences. NspA foi expressa em OMVs produzidas desta bactéria recombinante, e o anti-soro aumentou os mediadores de opsonofagocitose e proteção passiva em modelos de camundongos neonatos para a bacteremia meningocócica. Este desenvolvimento demonstra o potencial de OMVs de Neisseria comensais como um sistema de distribuição para antígenos heterólogos.

$N$. lactamica produz em sua superfície de membrana blebs ou vesículas da mesma forma que $N$. meningitidis, desta forma, pode ser possível a produção de OMVs de $N$. lactamica usando os métodos já publicados para as vacinas de OMV meningocócicas 
(Coen et al., 2000). As OMVs descritas por Oliver et al. (2002), foram produzidas de $N$. lactamica crescidas em meio com restrição de ferro através da adição do ácido quelador de ferro ethylenediaminedihy-droxyphenylacetic (EDDHA) e meio sem restrição de ferro. Como este é um componente não utilizado normalmente na indústria de manufatura farmacêutica, a proteção produzida por OMVs com restrição de ferro foi comparada em modelos de camundongos. Os camundongos foram imunizados com três doses de OMVs de $N$. lactamica preparados em meio de cultura com restrição de ferro ou sem restrição de ferro, sendo que em ambos os meios de cultura ofereceram equivalente proteção no modelo de infecção em camundongos, então a OMV produzida em meio sem restrição de ferro também pode ser usado (Gorringe et al., 2005b).

A imunização com OMVs de $N$. lactamica protegeu os camundongos que receberam um desafio letal intraperitoneal com diversos isolados de meningococos, desta forma foi desenvolvida esta vacina que se encontra na fase 1 de segurança e imunogenicidade sendo já testada em voluntários humanos adultos.

Atualmente a vacina está sendo manufaturada e validada através de protocolos de ELISA que tem sido desenvolvido para a análise das respostas sorológicas (Gorringe et al., 2005b).

No estudo de Gorringe et al. (2005a), foi utilizado anticorpos monoclonais para caracterizar um grupo de 35 cepas de $N$. lactamica, nenhuma das cepas reagiram com anticorpos contra polissacarídeos capsulares de meningococos e/ou Por A, e somente duas das cepas reagiram com anticorpos PorB. No entanto, muitas das cepas de $N$. lactamica ligaram-se a um ou mais lipooligossacarídeos (LOS) específicos para os monoclonais utilizados.

Baseados nestes estudos, os autores especularam que os epitopos compartilhados de LOS podem desempenhar um importante papel no desenvolvimento da imunidade natural aos meningococos. O papel que LOS desempenham na produção de anticorpos de reatividade cruzada têm sido estudado e discutido em trabalhos adicionais. A utilização da técnica de Immunoblot tem identificado vários antígenos de membrana externa de reatividade cruzada, incluindo o antígeno H8 e LOS. Vários antígenos de meningococos que fornecem proteção em modelos animais e/ou induzem 
anticorpos de atividade bactericida também estão presentes em N. lactamica, e podem ser parcialmente responsáveis pela indução de uma resposta que pode proteger contra a doença meningocócica. Estes incluem as transferrinas de ligação de proteínas: NspA, NadA, lipoproteína 2086 e vários outros antígenos, identificados pela vacinologia reversa do genoma do meningococo sorogrupo B (Kelly \& Rappuoli, 2005).

\subsection{Avidez de anticorpos}

Durante a reação imune, as respostas celulares primárias produzem anticorpos IgM de baixa afinidade. Com a progressão da resposta imune, a maturação das células B toma lugar, aumentando a sua afinidade pelo antígeno. Ocorre então um "switch" de classe de $\operatorname{lgM}$ para lgG, fenômeno que exige a seleção de clones celulares de alta afinidade com maior capacidade de reconhecimento de agentes externos (Granoff et al., 1998). Em alguns casos a quantidade de anticorpos bactericida se torna limitada, como no caso de crianças menores de dois anos de idade que recebem vacinas antimeningocócicas polissacarídicas. Além disso, existem dificuldades envolvidas no desenvolvimento dos ensaios para a avaliação da atividade bactericida dos soros, incluindo variação dos resultados dependente da cepa utilizada, condições de crescimento bacteriano e fonte de Complemento.

Granoff et al. (1998), desenvolveram um ensaio de ELISA no qual utilizando o tiocianato de potássio ( $\mathrm{KSCN}$ ) como componente caotrópico, foram capazes de medir as concentrações de anticorpos anti-capsulares para o meningococo $\mathrm{C}$. Os resultados da capacidade de ligação dos anticorpos produzidos por indivíduos imunizados, medida no ensaio de avidez apresentou correlação linear com a atividade bactericida nos soros. Diferentes substâncias caotrópicas podem ser utilizadas em diferentes concentrações e $\mathrm{pH}$, capazes de causar alterações na força iônica das ligações antígeno-anticorpo, determinando a eluição de ligações fracas, ou seja, de baixa avidez, enquanto moléculas com alta força de ligação não são eluídas.

Devido à característica de maturação das células $\mathrm{B}$, o ensaio de avidez é muito útil para a diferenciação entre as respostas imunes primárias e secundárias. Testes de avidez de IgG têm sido utilizados para o diagnóstico de infecções virais, para a 
discriminação entre infecções primárias e reinfecções ou reativações e ainda, para se estimar a eficácia ou falhas vacinais (Narita et al., 1998; de Souza et al., 2004).

Vermont et al. (2002), utilizando KSCN 1,5M para a análise do índice de avidez de anticorpos IgG para anticorpos produzidos por uma vacina OMV de meningococo $B$ verificaram altos títulos de anticorpos de alta avidez que se correlacionaram fortemente com a atividade bactericida.

Soenawan et al. (2004), estudaram os mecanismos envolvidos na resposta imunológica, após imunizações pela via oral versus imunização pela via intramuscular com a toxina colérica em camundongos. Os autores utilizaram o tiocianato de amônia a $4 \mathrm{~N}$ e observaram uma variação nos índices de avidez de acordo com a fase da resposta imune. No entanto, após a imunização oral os anticorpos persistentes de maior avidez pertenciam ao isótipo IgM, sugerindo ser este isótipo importante na manutenção da memória imunológica.

Fukasawa et al. (2004), em imunizações de camundongos neonatos com duas formulações de vacina OMV contra os meningococos $B$ e $C$, verificaram se alguns adjuvantes que atualmente estão em testes em humanos tais como MPL (Monofosforil Lípide A), "Titermax" e MF59 (Monofosforil 59), seriam capazes de indução a produção de anticorpos do isótipo lgG de alta avidez. Os autores puderam concluir que a utilização do adjuvante MF59 foi capaz de aumentar a resposta induzida por vacinas OMVs contra o meningococo $\mathrm{B}$ e os anticorpos apresentaram acentuada funcionalidade quando medidos por meio de ELISA utilizando o tiocianato de potássio 1,5 M como agente caotrópico.

Usinger \& Lucas (1999) compararam o índice de avidez e a atividade de opsonização de anticorpos lgG2 produzidos em soros de camundongos imunizados contra S. pneumoniae dos sorotipos $6 \mathrm{~B}$ e $23 \mathrm{~F}$, verificando que houve uma correlação inversa entre a magnitude da resposta e a quantidade de anticorpos necessários para proteger os camundongos de uma bacteremia letal, causada pelo sorogrupo 6B, demonstrando que anticorpos de maior avidez foram mais efetivos na destruição do pneumococo quando comparados com os de baixa avidez. 


\section{II - OBJETIVOS}

\section{$2.1 \quad$ Gerais}

O objetivo do presente estudo é avaliar a especificidade e capacidade protetora dos anticorpos por meio de atividade bactericida e avidez induzidos em coelhos imunizados pela via intranasal com bactérias íntegras (whole cells) de $N$. lactamica, $N$. sicca, N. meningitidis e N. Meningitidis isolada de carreador.

\section{$2.2 \quad$ Específicos}

- Estudo da produção de anticorpos dos isótipos IgG presentes nos soros de coelhos imunizados pela via intranasal.

- Estudo de anticorpos produzidos em coelhos para antígenos de N. meningitidis analisado por meio de ELISA e "Immunoblot".

- Estudo da reatividade cruzada por Immunoblot

- Avaliação da atividade de destruição de meningococos (atividade bactericida) dos anticorpos presentes nos soros de coelhos imunizados pelas vias intranasal.

- Avidez dos anticorpos produzidos 


\section{III - MATERIAIS E MÉTODOS}

\section{3a. Animais}

Foram utilizados 8 coelhos adultos albinos New Zealand (Tabela 1). Todos os animais provieram da empresa CRIEX e foram mantidos no Biotério Experimental do Instituto Adolfo Lutz São Paulo, SP. Todos os procedimentos com os animais estavam de acordo com os princípios do código brasileiro para o uso de animais de laboratório.

Tabela 1: Esquema experimental de imunização de coelhos

Imunização de coelhos com "whole cells" D.O: 1 a $650 \mathrm{~nm}$ pela via intranasal. Os coelhos receberam quatro doses das bactérias inativadas.

- N.L. - N. lactamica cepa 1024/94.

- N.M. - N. meningitidis cepa (44/89).

- N.S. - N. sicca cepa NSP10 (Espanha).

- N.Mc - N. meningitidis isolada de carreador, cepa P.391(A: P1. 9) Ferreirós (Espanha).

(Dia $0-1^{\mathrm{a}}$ dose; Dia $7-2^{\mathrm{a}}$ dose; Dia $14-3^{\mathrm{a}}$ dose; Dia $21-4^{\mathrm{a}}$ dose; Os coelhos foram sangrados no $35^{\circ}$ dia (após receberem quatro doses).

\begin{tabular}{|c|c|c|c|c|c|}
\hline & $\frac{1^{\mathrm{a}} \text { Dose }}{\text { Dia } 0}$ & $\frac{2^{\mathrm{a}} \text { Dose }}{\text { Dia } 7}$ & $\frac{3^{a} \text { Dose }}{\text { Dia } 14}$ & $\frac{4^{\mathrm{a}} \text { Dose }}{\text { Dia } 21}$ & $\frac{\text { Sangria Total }}{\text { Dia } 35}$ \\
\hline$\frac{\text { Coelho } 1}{\text { Antígeno }}$ & $\mathrm{NL}$ & $\mathrm{NL}$ & $\mathrm{NL}$ & $\mathrm{NL}$ & \\
\hline Peso & $3100 \mathrm{~g}$ & $3250 \mathrm{~g}$ & $3350 \mathrm{~g}$ & $3200 \mathrm{~g}$ & $3800 \mathrm{~g}$ \\
\hline Numero & 331 & & & & \\
\hline$\frac{\text { Coelho } 2}{\text { Antígeno }}$ & $\mathrm{NL}$ & $\mathrm{NL}$ & NM & NM & \\
\hline Peso & $3000 \mathrm{~g}$ & $3400 \mathrm{~g}$ & $3650 \mathrm{~g}$ & $3800 \mathrm{~g}$ & $3850 \mathrm{~g}$ \\
\hline Numero & 335 & & & & \\
\hline$\frac{\text { Coelho } 3}{\text { Antígeno }}$ & NS & NS & NS & NS & \\
\hline Peso & $2900 \mathrm{~g}$ & $3400 \mathrm{~g}$ & $3200 \mathrm{~g}$ & $3250 \mathrm{~g}$ & $3500 \mathrm{~g}$ \\
\hline Numero & 334 & & & & \\
\hline$\frac{\text { Coelho } 4}{\text { Antígeno }}$ & NS & NS & NM & NM & \\
\hline Peso & $2980 \mathrm{~g}$ & $3400 \mathrm{~g}$ & $3650 \mathrm{~g}$ & $3630 \mathrm{~g}$ & $3750 \mathrm{~g}$ \\
\hline Numero & 328 & & & & \\
\hline$\frac{\text { Coelho } 5}{\text { Antígeno }}$ & NM (C) & NM (C) & NM (C) & NM (C) & \\
\hline Peso & $2900 \mathrm{~g}$ & $2900 \mathrm{~g}$ & $3250 \mathrm{~g}$ & $3350 \mathrm{~g}$ & $3600 \mathrm{~g}$ \\
\hline Numero & 333 & & & & \\
\hline
\end{tabular}




\begin{tabular}{|c|c|c|c|c|c|}
\hline$\frac{\text { Coelho } 6}{\text { Antígeno }}$ & NMc & NMc & NM & NM & \\
\hline Peso & $2250 \mathrm{~g}$ & $2750 \mathrm{~g}$ & $2950 \mathrm{~g}$ & $3300 \mathrm{~g}$ & $3400 \mathrm{~g}$ \\
\hline Numero & 330 & & & & \\
\hline$\frac{\text { Coelho } 7}{\text { Antígeno }}$ & NM & NM & NM & NM & \\
\hline Peso & $3000 \mathrm{~g}$ & $3200 \mathrm{~g}$ & $3350 \mathrm{~g}$ & $3420 \mathrm{~g}$ & $3500 \mathrm{~g}$ \\
\hline Numero & 337 & & & & \\
\hline$\frac{\text { Coelho } 8}{\text { Antígeno }}$ & NM & NM & $\mathrm{NL}$ & NL & \\
\hline Peso & $3100 \mathrm{~g}$ & $3050 \mathrm{~g}$ & $3100 \mathrm{~g}$ & $3400 \mathrm{~g}$ & $3300 \mathrm{~g}$ \\
\hline Numero & 332 & & & & \\
\hline
\end{tabular}

\section{3b. Cepas de bactérias}

A cepa de $N$. meningitidis B: 4,7: P1.15,19 (44/89) utilizada foi gentilmente cedida pela Dra. Cecília O. Gorla, da Seção de Bacteriologia do Instituto Adolfo Lutz. Esta cepa foi escolhida para nossas investigações por ser prevalente em nosso país e foi obtida de paciente portador de doença meningocócica.

As cepas de $N$. lactamica foram isoladas da orofaringe de carreadores saudáveis na nossa comunidade. As cepas comensais foram: N. lactamica, N. subflava, $N$. perflava, N.elongata, N. sicca, N.mucosa, isoladas do liquido espinhal ou sangue na Seção de Bacteriologia do Instituto Adolfo Lutz. Nós também usamos cepas de $N$. lactamica, N. sicca e N. meningitidis isoladas da orofaringe que também foram gentilmente cedidas pela Dra. Ana Paula Lemos ou cepas gentilmente fornecidas pelo Dr. Ferreirós do Departamento de Microbiologia e Parasitologia da Espanha (Tabela 2). As cepas comensais e cepas de $N$. meningitidis foram cultivadas em ágar-sangue contendo $1 \%$ de sangue de cavalo. As cepas foram mantidas a temperatura de $-70^{\circ} \mathrm{C}$ em uma solução de leite desnatado ou foram liofilizadas e estocadas a $4^{\circ} \mathrm{C}$. As cepas cresceram sobre placas de Petri contendo ágar-soro preparado com base ágar-soja e trypticaseina (TSB Difco Laboratories Detroit, MI, EUA), enriquecido com 1\% de soro de cavalo (Sigma Chemical Company, St. Louis, MO, EUA) e incubados a $37^{\circ} \mathrm{C}$ em jarra com atmosfera de $5 \%$ de $\mathrm{CO}_{2}$. 
Tabela 2. Cepas de gênero Neisseria isoladas do sangue, LCR ou Orofaringe durante os anos de 1990-2000 na Seção de Bacteriologia do Instituto Adolfo Lutz e da Espanha.

\begin{tabular}{|c|c|c|}
\hline Cepas & Local & \\
\hline N $44 / 89$ & LCR & N. meningitidis $B$ \\
\hline N $360 / 88$ & LCR & N. meningitidis $B$ \\
\hline N 456 / 99 & LCR & N. subflava subflava \\
\hline N 699 / 99 & LCR & N. elongata \\
\hline N 613 / 98 & LCR & N. subflava perflava \\
\hline N $799 / 98$ & LCR & N. lactamica \\
\hline $\mathrm{N} 20 / 00$ & LCR & N. subflava perflava \\
\hline N 44 / 00 & LCR & N. mucosa \\
\hline N $123 / 00$ & LCR & N. subflava flava \\
\hline N $148 / 00$ & LCR & N. subflava perflava \\
\hline N 926 / 99 & Sangue & N. sicca \\
\hline N $1398 / 00$ & Orofaringe & N. lactamica \\
\hline N 831/98 & Orofaringe & N. lactamica \\
\hline N 844/95 & Orofaringe & N. lactamica \\
\hline N 602 / 91 & Orofaringe & N. lactamica \\
\hline N 362 / 92 & Orofaringe & N. lactamica \\
\hline N 852 / 93 & Orofaringe & N. lactamica \\
\hline N 952 / 93 & Orofaringe & N. lactamica \\
\hline N 1024 / 94 & Orofaringe & N. lactamica \\
\hline N 924 / 93 & Orofaringe & N. lactamica \\
\hline N 124 / 94 & Orofaringe & N. lactamica \\
\hline N $124 / 96$ & Orofaringe & N. lactamica \\
\hline N IP4 & Orofaringe & N. lactamica - (Espanha) \\
\hline NSP10 & Orofaringe & N. sicca - (Espanha) \\
\hline N 391 & $\begin{array}{l}\text { Orofaringe } \\
\text { (carreador) }\end{array}$ & N. meningitidis $B-$ (Espanha) \\
\hline
\end{tabular}

3c. Preparo da suspensão de células bacterianas íntegras ("whole-cells") de $\boldsymbol{N}$. meningitidis e outras espécies do gênero Neisseria

A partir do crescimento em ágar-chocolate base "Müeller-Hinton" as cepas selecionadas foram semeadas em placas de Petri com $15 \mathrm{~cm}$ de diâmetro descartáveis (Costar, Cambridge, MA, EUA), como descrito anteriormente. Após crescimento de aproximadamente 18 horas a $37^{\circ} \mathrm{C}$, foi preparada uma suspensão bacteriana com 0 objetivo de se obter uma concentração correspondente a D.O. = 1,0 em comprimento de onda de 650 nm (CELM - modelo E2250) diluídas em PBS com 0,02\% de azida sódica. Após crescimento, cada preparação bacteriana foi analisada pelo método de 
Gram para verificarmos o grau de pureza das preparações. As suspensões de células bacterianas íntegras foram agrupadas de acordo com as cepas selecionadas, separadamente em tubos Falcon (Costar, Cambridge, MA, EUA) e acondicionadas em geladeira a $4^{\circ} \mathrm{C}$.

\section{3d. Obtenção de anticorpos policlonais}

Para obtenção de anticorpos policlonais anti-whole cells de N. meningitidis, N.lactamica, N.sicca ou N.meningitidis isolada de carreador utilizamos coelhos. Empregou-se, para inoculação, a porta de entrada da bactéria: a via intranasal. Os grupos de animais imunizados pela via intranasal receberam os antígenos por instilação sem a presença de adjuvantes. O protocolo utilizado para imunização pela via intranasal está descrito na tabela 3.

Tabela 3. Esquema experimental de imunização de coelhos.

\begin{tabular}{|c|c|}
\hline Dia 0 & $1^{\text {a }}$ dose \\
\hline Dia 7 & $2^{\text {a }}$ dose \\
\hline Dia 14 & $3^{\text {a }}$ dose \\
\hline Dia 21 & $4^{\text {a }}$ dose \\
\hline Dia 35 & Sangria total \\
\hline
\end{tabular}

Imunização de coelhos com "whole cells" D.O: 1 a $650 \mathrm{~nm}$ pela via intranasal. Os coelhos receberam quatro doses das bactérias inativadas.

- N.L. - N. lactamica cepa $1024 / 94$.

- N.M. - N. meningitidis cepa 44/89.

- N.S. - N. sicca cepa NSP10 (Espanha)

- N.Mc - N. meningitidis isolada de carreador, Cepa P.391 (Espanha)

Os soros dos coelhos foram obtidos por sangria da veia central da orelha antes da imunização e no dia $45^{\circ}$ dia por punção cardíaca (sangria branca).

\section{3e. Eletroforese em gel de poliacrilamida (SDS-PAGE)}

Os antígenos de $N$. meningitidis utilizados em nossos estudos foram analisados por eletroforese em gel de poliacrilamida na presença de dodecil sulfato de sódio (SDS), 13\%, sob condições redutoras, em sistema descontínuo seguindo-se o procedimento descrito por Laemmli et al., 1970. 


\section{3f. Métodos de coloração utilizados}

"Coomassie Blue"

Para a caracterização protéica empregando-se a coloração por "Coomassie blue" as amostras foram preparadas utilizando $20 \mu \mathrm{L}$ de células bacterianas íntegras, D.O.= 1,0 em comprimento de onda de $650 \mathrm{~nm}$ (CELM - modelo E2250). Em 20 $\mathrm{LL}$ de tampão de amostra (62,5 mM de Tris-hydrochloride, $\mathrm{pH} 6,8,1 \%(\mathrm{v} / \mathrm{v})$ glicerol, $2 \%$ de água destilada e 0,5\% de SDS a 10\% (v/v) e $5 \mu \mathrm{L}$ de azul de bromofenol (Sigma Chemical Company, St. Louis, MO, EUA).

Após a corrida eletroforética o gel foi colocado em solução fixadora constituída de metanol a 50\% e ácido acético a 10\% durante 20 minutos à temperatura ambiente e corado por Coomassie Phast blue - R250 (Pharmacia LKB, Biotechnology, Piscataway, New Jersey, EUA) a $56^{\circ} \mathrm{C}$ por 1 hora. Em seguida, o gel foi descorado com várias trocas de ácido acético glacial a $7 \%$ a $56^{\circ} \mathrm{C}$.

Aplicamos juntamente com as amostras um padrão de proteínas com peso molecular conhecido (Pharmacia LKB, Biotechnology, Piscataway, New Jersey, EUA) ou BioRad (14-200kDa). Os padrões de peso molecular Pharmacia LKB usados foram: fosforilase b (94kDa); albumina bovina (67 kDa); ovalbumina (43 kDa); anidrase carbônica (30 kDa); inibidor de tripsina (20 kDa) e alfa-lactoalbumina (14kDa). Os pesos moleculares (P.M.) das bandas foram determinados a partir da reação linear entre o log do P.M. e migração relativa (R.F.) de proteínas-padrão. Depois de preparadas, as amostras foram aquecidas por 5 minutos a $100^{\circ} \mathrm{C}$.

\section{3g. "Immunoblotting"}

Para realização do ensaio de "Immunoblotting"; após a eletroforese, o gel foi retirado cuidadosamente das placas e incubado em tampão de transferência (Trishidroximetilaminometano $25 \mathrm{mM}$, glicina $192 \mathrm{mM}$ e metanol 20\%, pH 8,3) por 20 minutos. Foi feito um sanduíche com 3 folhas de papel de filtro ( 2 folhas de papel de filtro $\mathrm{n}^{0} 2$ e uma folha de papel de filtro $\mathrm{n}^{0} 1$ (Watman, $\mathrm{n}^{0} 1$, EUA)), a membrana de nitrocelulose, o gel e mais uma seqüência 3 folhas de papel de filtro, todas previamente embebidas em tampão de transferência. Os peptídeos separados por SDS-PAGE foram transferidos do gel, para membrana de nitrocelulose, segundo metodologia descrita por 
Towbin et al., 1979. A transferência foi realizada por um período de 18 horas a $50 \mathrm{~mA}$ e voltagem constante de $17 \mathrm{~V}$. Em seguida, a membrana foi corada com Ponceau-S a 0,5\% (Sigma Chemical Company, St. Louis, MO, EUA) para controle da transferência. Após secagem, as membranas foram envolvidas em papel de filtro, vedadas em saco plástico e armazenadas a $4^{\circ} \mathrm{C}$, até o momento do uso, e foram utilizadas no máximo até uma semana após realizada a transferência eletroforética.

Depois da transferência, as membranas de nitrocelulose foram lavadas sob agitação constante com PBS pH 7,4 para então se efetuar o bloqueio dos sítios ativos com leite desnatado 5\% (Glória do Brasil) diluído em PBS por 2 horas. Foram feitas novas lavagens com PBS após o bloqueio e, em seguida, a incubação de 15-18 horas com as amostras de anti-soros obtidos de animais dos grupos dos animais imunizados pela via intranasal foram diluídos a 1:50. No dia seguinte as membranas foram lavadas mais cinco vezes com PBS pH 7,4 e adicionou-se conjugado específico antiimunoglobulina de coelho IgG conjugado biotina. Sigma Chemical Company, St. Louis, MO, EUA) e incubadas por um período de mais de 2 horas. Após lavagem as membranas foram incubadas com biotina-peroxidase à 1:2000. Após sucessivas lavagens foi adicionado o substrato AEC (Pierce) 2,6 mL AEC à $4 \%+40 \mathrm{~mL}$ de solução de acetato de sódio, pH 5,0 (Sigma Chemical Company, St. Louis, MO, EUA)). A reação enzimática foi interrompida com água bi-destilada.

\section{3h. ELISA}

O procedimento utilizado foi baseado na técnica de Abdillahi \& Poolman, 1988. Placas de microtitulação de fundo chato (Polysorb - Costar, Cambridge, MA, EUA) foram sensibilizadas com $100 \mu \mathrm{L}$ da suspensão de bactérias mortas com azida sódica a 0,02\% (suspensão de células bacterianas íntegras) das cepas de $N$. meningitidis, N.lactamica, $N$ sicca ou N.meningitidis isoladas da orofaringe numa concentração de D.O. $=1,0$ a $650 \mathrm{~nm}, 18$ horas a $37^{\circ} \mathrm{C}$. Depois da incubação, foi feita a lavagem com PBS/Tween a 0,05\% e, a seguir, os sítios ativos das placas foram bloqueados com 200 $\mu \mathrm{L}$ por cavidade com leite desnatado a $5 \%$ (Glória, do Brasil) a $37^{\circ} \mathrm{C}$ por 2 horas. As placas foram novamente lavadas cinco vezes por 5 minutos com PBS/Tween a 0,05\%. As amostras de soros de coelhos foram diluídas na razão 2, a partir de 1:500 e 
adicionado num volume de $100 \mu \mathrm{L}$ por cavidade e incubadas à $37^{\circ} \mathrm{C}$ por duas horas. Em seguida, mais uma lavagem foi feita com PBS/Tween a 0,05\% e, posteriormente, foram adicionados $100 \mu \mathrm{L}$ por cavidade de anticorpos anti-IgG. Diluídos a 1:5. 000, previamente padronizados pela titulação em bloco. As placas foram incubadas com esses conjugados a $37^{\circ} \mathrm{C}$ por 2 horas e, posteriormente, lavadas e reveladas com 100 $\mu \mathrm{L}$ por cavidade de solução cromógena contendo $250 \mu \mathrm{L}$ de $\mathrm{TMB}, 12,5 \mathrm{~mL}$ de citrato $+2,5 \mathrm{~mL}$ de $\mathrm{H}_{2} \mathrm{O}_{2}$ (30\%) por um período de 20 minutos. A reação enzimática foi interrompida com $100 \mu \mathrm{L}$ de solução de $\mathrm{H}_{2} \mathrm{SO}_{4}, 1 \mathrm{~N}$. Foram consideradas positivas as amostras com leitura das absorbâncias (DO) maiores que os títulos mais altos apresentados pelos soros pré-imunes. Para auxiliar no entendimento dos resultados, empregou-se a razão entre os valores das amostras e um valor dos soros pré-imunes. Os limiares de reatividade foram determinados para cada coelho para a detecção de anticorpos das classes IgG induzidas pela via intranasal, com o intuito de se obter a máxima descrição de reatividade com whole cells de $N$. meningitidis e os diferentes gêneros de Neisseria utilizados neste estudo. Os anticorpos IgG induzidos pela via intranasal, foram determinados por meio de ELISA e o cutoff foi determinado como sendo o maior valor dos anticorpos presentes em pool de soros pré imunes. Para os soros imunes, a reatividade foi considerada para todos os valores acima desse limiar de reatividade.

\section{3i. Determinação do índice de avidez dos anticorpos}

O índice de avidez (IA) dos anticorpos dos isótipos IgG contra whole cells de $N$.meningitidis , $N$ lactamica, $N$ sicca ou N.meningitidis isoladas da orofaringe foi realizado de acordo com a metodologia estabelecida por Granoff et al. (1998), utilizando-se basicamente o mesmo procedimento utilizado para o ELISA com pequenas modificações.

O IA foi determinado de acordo com Vermont et al. (2002). A única modificação consistiu da incubação das placas com PBS, contendo tiocianato de potássio 1,5M (KSCN), que atuou como agente caotrópico nas reações. Nos ensaios os soros-teste foram incubados na ausência e na presença de KSCN. O índice de avidez foi expresso 
como a razão/ média das absorbâncias na presença de KSCN/ média das absorbâncias na ausência de KSCN (com PBS).

O seguinte critério foi estabelecido para a avaliação da avidez dos anticorpos anti-classe $5 \mathrm{C}$ ou anti-Bp ou anti-LPS ou anti-TC, de acordo com Chackerian et al. (2001) (tabela 4):

Tabela 4: Avaliação da avidez dos anticorpos

\begin{tabular}{|c|c|}
\hline Índices de avidez & Interpretação \\
\hline Acima de 0,50 & Anticorpos de alta avidez \\
\hline Entre $0,30-0,49$ & Anticorpos de avidez intermediária \\
\hline Abaixo de 0,29 & Anticorpos de baixa avidez \\
\hline
\end{tabular}

\section{3j. Atividade Bactericida}

- Fonte de complemento: Para a quantificação dos anticorpos nos soros de coelhos, utilizou-se como fonte de complemento soro de cobaio previamente padronizado diluído 1:2.

- Teste Bactericida: Os ensaios bactericidas foram realizados em placas de microtitulação de 96 cavidades de acordo com Borrow e Carlone (2001). A reação final continha $25 \mu \mathrm{L}$ dos soros em teste inativados por 30 minutos a $56^{\circ} \mathrm{C}$ e diluidos em diluição seriada de razão 2 em meio de Hanks ; 12,5 $\mu \mathrm{L}$ de suspensão bacteriana ( na concentração de aproximadamente de $3 \times 10^{3} \mathrm{ufc} / \mathrm{mL}$ ) crescida em meio de Brain Heart Infusion Agar(BHI-Difco) acrescido de soro de cavalo a $1 \%$ foi utilizada. A reação foi incubada por 30 minutos, conforme padronizado por Maslanka et al. (1997). Após a incubação, foram adicionados $130 \mu \mathrm{L}$ por cavidade de meio de Tryptic Soy Broth (TSB-Difco) contendo Agar Noble (Difco) a 0,9\%(p/v) e uma mistura de vancomicina, colistina e nistatina (VCN-Laborclin) a $0,15 \%(v / v)$. Deixou-se incubar as placas por 18 horas a $37^{\circ} \mathrm{C}$ em $5 \%$ de $\mathrm{CO}_{2}$. Com a finalidade de determinar a quantidade de UFCs 
referentes à $100 \%$ de sobrevivência, foram realizadas culturas quantitativas no tempo $0\left(T_{0}\right)$, antes da incubação das placas com complemento. Plaqueou-se $12,5 \mu \mathrm{L}$ da suspensão bacteriana $\left(3 \times 10^{3} \mathrm{ufc} / \mathrm{mL}\right)$ empregada no ensaio e deixouse incubar por 18 horas a $37^{\circ} \mathrm{C}$ em $\%$ de $\mathrm{CO}_{2}$. Foram incluídos em cada placa os seguintes controles:

- Para o controle da morte bacteriana dependente da ativação das vias alternativa reagiu-se a suspensão bacteriana e a fonte de complemento na ausência dos soros em teste.

- Para o controle da morte bacteriana independente do complemento reagiram-se os soros em teste e a suspensão bacteriana com a fonte de complemento inativado a $56^{\circ} \mathrm{C}$ por 30 minutos.

- Controle positivo, o qual consistia de um pool de soros de camundongos com títulos previamente determinados. Todos os soros em estudo foram testados em duplicata.O título bactericida foi definido como a recíproca da maior diluição do soro teste resultando em pelo menos $50 \%$ de morte bacteriana. 


\section{IV - RESULTADOS}

Os experimentos relatados a seguir foram realizados com soros de coelhos analisados individualmente. Os coelhos foram imunizados com whole cells de $N$. meningitidis $B$ da cepa 44/89 e 391 NMc e whole cells de bactérias do gênero Neisseria como $N$. lactamica cepa 1024/94 e a cepa de N. sicca NSP10 pela via nasal.

\section{4a- Caracterização imunoquímica das preparações antigênicas utilizadas :}

As cepas da Tabela 2 foram primeiramente caracterizadas imunoquímicamente por meio da separação protéica em gel SDS-PAGE 13\% e coloração por Coomassie Blue para verificar o perfil eletroforético dos whole cells. Com as cepas 44/89 de N.meningitidis, procedemos também à extração de NOMV e analisamos o perfil eletroforético. (De Gaspari, 2000b). 
A figura 4 mostra o perfil eletroforético de suspensão de células bacterianas integras whole cells de $N$ meningitidis, bactérias do gênero Neisseria e NOMV da cepa de $N$ mennigitidis coradas por Coomassie Blue onde podemos observar que as cepas analisadas apresentam antígenos na faixa de 10-200 kDa. As cepas analisadas apresentaram um padrão heterogêneo após coloração. Alguns antígenos se mostraram predominantes dependendo da cepa analisada. Diferentes preparações antigênicas caracterizadas por SDS-PAGE foram utilizadas para o estudo de antígenos de reatividade cruzada quando utilizamos os soros (anticorpos lgG) produzidos em coelhos com os diferentes esquemas de imunização pela via intranasal .

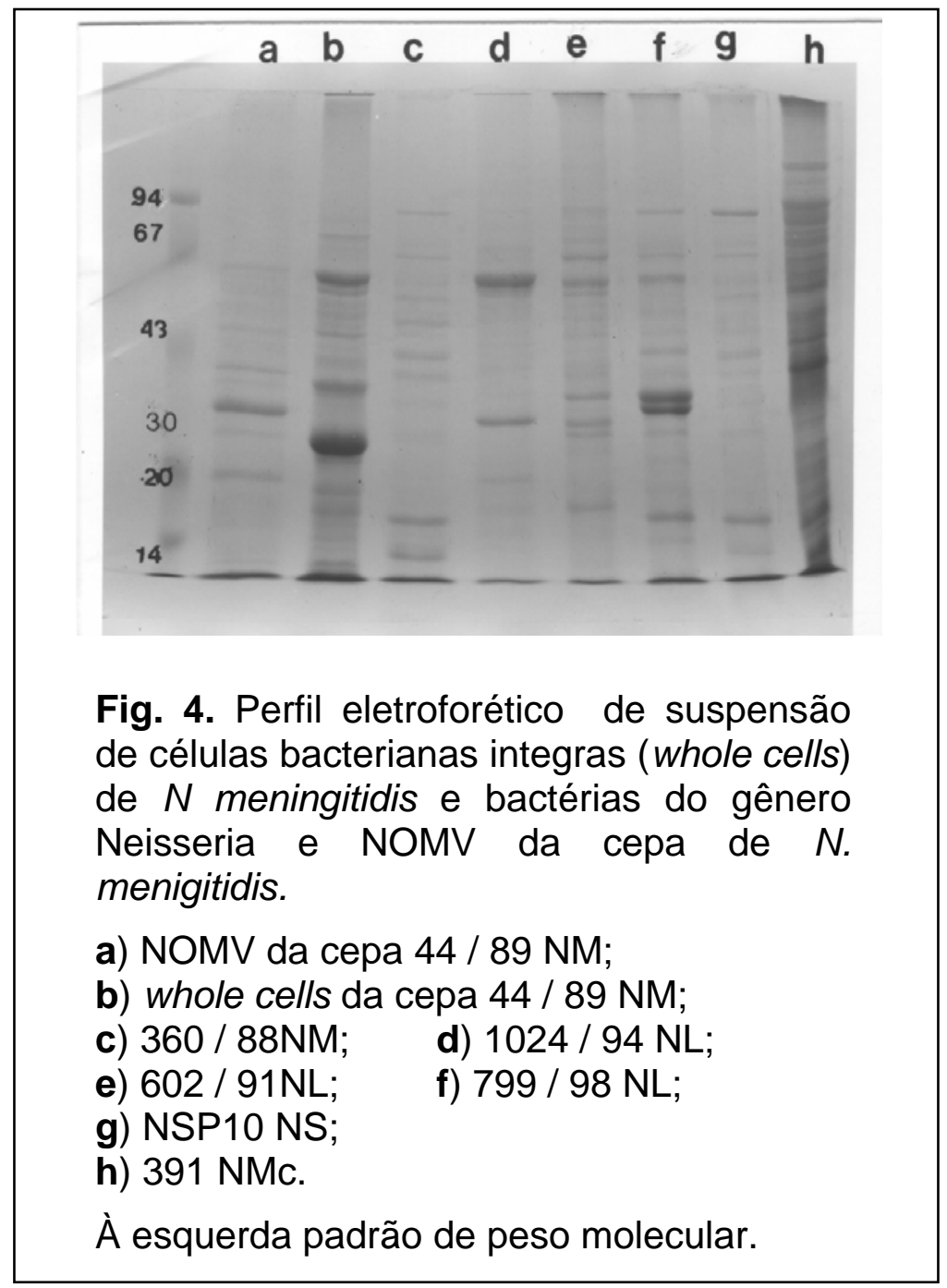




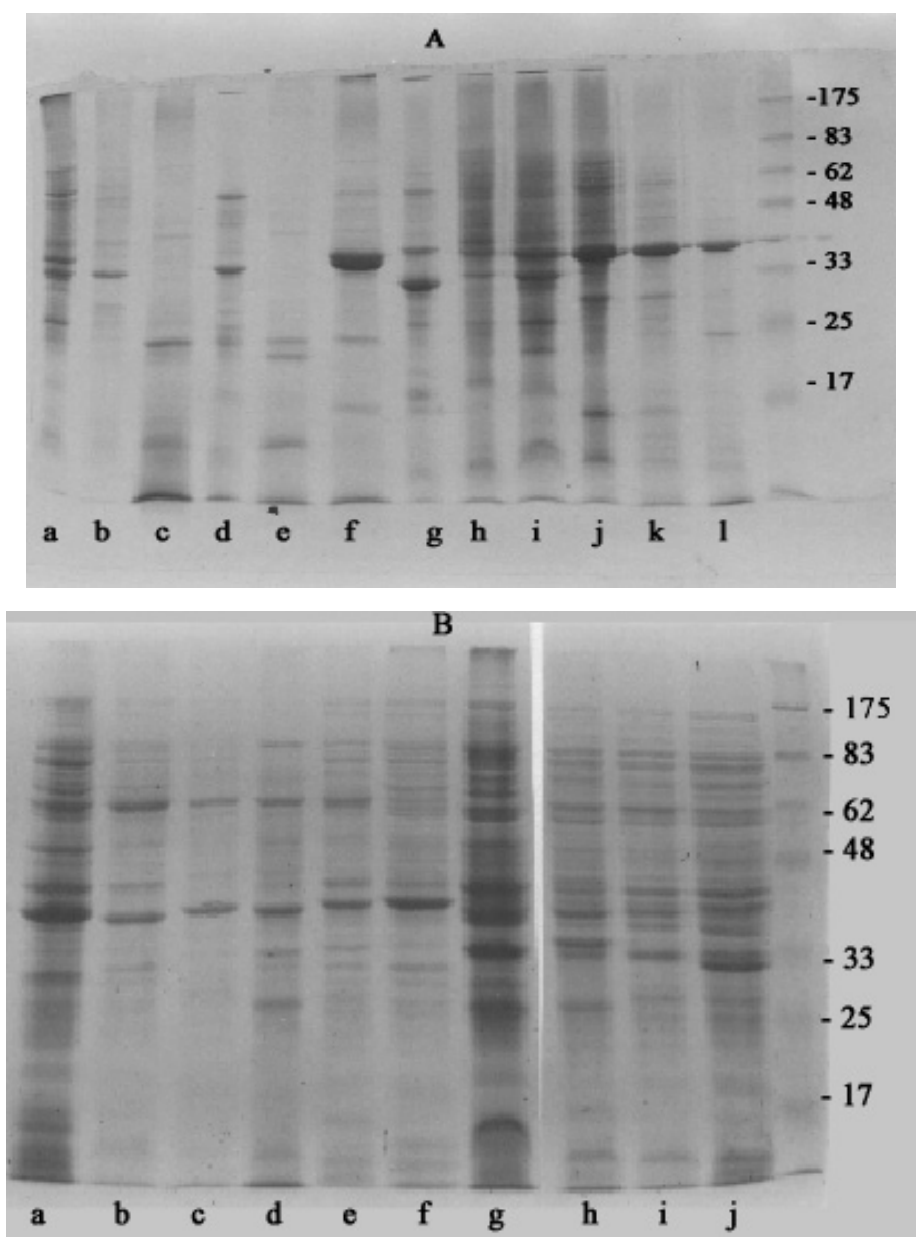

Fig. 5. Perfil eletroforético (SDS-PAGE) de suspensão de células bacterianas integras (whole cells) de $N$ meningitidis e bactérias do gênero Neisseria utilizada no Immunoblot para a reatividade com o anticorpo monoclonal 8C7Br1.

Gel A.
a) 602 / 91(NL);
d) 1024 / $94(\mathrm{NL})$;
g) $831 / 98(\mathrm{NL})$ j) 852 / $93(\mathrm{NL})^{*}$;

b) 362 / $92(\mathrm{NL})$;

e) 124 / $96(\mathrm{NL})$;

c) 124 / $94(\mathrm{NL})$;

h) 844 / $95(\mathrm{NL})$; f) 924 / $93(\mathrm{NL})$;

k) 952 / $93(\mathrm{NL})^{*}$;

i) $1398 / 00(\mathrm{NL}) *$;

Gel B.
a) 799 / $98(\mathrm{NL})$;
b) $44 / 00(\mathrm{Nm})$
d) 699 / 99 (NE);
g) $148 / 00$ (NSP);
e) $123 / 00$ (NF); j) $360 / 88$ (NM).
h) $20 / 00$ (NSP);
c) 456 / 99 (NS);
f) $613 / 98$ (NSP);
i) 44 / $89(\mathrm{NM})$;

l) $360 / 88(\mathrm{NM})$.

À direita padrão de peso molecular. 
A figura 5 mostra o perfil eletroforético de suspensão de células bacterianas integras (whole cells) de $N$ meningitidis e bactérias do gênero Neisseria coradas por Coomassie Blue, onde podemos observar que as cepas analisadas apresentam antígenos na faixa de $10-200 \mathrm{kDa}$. As cepas analisadas apresentaram um padrão heterogêneo após coloração. Alguns antígenos se mostraram predominantes dependendo da cepa analisada. Após a separação eletroforética as cepas foram utilizadas no estudo de reatividade com o anticorpo monoclonal 8C7Br1por meio de Immunoblot.

\section{4b- ELISA}

Os anticorpos dos isotipos IgG produzidos em coelhos imunizados pela via intranasal com bactérias integras foram quantificados, utilizando-se como antígeno whole cells de cepa de $N$. meningitidis, $N$. meningitis $c$, N.sicca e $N$. lactamica. As amostras de soros utilizadas foram obtidas de coelhos que foram individualmente imunizados.

\section{4.b.1. REATIVIDADE DE ANTICORPOS DO ISÓTIPO IgG PRESENTE NOS SOROS DE COELHOS IMUNIZADOS PELA VIA INTRANASAL COM QUATRO DOSES DE WHOLE CELLS DE N. LACTAMICA}

Por meio de ELISA pudemos observar que a concentração de anticorpos IgG produzidos pela via de imunização nasal foi diretamente dependente do whole cells da cepa selecionada e esquema de imunização utilizado como descrito na tabela 3 . As amostras analisadas foram obtidas após os coelhos receberem 4 doses de whole cells de $N$. lactamica.$O$ soro foi analisado no ( $35^{\circ}$ dia) após imunização.

A analise da figura 6 apresenta a reatividade de anticorpos IgG obtida do soro do coelho 1 mostra a reatividade homóloga e reatividade heteróloga de anticorpos do isótipo IgG de coelho com as diferentes cepas utilizadas. Neste estudo pudemos observar o soro dos animais após 4 doses de $N$. lactamica pela via i.n apresentou anticorpos que reagiram com whole cells de $N$. meningitidis, $N$. lactamica, $N$. sicca e $N$. meningidis $c$ mostrando assim uma grande homologia entre os antígenos presentes nas 
preparações antigênicas utilizadas. A análise do índice de incremento dos anticorpos IgG do coelho 1 imunizado com quatro doses de NL com os whole cells das cepas NM, NL, NS e NMc não apresentou uma diferença significativa. Os resultados sugerem que a imunização de coelho com quatro doses de whole cells de $N$. lactamica pode sensibilizar o sistema imune de mucosa induzindo a produção de anticorpos que reconheceram antígenos nas cepas analisadas por meio de Immunoblot. 

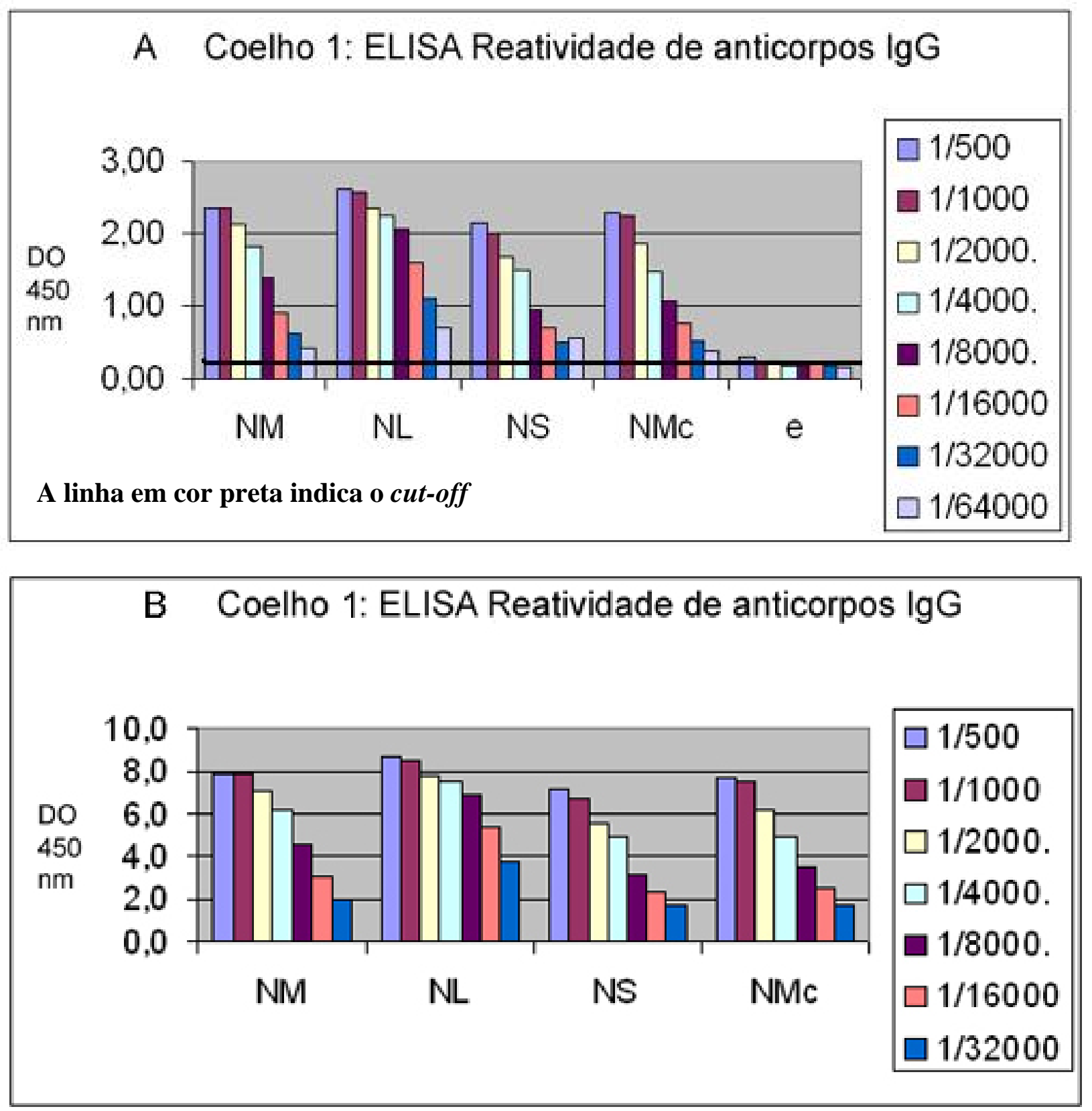

Figura 6 - (A) Estudo da produção de anticorpos lgG presentes no soro de coelhos imunizados com quatro doses de $N$. lactamica pela via intranasal. Reatividade com $N$. meningitidis e cepas do gênero Neisseria. Reatividade com as cepas (NM), (NL), (NS) e (NMc).

(B) Resultados da razão DO/média da recíproca dos títulos de anticorpos IgG contra antígenos de NM, NL, NS e MMc, expressando a quantidade de anticorpos presentes nos soros. 
4.b.2. REATIVIDADE DE ANTICORPOS DO ISÓTIPO IgG PRESENTE NOS SOROS DE COELHOS IMUNIZADOS PELA VIA INTRANASAL COM DUAS DOSES DE WHOLE CELLS DE N. LACTAMICA E DUAS DOSES DE WHOLE CELLS DE $N$. MENINGITIDIS

A figura 7 mostra a reatividade dos anticorpos IgG no soro de coelho imunizado pela via intranasal. A quantidade de anticorpos do isotipo IgG aumentou quando analisados com whole cells de $N$. sicca e $N$. meningitidis isoladas de carreador (C). Podemos sugerir que após a imunização com whole cells de $N$. meningitis novos clones foram estimulados produzindo anticorpos para novos antígenos presentes nestas cepas. Não observamos no protocolo utilizado um aumento significativo do título de anticorpos IgG de reatividade cruzada isto é clones não tinham previamente sido estimulados após as duas primeiras doses. A resposta de anticorpos IgG para $N$. lactamica após duas doses diminuiu até a obtenção do soro, sugerindo assim a necessidade de mais doses. Podemos também sugerir que as células foram sensibilizadas com duas doses de NL e induziram anticorpos de reatividade cruzada. $\mathrm{O}$ esquema utilizado mostra a necessidade de mais doses de imunização com a mesma preparação antigênica quando utilizamos a via nasal. A análise do índice de incremento dos anticorpos lgG do coelho 2 imunizado com duas doses de NL e duas doses de $N$. meningitidis não apresentou uma diferença significativa entre as cepas analisadas. Entretanto, podemos observar um aumento de anticorpos IgG que reagiram com a cepa de N. meningitidis . 

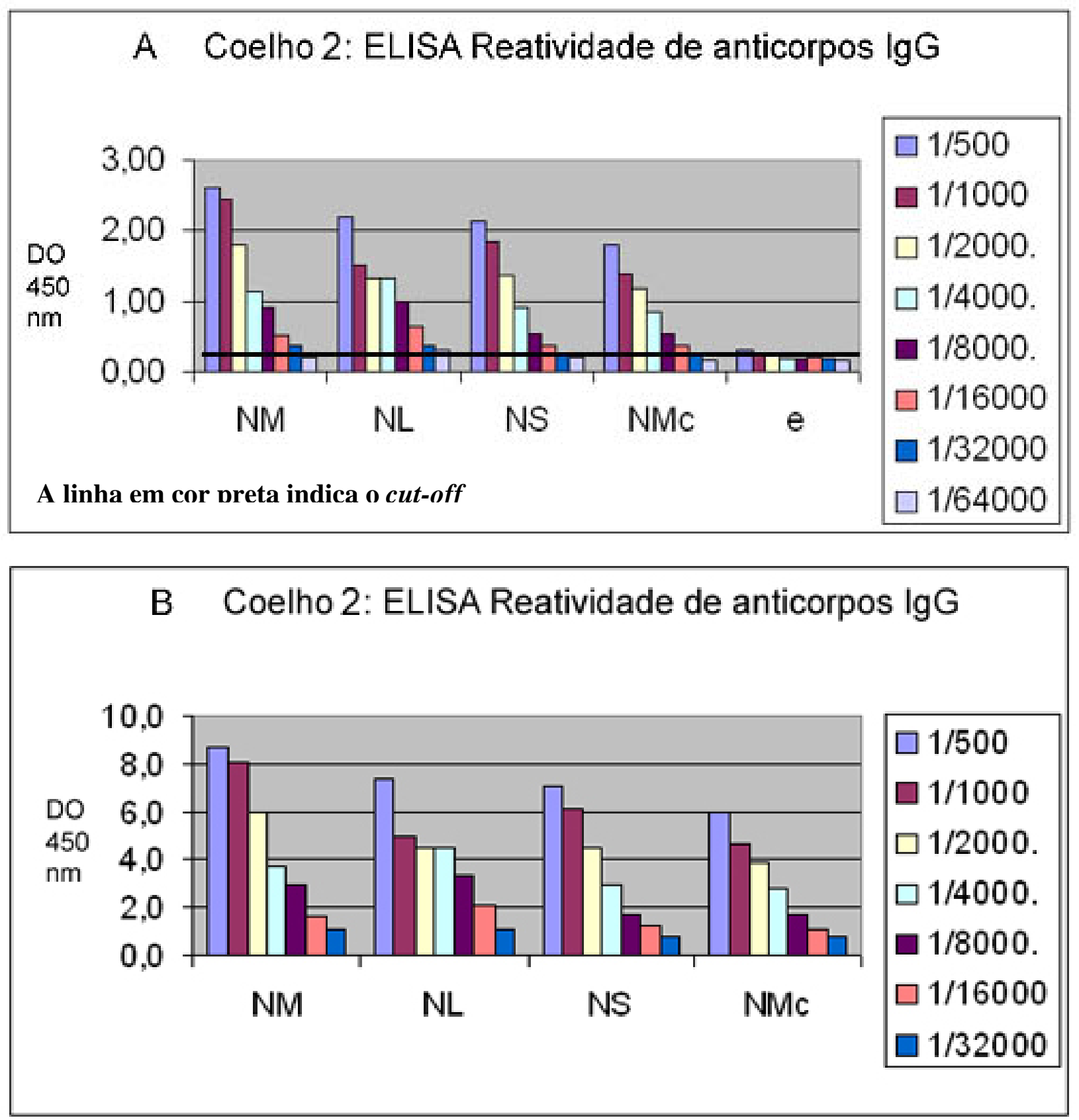

Figura 7 - (A) Estudo da produção de anticorpos lgG presentes no soro de coelhos imunizados com duas doses de $N$. lactamica e duas doses de $N$. lactamica pela via intranasal. Reatividade com N. meningitidis e cepas do gênero Neisseria. Reatividade com as cepas (NM), (NL), (NS) e (NMc).

(B) Resultados da razão DO/média da recíproca dos títulos de anticorpos IgG contra antígenos de NM, NL, NS e MMc, expressando a quantidade de anticorpos presentes nos soros. 
4.b-3. REATIVIDADE DE ANTICORPOS DO ISÓTIPO IgG PRESENTE NO SORO DE COELHO IMUNIZADO PELA VIA INTRANASAL COM QUATRO DOSES DE WHOLE CELLS DE N. SICCA

A figura 8 apresenta a reatividade do anticorpo IgG no soro de coelho imunizado pela via intranasal, com quatro doses de whole cells de $N$. sicca, o qual apresentou uma reatividade preferencial de anticorpos IgG para a cepa de NS utilizada (cepa homóloga). 


\section{A Coelho 3: ELISA Reatividade de anticorpos IgG}
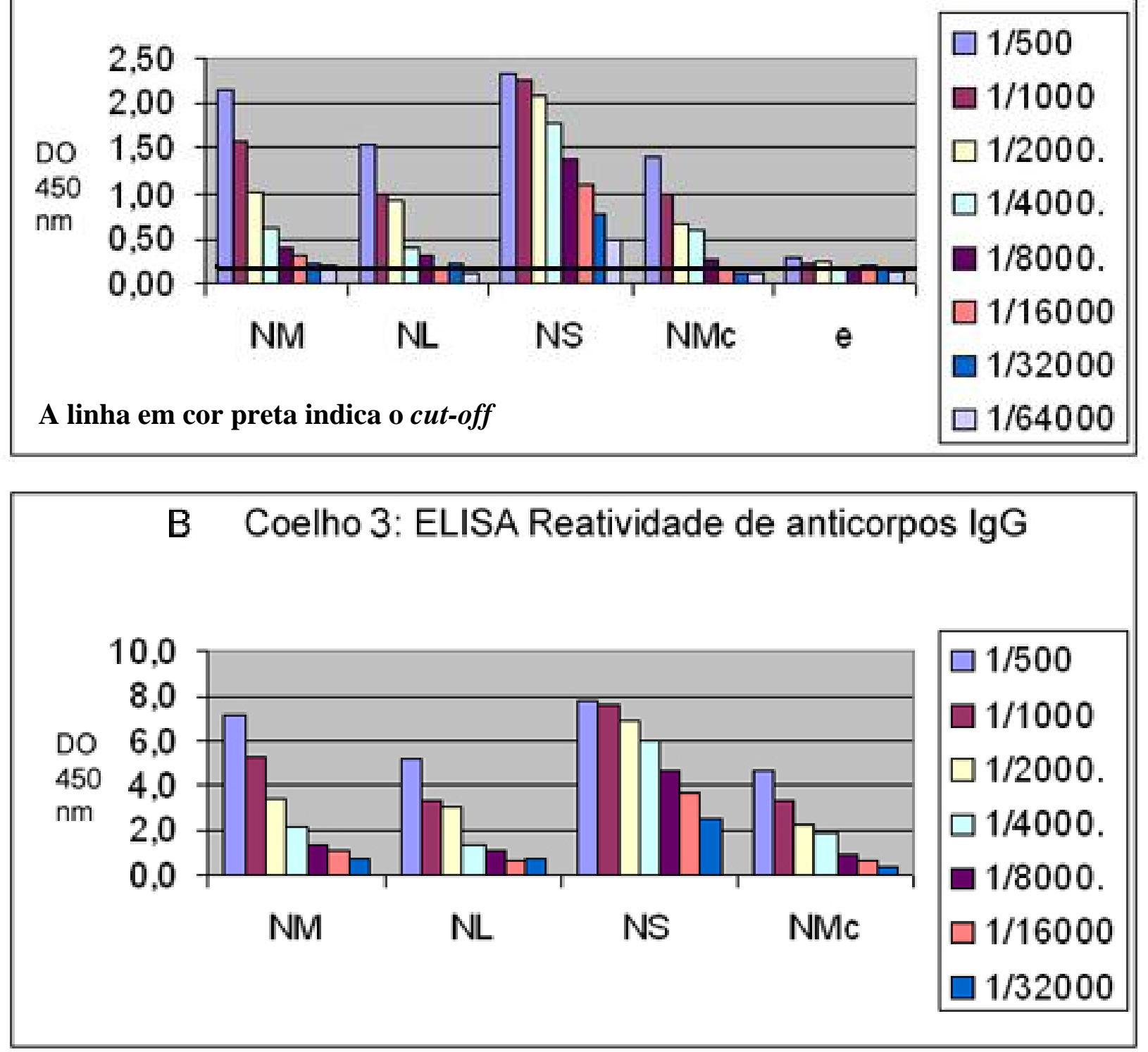

Figura 8 - (A) Estudo da produção de anticorpos IgG presentes no soro de coelhos imunizados com quatro doses de $N$. sicca pela via intranasal. Reatividade com $N$. meningitidis e cepas do gênero Neisseria. Reatividade com as cepas (NM), (NL), (NS) e (NMc).

(B) Resultados da razão DO/média da recíproca dos títulos de anticorpos IgG contra antígenos de NM, NL, NS e MMc, expressando a quantidade de anticorpos presentes nos soros. 
4.b.4. REATIVIDADE DE ANTICORPOS DO ISÓTIPO IgG PRESENTE NO SORO DE COELHO IMUNIZADO PELA VIA INTRANASAL COM DUAS DOSES DE WHOLE CELLS DE N. SICCA E DUAS DOSES DE WHOLE CELLS DE N. MENINGITIDIS

A figura 9 apresenta a reatividade do anticorpo IgG no soro de coelho imunizado pela via intranasal, com duas doses de whole cells de $N$. sicca e duas doses whole cells de $N$. meningitidis. Após a imunização com N. meningitidis podemos observar um aumento na quantidade de anticorpos IgG para $N$. lactamica, $N$. sicca e $N$. meningitidis sugerindo assim que whole cells de $N$. sicca foi capaz de sensibilizar e estimular clones produtores de anticorpos IgG de reatividade comum. A análise dos resultados da razão DO/média dos títulos de anticorpos IgG contra antígenos de NM, NL, NS e MMc demonstram a modificação do padrão de reatividade em relação aos soros normais dos coelhos. 

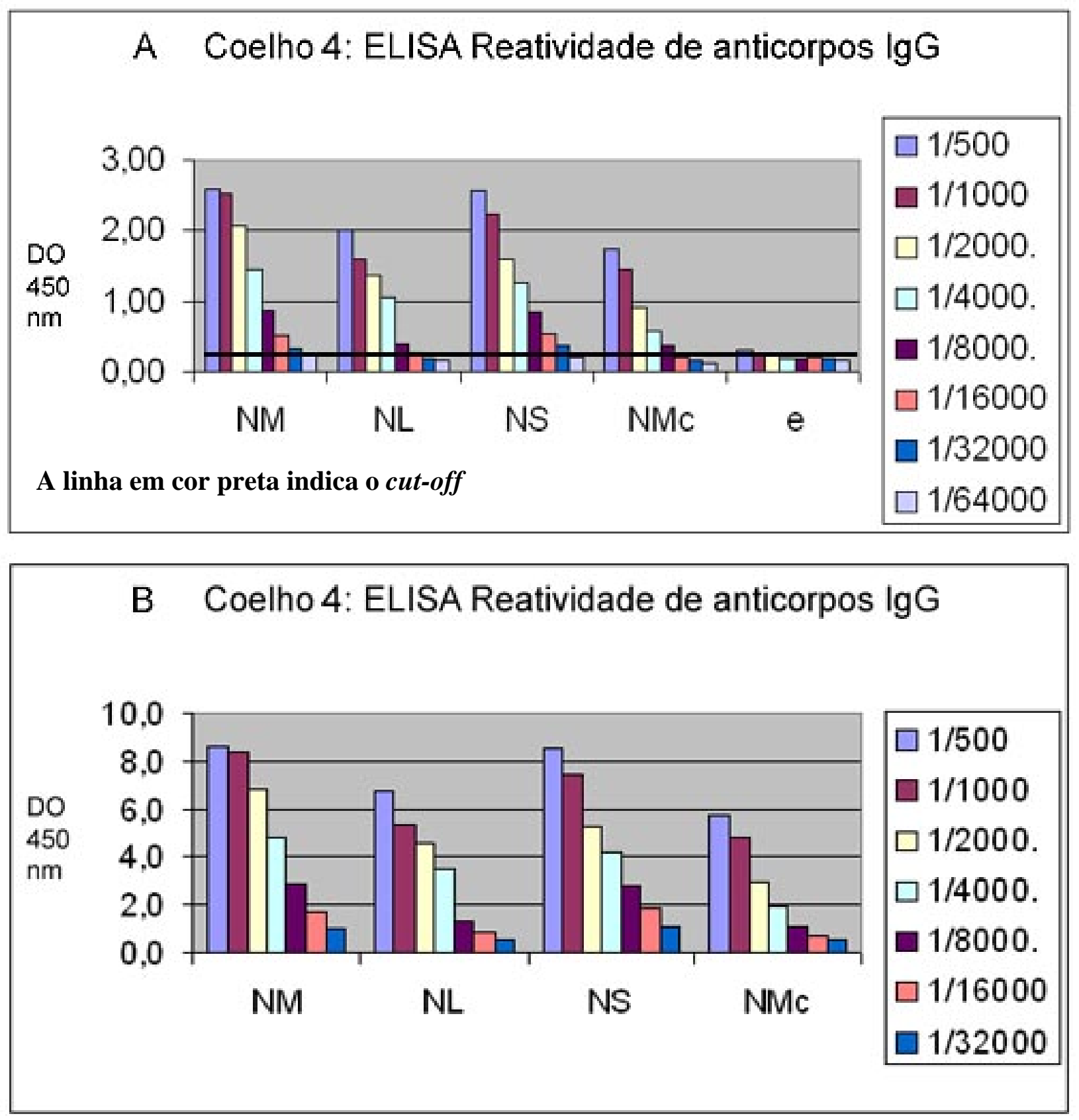

Figura 9 - (A) Estudo da produção de anticorpos IgG presentes no soro de coelhos imunizados com duas doses de $N$. sicca e duas doses de $N$. meningitidis $B$ pela via intranasal. Reatividade com $N$. meningitidis e cepas do gênero Neisseria. Reatividade com as cepas (NM), (NL), (NS) e (NMc).

(B) Resultados da razão DO/média da recíproca dos títulos de anticorpos IgG contra antígenos de NM, NL, NS e MMc, expressando a quantidade de anticorpos presentes nos soros. 
4.b-5. REATIVIDADE DE ANTICORPOS DO ISÓTIPO IgG PRESENTE NO SORO DE COELHO IMUNIZADO PELA VIA INTRANASAL COM QUATRO DOSES DE WHOLE CELLS DE N. MENINGITIDIS C.

A figura 10 apresenta a reatividade do anticorpo IgG no soro de coelho imunizado pela via intranasal, com quatro doses com whole cells de $N$. meningitidis $C$.

Por meio de ELISA interessantemente, observamos também uma reatividade preferencial para whole cells de $N$. meningitidis $c$, entretanto uma maior quantidade de anticorpos do isótipo IgG foram produzidos para N. lactamica, N. meningitidis sugerindo assim um maior número de antígenos comuns. A análise dos resultados da razão DO/média dos títulos de anticorpos IgG contra antígenos de NM,NL,NS e MMc confirma a reatividade preferencial para NMc utilizada. A cepa de NMc é do sorogrupo A: P1.9, entretanto apresenta muitos antígenos comuns independente do sorogrupo. Anticorpos IgG apresentaram uma boa reatividade para antígenos de NL. A análise dos resultados da razão DO media confirmam os resultados. 


\section{A Coelho 5: ELISA Reatividade de anticorpos IgG}
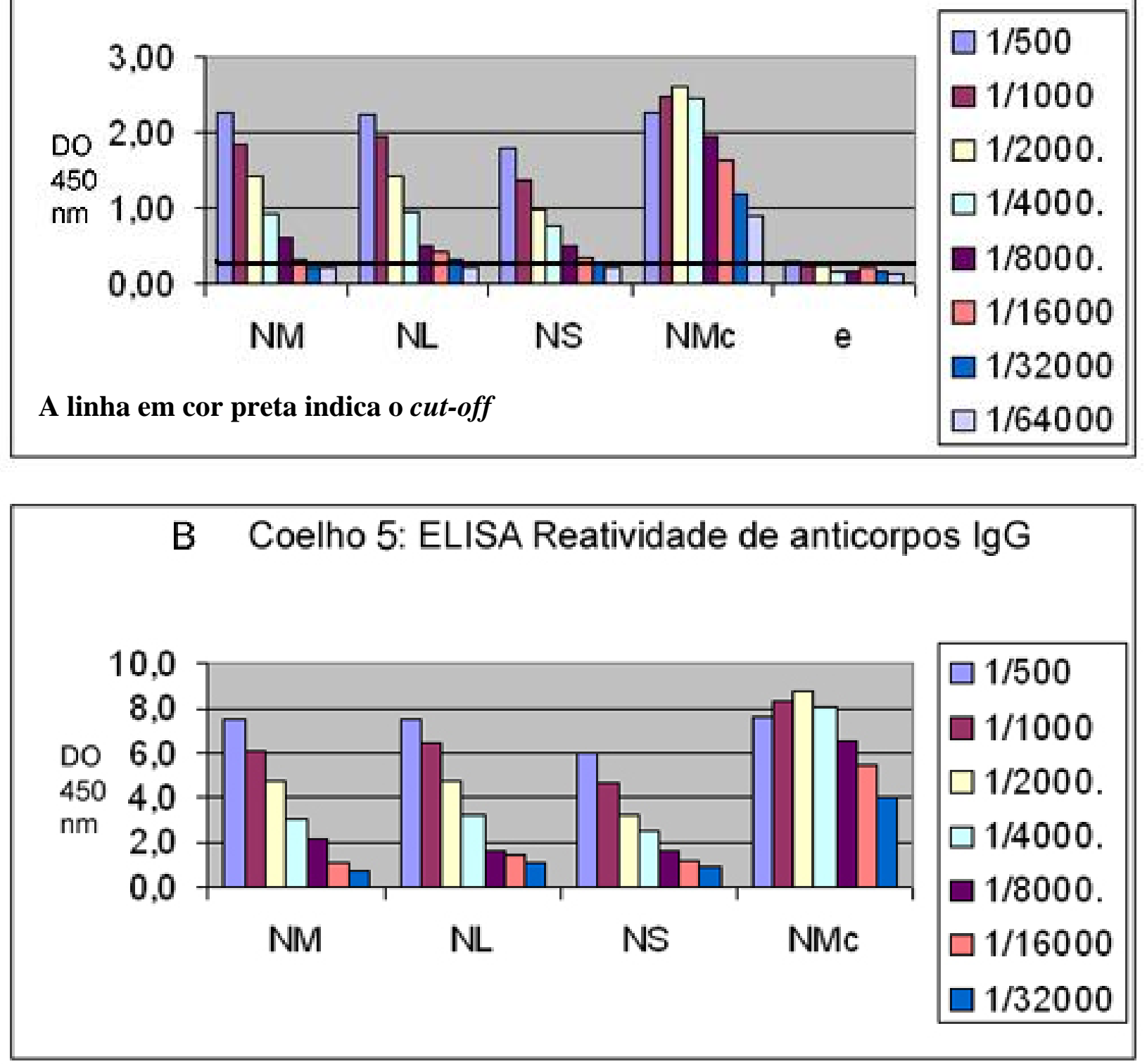

Figura 10 - (A) Estudo da produção de anticorpos IgG presentes no soro de coelhos imunizados com quatro doses de $N$. meningitidis $c$ (isolada de carreador) pela via intranasal. Reatividade com $N$. meningitidis e cepas do gênero Neisseria. Reatividade com as cepas (NM), (NL), (NS) e (NMc).

(B) Resultados da razão DO/média da recíproca dos títulos de anticorpos IgG contra antígenos de NM, NL, NS e MMc, expressando a quantidade de anticorpos presentes nos soros. 
4.b.6. REATIVIDADE DE ANTICORPOS DO ISÓTIPO IgG PRESENTE NO SORO DE COELHO IMUNIZADO PELA VIA INTRANASAL COM DUAS DOSES DE WHOLE CELLS DE N. MENINGITIDIS C E DUAS DOSES DE WHOLE CELLS DE $N$. MENINGITIDIS.

A figura 11 apresenta a reatividade do anticorpo IgG no soro de coelho imunizado pela via intranasal, com duas doses de whole cells de $N$. meningitidis $c$ e duas doses de whole cells de N. meningitidis .

A análise destes resultados mostrou um aumento significativo de anticorpos para whole cells de $N$. meningitidis, mostrando a presença de antígenos de reatividade cruzada. Os títulos de anticorpos para as outras bactérias também permaneceram elevados após as duas doses com whole cells de N. meningitidis. 

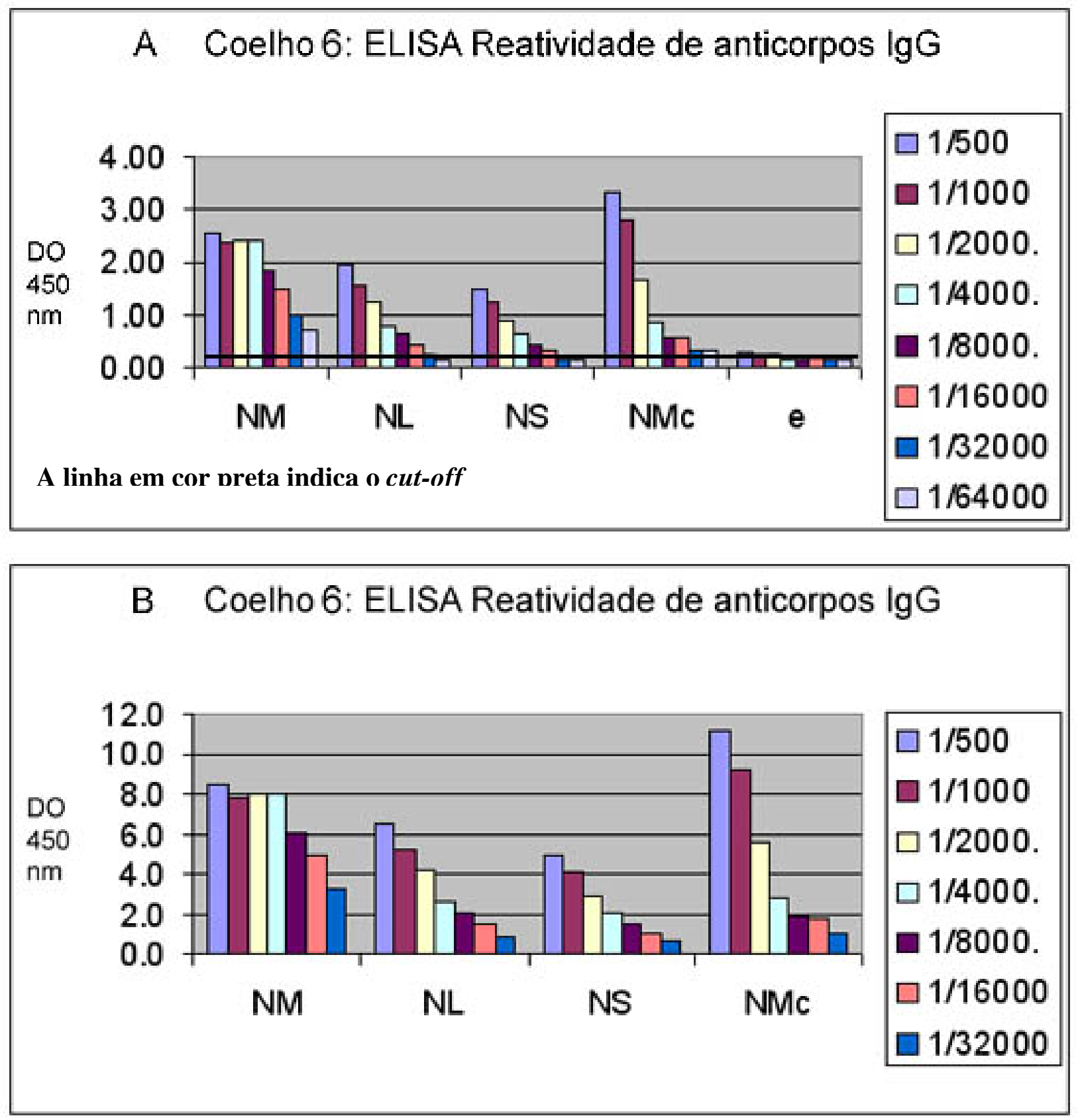

Figura 11 - (A) Estudo da produção de anticorpos IgG presentes no soro de coelho imunizado com duas doses de $N$. meningitidis $c$ (isolada de carreador) e duas doses de N.meningitidis pela via intranasal. Reatividade com $N$. meningitidis e cepas do gênero Neisseria. Reatividade com as cepas (NM), (NL), (NS) e (NMc).

(B) Resultados da razão DO/média da recíproca dos títulos de anticorpos IgG contra antígenos de NM, NL, NS e MMc, expressando a quantidade de anticorpos presentes nos soros. 
4.b.7. REATIVIDADE DE ANTICORPOS DO ISÓTIPO IgG PRESENTE NO SORO DE COELHO IMUNIZADO PELA VIA INTRANASAL COM QUATRO DOSES DE WHOLE CELLS DE N. MENINGITIDIS

A figura 12 apresenta a reatividade do anticorpo IgG no soro de coelho imunizado pela via intranasal, com quatro doses de whole cells de $N$. meningitidis.

A análise destes resultados mostrou um aumento significativo de anticorpos IgG para whole cells de $N$. meningitidis cepa homóloga utilizada também pudemos observar um aumento significativo no título de anticorpos para as outras bactérias do gênero Neisseria mostrando assim a presença de antígenos comuns nestas bactérias analisadas. 


\section{A Coelho 7: ELISA Reatividade de anticorpos IgG}
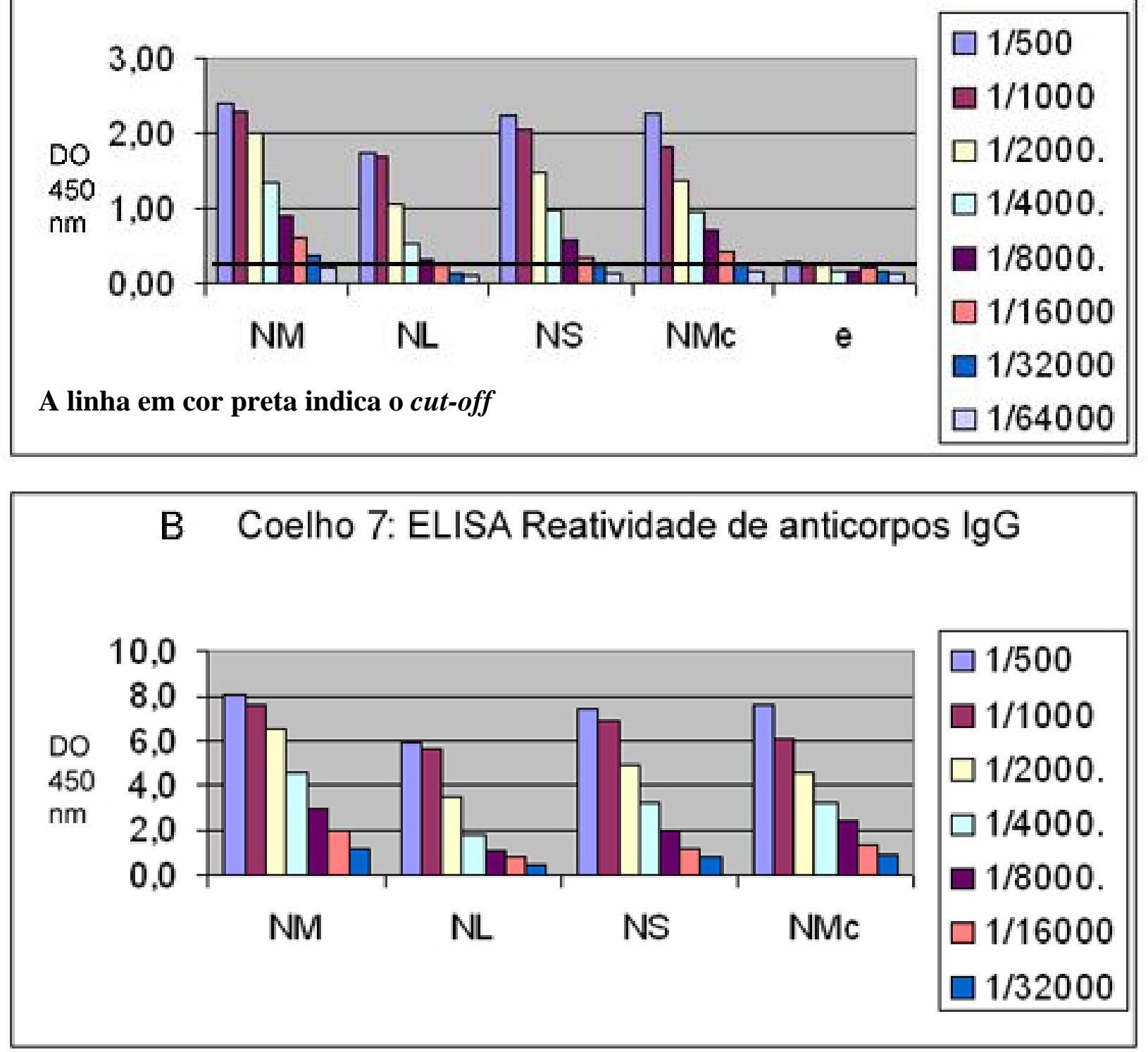

Figura 12 - (A) Estudo da produção de anticorpos IgG presentes no soro de coelhos imunizados com quatro doses de $N$. meningitidis B pela via intranasal. Reatividade com $N$. meningitidis e cepas do gênero Neisseria. Reatividade com as cepas (NM), (NL), (NS) e (NMc)

(B) Resultados da razão DO/média da recíproca dos títulos de anticorpos IgG contra antígenos de NM, NL, NS e MMc, expressando a quantidade de anticorpos presentes nos soros. 
4.b.8. REATIVIDADE DE ANTICORPOS DO ISÓTIPO IgG PRESENTE NO SORO DE COELHO IMUNIZADO PELA VIA INTRANASAL COM DUAS DOSES DE WHOLE CELLS DE N. MENINGITIS E DUAS DOSES DE WHOLE CELLS DE N.LACTAMICA.

A figura 13 apresenta a reatividade do anticorpo IgG no soro de coelho imunizado pela via intranasal, com duas doses de whole cells de $N$. meningitis e duas doses de whole cells de N. lactamica .

A análise destes resultados mostrou que não houve uma diferença significativa no título de anticorpos quando comparado com o animal imunizado com 4 doses de $N$ meningitidis sugerindo que não houve a ativação de novos clones produtores de anticorpos IgG, mostrando assim uma grande homologia entre NL e NM . 

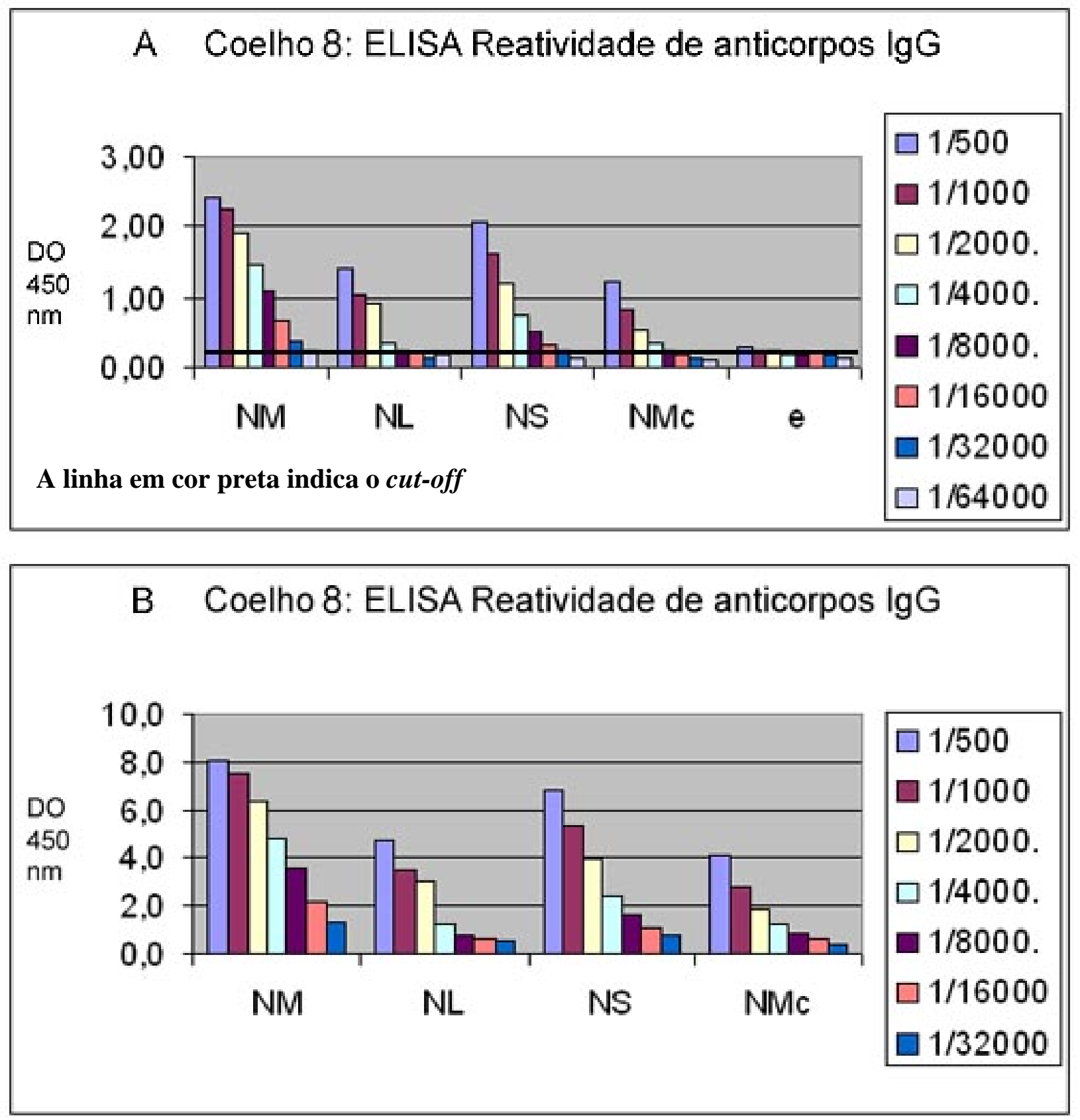

Figura 13 - (A) Estudo da produção de anticorpos IgG presentes no soro de coelhos imunizados com duas doses de $N$. meningitis e duas doses de $N$. lactamica pela via intranasal. Reatividade com N. meningitidis e cepas do gênero Neisseria. Reatividade com as cepas (NM), (NL), (NS) e (NMc).

(B) Resultados da razão $\mathrm{DO}$ /média da recíproca dos títulos de anticorpos IgG contra antígenos de NM, NL, NS e MMc, expressando a quantidade de anticorpos presentes nos soros. 
Tabela 5: Índice de aumento da reatividade apresentado por anticorpos dos isótipos IgG por meio de ELISA presentes em coelhos imunizados com whole cells de $N$. meningitidis e whole cells de bactérias do gênero Neisseria pela via intranasal

\begin{tabular}{lcccc}
\hline & NM & NL & NS & NMc \\
\hline Coelho 1 & 5,5 & 6,9 & 4,5 & 4,9 \\
Coelho 2 & 4,6 & 4,0 & 3,5 & 3,0 \\
Coelho 3 & 3,0 & 2,2 & 5,6 & 2,0 \\
Coelho 4 & 4,9 & 3,3 & 4,5 & 2,6 \\
Coelho 5 & 3,6 & 3,7 & 2,9 & 7,0 \\
Coelho 6 & 6,7 & 3,3 & 2,5 & 7,7 \\
Coelho 7 & 4,7 & 2,8 & 3,8 & 5,2 \\
Coelho 8 & 4,8 & 3,7 & 3,2 & 4,2 \\
\hline
\end{tabular}

NM (N. meningitis B); NL (N. lactamica); NS (N. sicca); NMc (N. meningitidis isolada de carreador). $\mathrm{O}$ índice de aumento da reatividade foi determinado através da comparação da D.O. média apresentada no soro dos coelhos imunizados em relação ao soro normal dos coelhos obtidos antes da imunização.

\section{4c. Determinação do índice de avidez dos anticorpos IgG nos soros dos coelhos} imunizados pela via intranasal.

A determinação dos títulos de anticorpos por meio de ELISA não oferece nenhuma informação sobre a funcionalidade dos anticorpos presentes no soro, induzidos por diferentes vias de imunização para diferentes preparações antigênicas. No entanto, em um ensaio de ELISA modificado utilizando substâncias caotrópicas, pode determinar a eluição de anticorpos IgG com ligações fracas, enquanto que as ligações de alta força foram mantidas, ou seja, anticorpos de baixa ou alta avidez. 
Tabela 6: Índice de avidez de anticorpos dos isótipos IgG no soro de coelhos imunizados pela vias intranasal para N. meningitidis.

\begin{tabular}{|c|c|c|}
\hline Coelhos & $\begin{array}{c}\text { Isótipos de } \\
\text { imunoglobulinas }\end{array}$ & $\begin{array}{l}\text { Avidez dos anticorpos IgG } \\
\text { em coelhos imunizados }\end{array}$ \\
\hline 1 & IgG & 0,37 \\
\hline 2 & $\operatorname{IgG}$ & 1,00 \\
\hline 3 & $\operatorname{IgG}$ & 0,93 \\
\hline 4 & $\operatorname{IgG}$ & 0,76 \\
\hline 5 & $\operatorname{IgG}$ & 1,00 \\
\hline 6 & $\lg G$ & 0,54 \\
\hline 7 & $\lg G$ & 0,75 \\
\hline 8 & $\operatorname{IgG}$ & 0,88 \\
\hline
\end{tabular}

\section{4d. IMMUNOBLOTTING}

Por meio de Immunoblotting, pudemos observar a especificidade dos anticorpos IgG presentes nos soros de coelhos imunizados pela via nasal para whole cells de cepas de $N$. meningitidis e bactérias do gênero Neisseria. Os soros dos coelhos foram analisados individualmente. 
Também por Immunoblot utilizando o anticorpo monoclonal 8C7Br1 (De Gaspari, 2000b) analisamos a reatividade para diferentes cepas descritas na tabela 2.

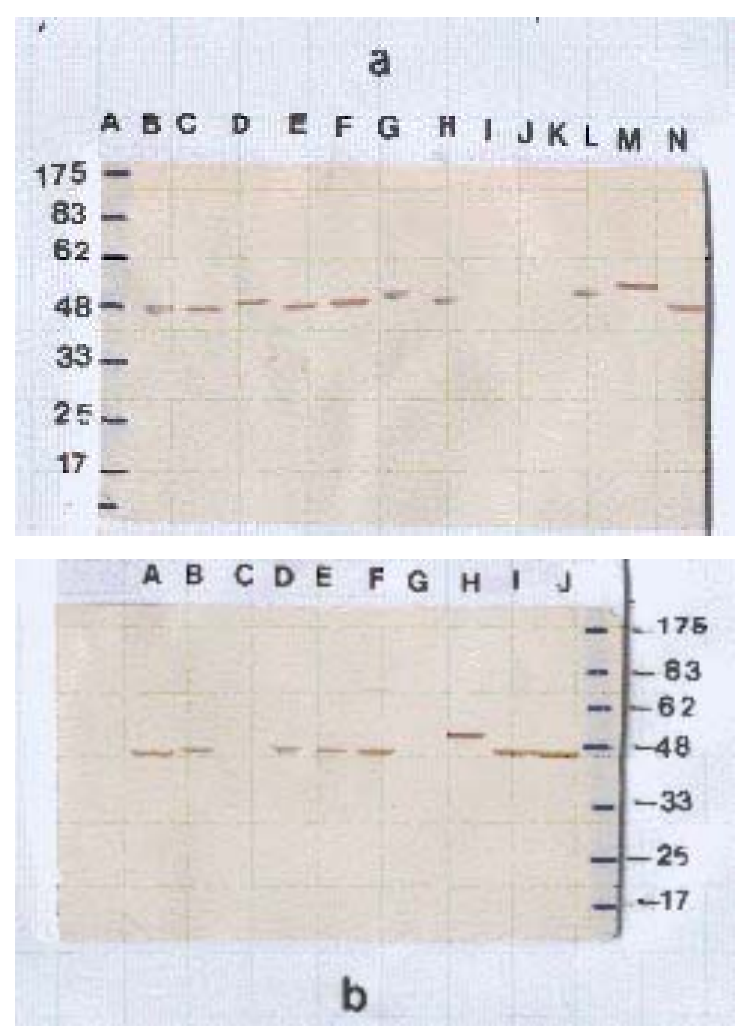

Fig. 14 - Reatividade do anticorpo monoclonal 8C7Br1 com cepas de $N$. meningidis e bactérias do gênero Neisseria.

\section{Blot A.}
A) $602 / 91(\mathrm{NL})$;
B) 362 / 92 (NL);
C) $124 / 94(\mathrm{NL})$;
D) 1024 / $94(\mathrm{NL})$;
E) $124 / 96(\mathrm{NL})$;
G) $831 / 98(\mathrm{NL})$;
H) $844 / 95(\mathrm{NL})$;
F) $924 / 93(\mathrm{NL})$;
J) 852 / $93(\mathrm{NL})^{*}$;
K) 952 / $93(\mathrm{NL})^{*}$;
I) $1398 / 00(\mathrm{NL})^{*}$;
M) 368 / 88 (NM);
N) 369 / 88 (NM).
L) 360 / 88 (NM);

Blot B.
A) 799 / 98 (NL);
D) 699 / 99 (NE);
B) $44 / 00(\mathrm{Nm})$;
C) 456 / 99 (NS);
G) $148 / 00$ (NSP);
E) $123 / 00$ (NF);
F) $613 / 98$ (NSP);
J) $360 / 88$ (NM).
H) 20 / 00 (NSP);
I) 44 / 89 (NM);

${ }^{*}$ Cepas de NL que não apresentaram reatividade cruzada com o Mab 8C7Br1 
$\mathrm{Na}$ figura 14 podemos analisar a reatividade do anticorpo monoclonal 8C7Br1 para o antígeno de 50-65 kDa nas cepas de N. meningitidis, N. lactamica, N. mucosa, N. flava, N. subflava perflava utilizadas em nossos estudos.

Para realização deste estudo, utilizamos suspensões de células integras das bactérias. Com as cepas de NL utilizada neste estudo observamos uma reatividade do anticorpo monoclonal $8 \mathrm{C} 7 \mathrm{Br} 1$ com $70 \%$ das cepas de NL utilizadas.

Por meio de Immunoblot pudemos analisar a especificidade dos anticorpos dos isótipos IgG produzidos em coelho imunizado pela via intranasal. Neste estudo foram utilizados 8 coelhos que foram imunizados com whole cells de $N$. meningitidis ou whole cells de bactérias do gênero Neisseria pela via intranasal. 


\section{4.d.1. REATIVIDADE POR MEIO DE IMMUNOBLOT DE ANTICORPOS DO ISÓTIPO IgG PRESENTE NO SORO DE COELHO IMUNIZADO PELA VIA INTRANASAL COM QUATRO DOSES DE N. LACTAMICA}

Os anticorpos IgG presente no soro apresentou uma reatividade para a cepa homóloga para os peptídeos de 10-120 kDa (e).

Na figura 15 (A) em b, c e g pudemos observar claramente um número maior de peptídeos sendo reconhecidos nas cepas de $N$. meningitidis utilizadas. A reatividade para NOMV da cepa de $N$. meningidis se restringiu ao reconhecimento dós antígenos de 80,50 e $37 \mathrm{kDa}$.

Na tabela 7 podemos observar a reatividade para vários antígenos comuns, entretanto o antígeno de $110 \mathrm{kDa}$ foi reconhecido apenas na cepa de $\mathrm{N}$. meningitidis isolada de carreador.

Os peptídeos de 28, 50, e 70 kDa foram reconhecidos por anticorpos IgG.

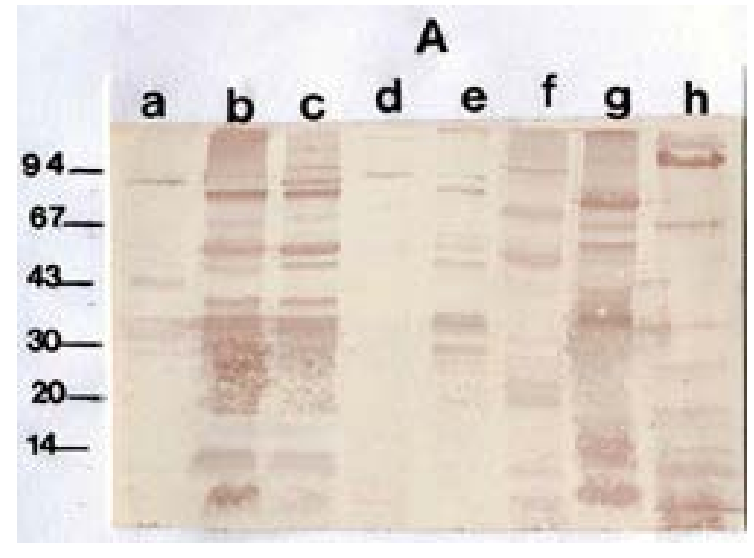

Fig.15- Immunoblot de suspensão de células bacterianas integras (whole cells) de $N$. meningitidis e bactérias do gênero Neisseria e NOMV da cepa de N. menigitidis.

Reatividade de anticorpos IgG de coelhos imunizados com quatro doses de NL pela via i.n.
a) NOMV da cepa 44 / 89 NM;
b) whole cells da cepa 44 / $89 \mathrm{NM}$;
c) $360 / 88 \mathrm{NM}$;
d) $1024 / 94 \mathrm{NL}$;
e) 602 / 91NL;
f) $799 / 98 \mathrm{NL}$;
g) NSP10 NS;
h) $391 \mathrm{NMc}$. 
4.d.2. REATIVIDADE POR MEIO DE IMMUNOBLOT DE ANTICORPOS DO ISÓTIPO IgG PRESENTE NO SORO DE COELHO IMUNIZADO PELA VIA INTRANASAL COM DUAS DOSES DE N. LACTAMICA E DUAS DOSES DE N. MENINGITIDIS

$\mathrm{Na}$ figura 16 (B), quando utilizamos este esquema podemos observar uma restrição do reconhecimento antigênico para os peptídeos de $80 \mathrm{kDa}$ em N. meningitidis e $60 \mathrm{kDa}$ em uma das cepas de $N$. lactamica utilizada (e). Houve uma reatividade preferencial para antígenos presentes em $N$. meningitis. Não observamos reatividade para antígenos presentes nas cepas de $N$. sicca e na cepa isolada de $N$. meningitidis obtida de carreador.

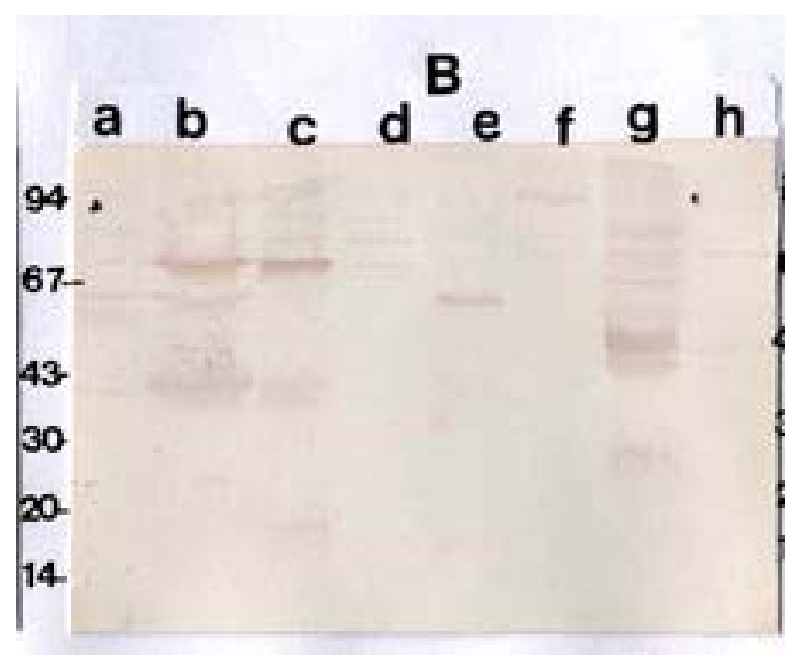

Fig. 16 Immunoblot de suspensão de células bacterianas integras (whole cells) de $N$. meningitidis e bactérias do gênero Neisseria e NOMV da cepa de $N$. menigitidis.

Reatividade de anticorpos IgG de coelhos imunizados com duas doses de NL e duas doses de NM pela via i.n.
a) NOMV da cepa 44 / 89 NM;
b) whole cells da cepa 44 / $89 \mathrm{NM}$;
c) $360 / 88 \mathrm{NM}$;
d) $1024 / 94 \mathrm{NL}$;
e) 602 / 91NL;
f) $799 / 98 \mathrm{NL}$;
g) NSP10 NS;
h) $391 \mathrm{NMc}$. 


\section{4.d.3. REATIVIDADE POR MEIO DE IMMUNOBLOT DE ANTICORPOS DO ISÓTIPO IgG PRESENTE NO SORO DE COELHO IMUNIZADO PELA VIA INTRANASAL COM QUATRO DOSES DE N. SICCA.}

A figura 17 (C) apresenta resultados da especificidade de anticorpos IgG obtido de coelhos para cepa homóloga de $N$. sicca (f) e com as cepas heterólogas. A especificidade dos anticorpos IgG foi para whole cells. Pudemos observar uma reatividade preferencial para o peptídeo de $80 \mathrm{kDa}$ nas cepas utilizadas. Não observamos reatividade para o peptídeo de $80 \mathrm{kDa}$ na cepa de $N$. meningitidis obtida de carreador. Outro ponto interessante é que um número menor de peptídeos foi reconhecido na cepa de $N$. meningitidis (NOMV ou whole cells (b, c e g). Uma reatividade preferencial foi observado para o peptídeo de $60 \mathrm{kDa}$ de $N$ sicca .

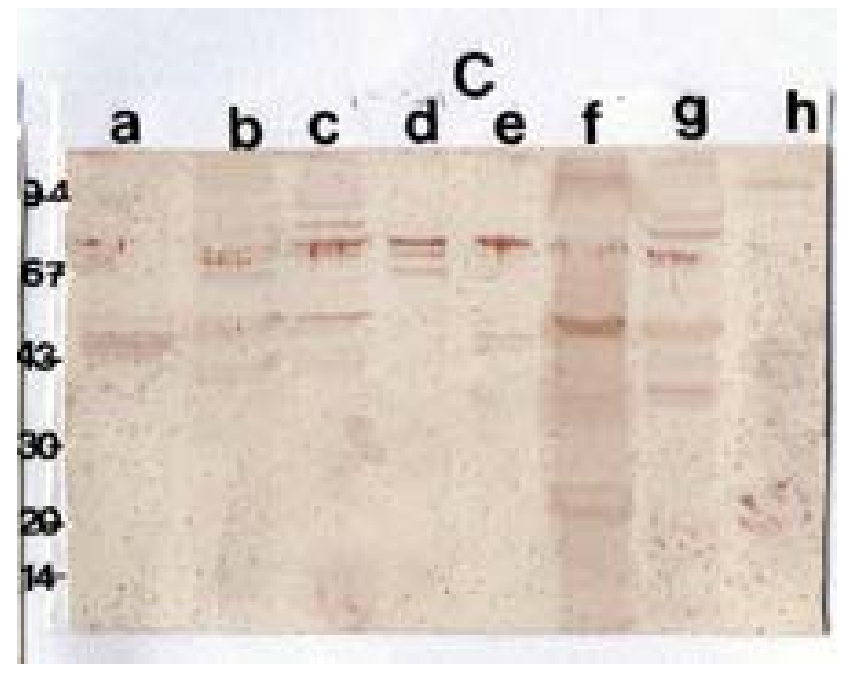

Fig.17 Immunoblot de suspensão de células bacterianas integras (whole cells) de N. meningitidis e bactérias do gênero Neisseria e NOMV da cepa de N. menigitidis.

Reatividade de anticorpos IgG de coelhos imunizados com quatro doses de NS pela via i.n.
a) NOMV da cepa 44 / 89 NM;
b) whole cells da cepa 44 / $89 \mathrm{NM}$;
c) 360 / 88NM;
d) $1024 / 94 \mathrm{NL}$;
e) 602 / 91NL;
f) 799 / $98 \mathrm{NL}$;
g) NSP10 NS;
h) $391 \mathrm{NMc}$. 


\section{4.d.4. REATIVIDADE POR MEIO DE IMMUNOBLOT DE ANTICORPOS DO ISÓTIPO IgG PRESENTE NO SORO DE COELHO IMUNIZADO PELA VIA INTRANASAL COM DUAS DOSES DE N. SICCA E DUAS DOSES DE N. MENINGITIDIS .}

A figura 18 (D) apresentou um padrão de reconhecimento de antígenos semelhante com o blot (B) anteriormente analisado. Mostrando claramente a necessidade de um número maior de doses. Provavelmente o reconhecimento destes antígenos é devido a imunização produzida com antígenos de $N$. meningitidis ou de reatividade cruzada $\operatorname{com} N$. sicca.

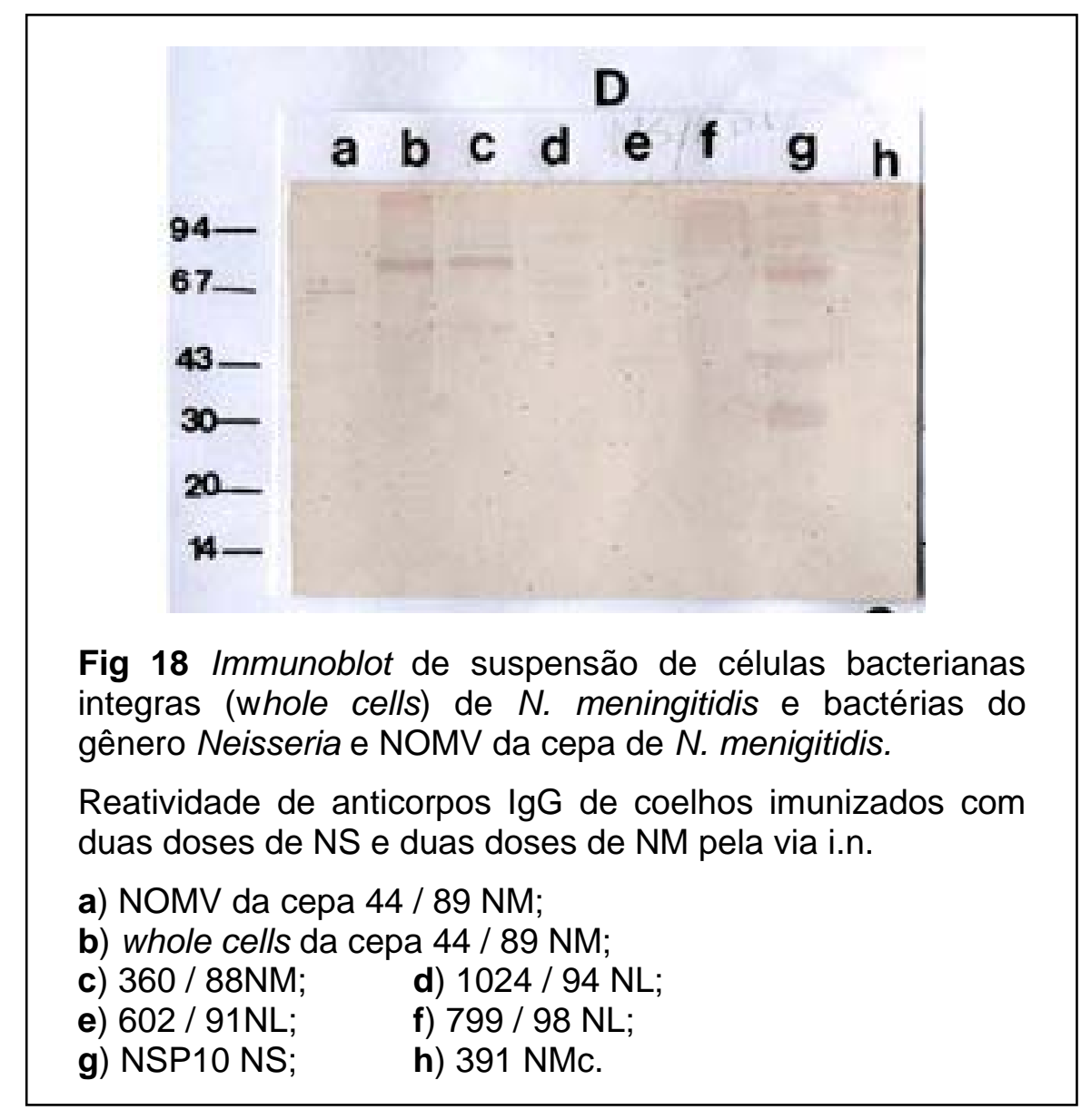




\section{4.d.5. REATIVIDADE POR MEIO DE IMMUNOBLOT DE ANTICORPOS DO ISÓTIPO IgG PRESENTE NO SORO DE COELHO IMUNIZADO PELA VIA INTRANASAL COM QUATRO DOSES DE N. MENINGITIDIS C}

$\mathrm{Na}$ figura 19 (E), quando utilizamos quatro doses de whole cells de $N$. meningitidis isolada de carreador, interessantemente observamos uma reatividade preferencial para o peptídeo de $80 \mathrm{kDa}$ para as cepas de $N$. meningitidis, $N$. lactamica e $N$. sicca. Uma reatividade homóloga (h) os anticorpos IgG reconheceram antígenos de 60,70 e de $130 \mathrm{kDa}$.

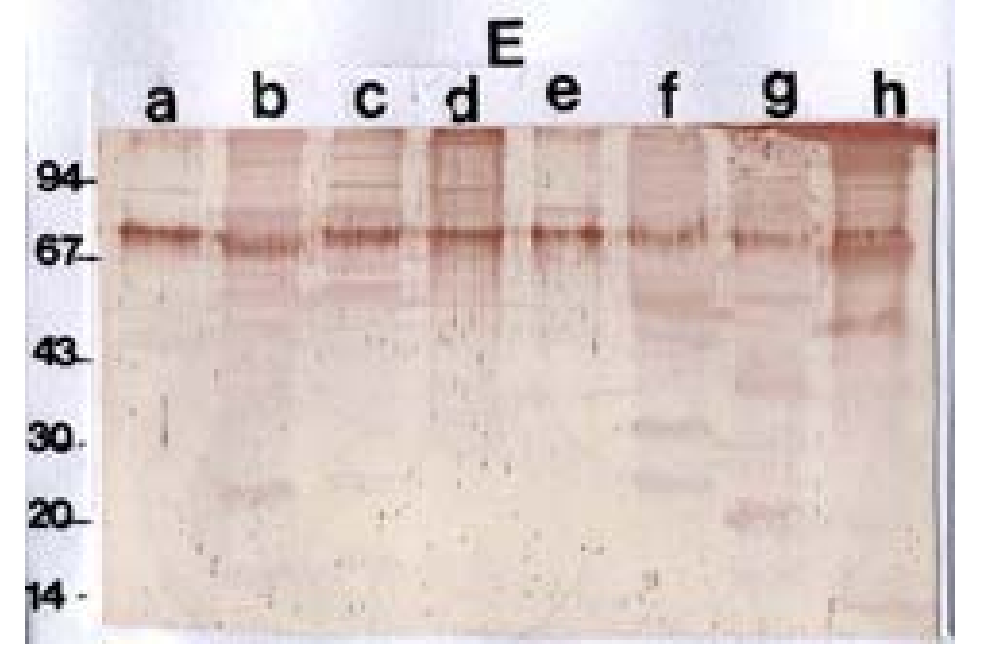

Fig 19- Immunoblot de suspensão de células bacterianas integras (whole cells) de N. meningitidis e bactérias do gênero Neisseria e NOMV da cepa de $N$. menigitidis.

Reatividade de anticorpos IgG de coelhos imunizados com quatro doses de NMc pela via i.n.
a) NOMV da cepa 44 / 89 NM;
b) whole cells da cepa 44 / $89 \mathrm{NM}$;
c) $360 / 88 \mathrm{NM}$;
d) 1024 / $94 \mathrm{NL}$;
e) $602 / 91 \mathrm{NL}$;
f) 799 / $98 \mathrm{NL}$;
g) NSP10 NS;
h) $391 \mathrm{NMc}$. 
4.d.6. REATIVIDADE POR MEIO DE IMMUNOBLOT DE ANTICORPOS DO ISÓTIPO IgG PRESENTE NO SORO DE COELHO IMUNIZADO PELA VIA INTRANASAL COM DUAS DOSES DE N. MENINGITIDIS C E DUAS DOSES DE N. MENINGITIDIS

$\mathrm{Na}$ figura 20 (F) com o esquema utilizado observamos uma restrição no reconhecimento de antígenos direcionado principalmente para a cepa homóloga (h) antígenos de alto peso molecular de N. lactamica (d).

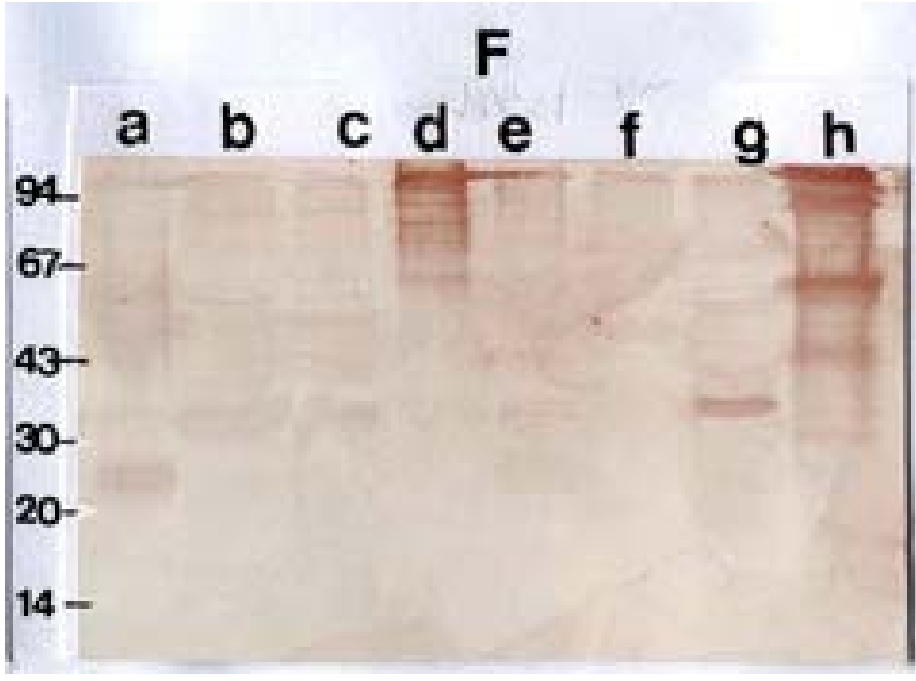

Fig. 20- Immunoblot de suspensão de células bacterianas integras (whole cells) de N. meningitidis e bactérias do gênero Neisseria e NOMV da cepa de $N$. menigitidis.

Reatividade de anticorpos IgG de coelhos imunizados com duas doses de NMc e duas doses NM e duas doses de pela via i.n.
a) NOMV da cepa 44 / 89 NM;
b) whole cells da cepa 44 / $89 \mathrm{NM}$;
c) $360 / 88 \mathrm{NM}$;
d) 1024 / $94 \mathrm{NL}$;
e) 602 / 91NL;
f) $799 / 98 \mathrm{NL}$;
g) NSP10 NS;
h) $391 \mathrm{NMc}$. 


\section{4.d.7. REATIVIDADE POR MEIO DE IMMUNOBLOT DE ANTICORPOS DO ISÓTIPO IgG PRESENTE NO SORO DE COELHO IMUNIZADO PELA VIA INTRANASAL COM QUATRO DOSES DE N. MENINGITIDIS}

Na figura $21(G)$ podemos observar a reatividade de anticorpos IgG para as cepas de $N$. meningitidis. Os anticorpos também reconheceram antígenos presentes e de diferentes pesos moleculares nas cepas utilizadas. Os resultados mostraram vários antígenos de reatividade cruzada.

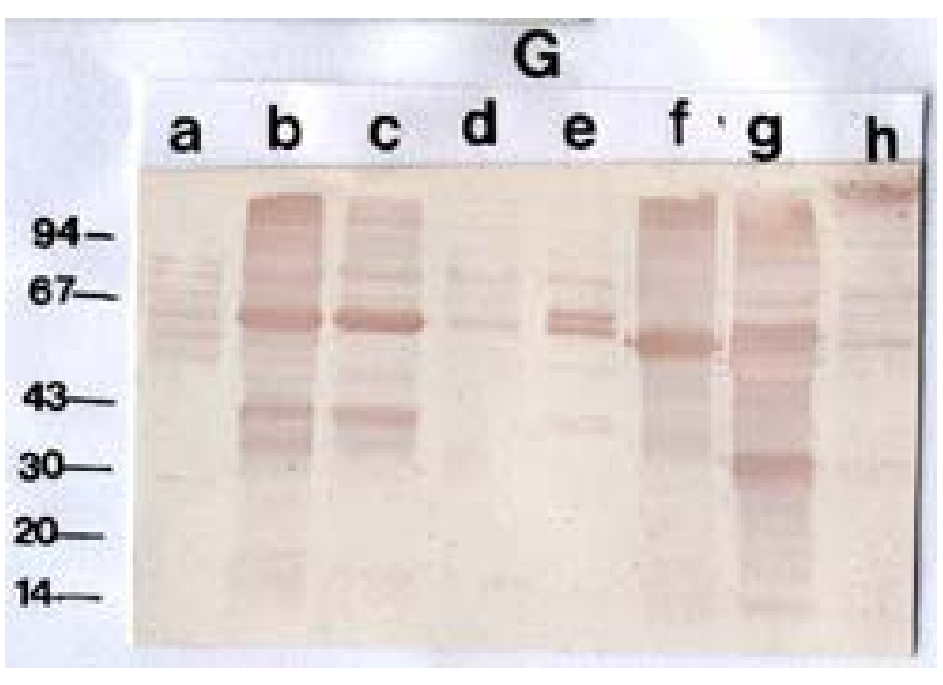

Fig. 21 Immunoblot de suspensão de células bacterianas integras (whole cells) de $N$. meningitidis e bactérias do gênero Neisseria e NOMV da cepa de $N$. menigitidis.

Reatividade de anticorpos IgG de coelhos imunizados com quatro doses de NM 44/89 pela via i.n.
a) NOMV da cepa 44 / 89 NM;
b) whole cells da cepa 44 / $89 \mathrm{NM}$;
c) $360 / 88 \mathrm{NM}$;
d) $1024 / 94 \mathrm{NL}$;
e) $602 / 91 \mathrm{NL}$;
f) $799 / 98 \mathrm{NL}$;
g) NSP10 NS;
h) $391 \mathrm{NMc}$. 
4.d.8. REATIVIDADE POR MEIO DE IMMUNOBLOT DE ANTICORPOS DO ISÓTIPO IgG PRESENTE NO SORO DE COELHO IMUNIZADO PELA VIA INTRANASAL COM DUAS DOSES DE N. MENINGITIDIS E DUAS DOSES DE N. LACTAMICA

$\mathrm{Na}$ figura $22 \mathrm{(H}$ ) antígenos comuns na faixa de (10-30) e (70-80) kDa continuaram sendo reconhecidos, entretanto o padrão de reconhecimento foi diferente dos observados no blot $(G)$. Sugerindo que a não modificação do padrão para reconhecimento destes antígenos esteja relacionada a antígenos comuns entre $N$. meningitidis e $N$. lactamica que talvez sejam importantes no mecanismo de proteção.

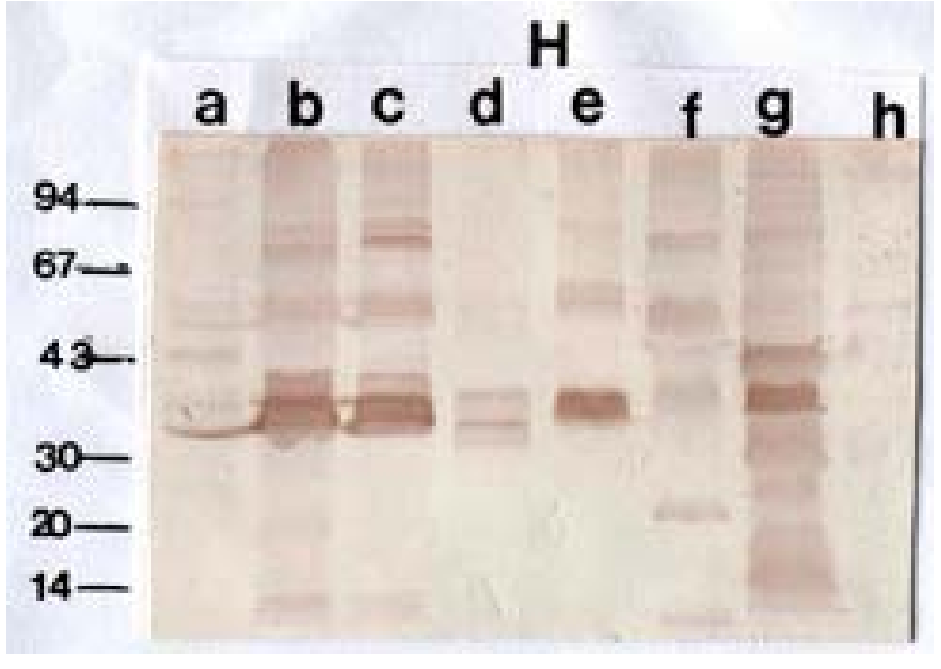

Fig. 22- Immunoblot de suspensão de células bacterianas integras (whole cells) de N. meningitidis e bactérias do gênero Neisseria e NOMV da cepa de $N$. menigitidis.

Reatividade de anticorpos IgG de coelhos imunizados com duas doses de NM e duas doses de NL pela via i.n.
a) NOMV da cepa 44 / 89 NM;
b) whole cells da cepa 44 / $89 \mathrm{NM}$;

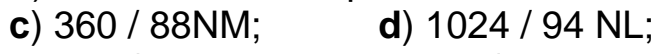
$\begin{array}{ll}\text { e) } 602 / 91 \mathrm{NL} ; & \text { f) } 799 / 98 \mathrm{NL} \text {; }\end{array}$

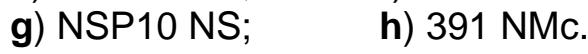


Tabela 7: Análise por meio de Immunoblot. Antígenos reconhecidos por anticorpos IgG produzidos após imunização nasal de coelhos com Whole cells de N. meningitidis e whole cells de cepas de Neisseria de outros gêneros .

(Immunoblot: Antígenos reconhecidos por anticorpos IgG de coelhos após imunização pela via nasal)

\begin{tabular}{|c|c|c|c|c|c|c|c|}
\hline & \multicolumn{7}{|c|}{ Peso Molecular } \\
\hline \multirow{9}{*}{ A } & & $5-10$ & $20-30$ & $40-50$ & $50-60$ & $70-80$ & $80-120$ \\
\hline & $\mathbf{a}$ & - & - & $\mathrm{X}$ & & $\mathrm{X}$ & $\mathrm{x}$ \\
\hline & b & $\underline{X}$ & $x$ & $x$ & & $x$ & $x$ \\
\hline & C & $X$ & $x$ & $x$ & & $x$ & $X$ \\
\hline & d & - & - & - & & $x$ & $\mathrm{X}$ \\
\hline & $\mathbf{e}$ & - & $\mathrm{X}$ & $\mathrm{x}$ & $x$ & $\mathrm{X}$ & $\mathrm{X}$ \\
\hline & $f$ & $X$ & - & $x$ & & $x$ & $X$ \\
\hline & g & $x$ & - & $x$ & & $x$ & $x$ \\
\hline & $\mathbf{h}$ & $\mathrm{X}$ & - & & & $X$ & $\mathrm{x}$ \\
\hline \multirow{9}{*}{ B } & & $5-10$ & $20-30$ & $40-50$ & $50-60$ & $70-80$ & $80-120$ \\
\hline & a & & & $x$ & & $x$ & \\
\hline & b & & $x$ & & & $x$ & \\
\hline & c & & $\mathrm{X}$ & & & $x$ & \\
\hline & d & & & & & & \\
\hline & $\mathbf{e}$ & & & & & & \\
\hline & $f$ & & & & & & \\
\hline & g & & & & & $x$ & $x$ \\
\hline & $\mathbf{h}$ & & & & & & \\
\hline \multirow{9}{*}{ C } & & $5-10$ & $20-30$ & $40-50$ & $50-60$ & $70-80$ & $80-120$ \\
\hline & $\mathbf{a}$ & & & $x$ & & & $\mathrm{X}$ \\
\hline & b & & & $x$ & & $x$ & \\
\hline & c & & & $x$ & & $\mathrm{X}$ & \\
\hline & d & & & & & $x$ & \\
\hline & $\mathbf{e}$ & & & & & $x$ & \\
\hline & $f$ & & $x$ & $x$ & & $x$ & \\
\hline & g & & & $x$ & & $\mathrm{X}$ & \\
\hline & h & & & & & & \\
\hline \multirow{9}{*}{ D } & & $5-10$ & $20-30$ & $40-50$ & $50-60$ & $70-80$ & $80-120$ \\
\hline & a & & & & & & \\
\hline & b & & & & $x$ & & \\
\hline & C & & & & $x$ & & \\
\hline & d & & & & $\mathrm{X}$ & & \\
\hline & e & & & & $X$ & & $X$ \\
\hline & f & & & & $X$ & & $\mathrm{X}$ \\
\hline & g & & & & $x$ & & $X$ \\
\hline & $\mathrm{h}$ & & & & & & $x$ \\
\hline
\end{tabular}




\begin{tabular}{|c|c|c|c|c|c|c|c|}
\hline \multirow{9}{*}{ E } & & $5-10$ & $20-30$ & $40-50$ & $50-60$ & $70-80$ & $80-120$ \\
\hline & $\mathbf{a}$ & & & & & $X$ & \\
\hline & b & & $X$ & $X$ & & $X$ & $X$ \\
\hline & c & & $x$ & $x$ & & $x$ & $x$ \\
\hline & d & & & & & $x$ & $X$ \\
\hline & e & & & & & $x$ & X \\
\hline & $f$ & & & $x$ & & $x$ & $x$ \\
\hline & $g$ & & & $x$ & & $x$ & $x$ \\
\hline & $\mathrm{h}$ & & & $X$ & & $x$ & $X$ \\
\hline \multirow{9}{*}{$F$} & & $5-10$ & $20-30$ & $40-50$ & $50-60$ & $70-80$ & $80-120$ \\
\hline & $\mathbf{a}$ & & & & & & \\
\hline & b & & & & & & \\
\hline & c & & & & & & \\
\hline & d & & & & & & $X$ \\
\hline & e & & & & & & \\
\hline & $f$ & & & & & & \\
\hline & g & & & & & & \\
\hline & $\mathrm{h}$ & & & & & & $x$ \\
\hline \multirow{9}{*}{ G } & & $5-10$ & $20-30$ & $40-50$ & $50-60$ & $70-80$ & $80-120$ \\
\hline & $\mathbf{a}$ & & & $x$ & $x$ & $x$ & \\
\hline & b & & $X$ & $x$ & $x$ & $x$ & $X$ \\
\hline & c & & $x$ & $x$ & $x$ & $x$ & $X$ \\
\hline & d & & & $x$ & $x$ & $x$ & \\
\hline & e & & $X$ & $x$ & $x$ & $x$ & \\
\hline & $f$ & & $x$ & $x$ & $x$ & $x$ & $x$ \\
\hline & g & & $x$ & $x$ & $x$ & $x$ & $X$ \\
\hline & $\mathrm{h}$ & & & $\mathrm{X}$ & $x$ & $x$ & $\mathrm{X}$ \\
\hline \multirow{9}{*}{ H } & & $5-10$ & $20-30$ & $40-50$ & $50-60$ & $70-80$ & $80-120$ \\
\hline & $a$ & & $x$ & & $x$ & & \\
\hline & b & & $X$ & & $x$ & $x$ & $x$ \\
\hline & c & & $x$ & & $x$ & $x$ & X \\
\hline & d & & $x$ & & & & \\
\hline & e & & $x$ & & $x$ & & \\
\hline & $f$ & & $x$ & & $x$ & $x$ & \\
\hline & g & & $x$ & & $x$ & $x$ & \\
\hline & $h$ & & $X$ & & $\mathrm{X}$ & & \\
\hline
\end{tabular}

Esquema de imunização utilizado:
A) quatro doses NL
B) duas doses NL e duas doses NM
C) quatro doses NS
D) duas doses NS e duas doses NM
E) quatro doses NMc
F) duas doses NMc e duas doses NM
$\mathrm{G})$ quatro doses $\mathrm{NM}$
H) duas doses NM e duas doses NL

NM ( $\mathrm{N}$ meningitis $\mathrm{B})$; NL ( $\mathrm{N}$ lactamica); NS ( $N$ sicca); NMc ( $N$ meningitidis isolada de carreador) 


\section{4e- ATIVIDADE BACTERICIDA}

\section{4.e.1- ATIVIDADE BACTERICIDA DE COELHOS IMUNIZADOS PELA VIA NASAL.}

Em nossos estudos foram analisados soros de 8 coelhos no 45 dia após imunização. Os resultados da atividade individual podem ser observados na tabela 8. Os ensaios foram feitos em quatriplicata.

Tabela 8: Títulos de atividade bactericida dos soros de coelhos imunizados pela via intranasal 35 dias após imunização.

\begin{tabular}{|c|c|c|c|c|}
\hline $\begin{array}{c}\text { Cepa } \\
\text { B:4,7:P1.15,19 }\end{array}$ & \multicolumn{4}{l|}{} \\
\hline & Coelho 1 & Coelho 2 & Coelho 3 & Coelho 4 \\
\hline & $1 / 4$ & $1 / 128$ & $1 / 4$ & $1 / 8$ \\
\hline & $1 / 4$ & $1 / 64$ & $1 / 2$ & $1 / 16$ \\
\hline & $1 / 4$ & $1 / 32$ & $1 / 8$ & $1 / 32$ \\
\hline & $1 / 2$ & $1 / 64$ & $1 / 16$ & $1 / 16$ \\
\hline & \multicolumn{4}{|l|}{} \\
\hline & Coelho 5 & Coelho 6 & Coelho 7 & Coelho 8 \\
\hline & $1 / 64$ & $1 / 128$ & $1 / 1024$ & $1 / 1024$ \\
\hline & $1 / 128$ & $1 / 64$ & $1 / 2048$ & $1 / 2048$ \\
\hline & $1 / 64$ & $1 / 256$ & $1 / 2048$ & $1 / 2048$ \\
\hline & $1 / 128$ & $1 / 128$ & $1 / 2048$ & $1 / 2048$ \\
\hline
\end{tabular}

Um ponto de extrema importância no desenvolvimento de uma vacina contra o meningococo B é a avaliação da capacidade protetora dos anticorpos induzidos pela preparação vacinal que é medida por meio da atividade bactericida, ou seja, lítica dos anticorpos induzidos tentando correlacionar com avidez do anticorpo produzido. Neste estudo os títulos de anticorpos bactericidas foram determinados pela diluição do soro onde houve uma redução de $50 \%$ das colônias bacterianas. Os ensaios foram feitos em quadriplicata. 
Observamos diferenças na capacidade dos anticorpos bactericidas produzidos nos diferentes coelhos quanto à capacidade de destruir o meningococo com soros de coelhos imunizados com whole cells de $N$. meningitidis ou whole cells de bactérias do gênero Neisseria. A capacidade de destruição dos meningocos dependeu do esquema isto é das doses administradas e das cepas de bactérias utilizadas.

Devemos levar em consideração que anticorpos IgG para vários peptídeos da membrana externa bacteriana foram produzidos. 


\section{V - DISCUSSÃO}

Um dos objetivos do presente estudo foi analisar a atividade protetora de anticorpos IgG produzidos em coelhos após imunização nasal com whole cells de $N$. lactamica, $N$. meningitidis $B, N$. meningitidis $c$ (isolada de carreador) e $N$. sicca. Foram empregados em nossos estudos como modelo animal coelhos machos albinos adultos normalmente utilizados nos estudos com outros patógenos como descrito na literatura (Suckow et al., 1995, 1996, 2002; Marin et al., 1995; Hamasur et al., 2003; Haile et al., 2004; Jiang et al., 2005; Mikszta et al., 2005).

A escolha do modelo coelho justifica-se por ser considerado um modelo mais representativo quando comparado a humanos, após o modelo murino para testes de vacinas antes de serem administradas em humanos.

Primeiramente por meio de imunização de coelhos com diferentes esquemas de imunização isto é, diferentes quantidades de bactérias, observamos que o emprego de concentrações maiores de bactérias, e também do microrganismo são necessárias para um melhor estímulo, quando utilizamos a via de imunização nasal , provavelmente em decorrência de células presentes nos sítios efetores de mucosa.

Com base nos resultados obtidos, foi observado que a imunização de coelhos adultos com whole cells de bactérias desenvolveram boa resposta humoral, que pode ser verificada pelos altos títulos de anticorpos do isótipo lgG produzidos no soro após imunização nasal.

Outro objetivo das investigações é alcançar uma formulação efetiva que induza proteção duradoura principalmente na porta de entrada do microrganismo, dispensando o uso de seringas e diminuindo o custo de produção. Assim, diversos grupos de pesquisadores têm direcionado seus esforços para pesquisar preparações vacinais que estimulem imunidade pela via de mucosa (Saunders et al., 1999; Haneberg et al., 2001; Katial et al., 2002), utilizando modelo camundongo ou humano.

Após a escolha e caracterização imunoquímica das cepas por SDS-PAGE e Immunoblot utilizando o anticorpo monoclonal $8 \mathrm{C} 7 \mathrm{Br} 1$ selecionamos cepas que apresentavam o antígeno reconhecido pelo anticorpo monoclonal (De Gaspari, 2000b).

O perfil da resposta imunológica foi analisado pela pesquisa de anticorpos circulantes no soro de coelhos imunizados com whole cells empregando-se a técnica de 
ELISA, o que permitiu a detecção de anticorpos do isótipo IgG de reatividade homóloga e heteróloga. A técnica de Immunoblotting permitiu a avaliação qualitativa da especificidade dos anticorpos induzidos.

A resposta imune independente da cepa utilizada pode ser considerada heterogênea, entretanto vários antígenos de alto peso molecular foram reconhecidos independentemente do esquema de imunização utilizado e da cepa de bactéria utilizada.

As proteínas, principalmente, em torno de 70kDa são descritas na literatura como proteínas reguladas pelo ferro que são expressas por várias cepas de meningococos e que induzem anticorpos com atividade bactericida. Trabalhos de Pintor et al. (1998), Troncoso et al. (2002), mostram que essas proteínas de alto peso (60 a $100 \mathrm{kDa}$ ); as iron regulated proteins são comuns a várias cepas de meningococos.

Notou-se ainda que outros antígenos como os de $80 \mathrm{kDa}$ foram reconhecidos independente da cepa e do esquema de imunização utilizado.

A capacidade protetora dos anticorpos foi verificada por meio de ensaio que determina a atividade lítica dos anticorpos mediada por complemento. Em vista dos títulos bactericidas obtidos por meio deste ensaio, notou-se que houve a indução de anticorpos que causam a lise da bactéria mediada pelo sistema complemento que variou também de acordo com a cepa e esquema de imunização utilizado.

Goldschneider et al. (1969), sugeriram que títulos mínimos de anticorpos bactericidas suficientes para fornecer proteção eram $>4$ para o sorogrupo C. Considerando que os dados descritos na literatura, principalmente de estudos préclínicos de imunogênicidade de preparações vacinais existentes contra os meningococos dos sorogrupos A, B e $C$, em que títulos bactericidas acima de 1/4 mostram-se significativos para a eliminação dos meningococos, pode-se concluir que os títulos de anticorpos bactericidas presentes nos soros dos coelhos imunizados pela via nasal são bastante satisfatórios.

Nos resultados dos nossos estudos não obtivemos uma boa correlação entre a atividade bactericida no soro e os títulos de anticorpos detectados por meio de ELISA, principalmente quando os coelhos foram imunizados só com whole cells de $N$. lactamica, ou os padrões antigênicos por meio de immunoblot, quando analisamos os 
coelhos imunizados pela via intranasal. Pode-se discutir que Neisseria spp. não patogênicas são melhores opções para as vacinas meningocócicas, entretanto o perfil antigênico das bactérias comensais é pobremente entendido, e outros epítopos de reatividade cruzada que induzem proteção contra a infecção meningocócica ainda não foram definidos (Poolman \& Berthet, 2001). Resultados estes que justificam a relevância de nossas pesquisas com intuito de contribuirmos nesta área do conhecimento.

$N$. lactamica é um organismo comensal intimamente relacionado a $N$. meningitidis, o agente causador da doença meningocócica. N. lactamica compartilha muitos antígenos comuns com $N$. meningitidis, mas não apresenta cápsula polissacarídica nem o antígeno de subtipo Por A. Estudos de portadores têm demonstrado que N. lactamica é encontrada na nasofaringe de crianças pequenas ao mesmo tempo em que o encontro de meningococos é raro. No entanto, a imunidade natural contra a doença meningocócica desenvolvida durante este período e a presença de Neisseria comensal está implicado no desenvolvimento de imunidade. Recentes pesquisas têm estudado os antígenos que podem ser responsáveis pela indução de resposta de anticorpos de reatividade cruzada, os quais têm demonstrado que vacinas baseadas em $N$. lactamica podem proteger contra a doença meningocócica (Gorringe et al., 2005a). O potencial de efetividade e prevenção destas vacinas contra a doença meningocócica atualmente é motivo de discussão.

A meta deste estudo foi analisar a resposta sistêmica de coelhos imunizados com whole cells de $N$. lactamica, $N$. meningitidis, $N$. sicca e $N$. meningitidis $c$ após imunização intranasal no sentido de tentar contribuir para o esclarecimento da indução de imunidade ao nível de mucosa. Nós verificamos que esta via de apresentação é efetiva em vários aspectos. Uma vez que os meningococos são patógenos estritamente humanos, um modelo animal que correlata com a boa eficácia em humanos não existe. No entanto, o desenvolvimento de atividade bactericida e de proteção em modelos animais é o melhor disponível no momento e correlaciona-se com o potencial de indução da resposta protetora em humanos (Holst et al., 2003).

Estudos recentes realizados em nosso laboratório utilizando modelo coelho (Seneme, 2005) demonstraram que quando utilizamos a via de imunização nasal com 
diferentes preparações antigênicas de NOMV de N. meningitidis $B$ existe a necessidade de uma maior quantidade de antígeno para estimulação do sistema imune de mucosa, quando os coelhos foram imunizados pela via intranasal, comparado os esquemas utilizados com o esquema de imunização pela via parenteral. Como coelhos são considerados uma população outbred, esta resposta também apresentou uma heterogeneidade quanto ao título de anticorpos produzidos e especificidade dos anticorpos IgG quando analisados por meio de Immunoblot relacionando se muito bem com o que acontece com a população quando recebe uma vacina. Outro estudo em nosso laboratório (Coutinho, 2002) mostrou que quando utilizamos as mesmas preparações antigênicas que utilizamos no modelo coelho em camundongos isogênicos imunizados pela via nasal estes apresentaram um padrão mais homogêneo de resposta imune. Mais estudos estão em andamento em nosso laboratório utilizando um número maior de coelhos. Atualmente encontramos restrições quanto à utilização de animais para estudos. Uma vez estabelecido os caminhos à autorização de um maior número de animais será necessário.

Vários estudos têm demonstrado que a taxa de portadores para N. lactamica é alta entre crianças pequenas. O melhor destes estudos, realizado por Gold e colaboradores na cidade de Danbury (Connecticut, EUA) em 1978, no qual foram estudados portadores assintomáticos de $N$. meningitidis e $N$. lactamica em crianças entre três meses e dezessete anos de idade. Grupos de crianças entre seis e oito anos de idade foram submetidos à coleta com swab na nasofaringe seis vezes durante o período de um ano para determinar a taxa de aquisição para estes organismos. Foi observado que a taxa de portadores de meningococos foi muito baixa nas crianças pequenas, enquanto os portadores de $N$. lactamica alcançaram o pico de $21 \%$ aos dezoito meses de idade. Em adição, este estudo demonstrou que estas crianças adquiriram $N$. lactamica numa taxa muito mais alta do que as crianças mais velhas. Neste estudo foi observado que $59 \%$ das crianças que foram testadas eram portadores das bactérias $N$. lactamica pelo menos uma vez até o quarto ano de idade, onde $7 \%$ apresentavam $N$. meningitidis na orofaringe. Somente três crianças inicialmente foram positivas para $N$. meningitidis onde posteriormente foram positivas para $N$. lactamica, e a situação inversa não foi observada. No Brasil ainda não temos até o momento este 
tipo de estudo como os descritos na literatura realizado em diferentes paises. No entanto selecionamos as nossas cepas baseando-se na expressão do antígeno de 5060kDa (De Gaspari, 2000b).

O interesse no desenvolvimento de uma vacina antimeningocócica efetiva é que ela seja independente de sorogrupos ou sorotipos, desta forma vacinas baseadas em vesículas de proteínas de membrana externa excretadas, algumas delas reguladas pelo ferro, mas todas mostrando alta reatividade cruzada e antígenos de reatividade cruzada. Em nossos esquemas de imunização utilizados observamos a produção de anticorpos de reatividade cruzada e de especificidade comum presente nas diferentes cepas de bactérias utilizadas (Tabela 7). Alguns investigadores também consideram a presença de proteínas de reatividade cruzada presentes em diferentes espécies ou gêneros de bactérias, como proteínas de $N$. lactamica, importantes no desenvolvimento da imunidade natural contra o meningococo (Plested et al., 2003). Vários antígenos de reatividade cruzada e vários antígenos conservados foram demonstrados em portadores ou na doença invasiva de $N$. meningitidis e espécies comensais, especialmente de N. lactamica (Pavliak et al., 2004). A correlação entre anticorpos bactericidas e a resposta de anticorpos para estes antígenos é ausente em experimentos com soro humano de pacientes convalescentes e voluntários saudáveis bem como com em camundongos não há resposta especificas no soro (Pollard \& Frasch, 2001).

Como discutido anteriormente, $N$. lactamica compartilha muitos antígenos com meningococo, e muitos destes serão responsáveis pela indução de anticorpos que irão conferir imunidade aos portadores e à doença meningocócica. Em estudos recentes realizados, foi utilizado anticorpos monoclonais para caracterizar 35 cepas de $N$. lactamica, foi observado que as cepas reagiram com anticorpos contra polissacarídeos capsulares de meningococos e/ou Por A, e somente duas das cepas reagiram com anticorpos PorB. No entanto, muitas das cepas de $N$. lactamica ligaram-se a um ou mais lipo-olissacarídeos (LOS) quando utilizados anticorpos monoclonais produzidos para meningococos. Baseados neste estudo, os autores especularam que os epítopos compartilhados de LOS podem desempenhar um importante papel no desenvolvimento da imunidade natural aos meningococos. O papel que LOS desempenha na produção 
de anticorpos de reatividade cruzada tem sido estudado e discutido em diferentes trabalhos (Gorringe, 2005). O anticorpo monoclonal 8C7Br1 utilizado no presente estudo é importante porque reconhece antígenos de reatividade cruzada para diferentes sorogrupos, sorotipos de $N$. meningitidis e que também estão presentes em N. lactamica.

Com o emprego da técnica de Immunoblot foram identificados vários antígenos de membrana externa de reatividade cruzada, incluindo a lipoproteína e LOS. Em nossos estudos pudemos também observar uma reatividade para a lipoproteína H8 principalmente quando os coelhos foram imunizados com $N$. lactamica. Vários antígenos de meningococos que fornecem proteção em modelos animais e/ou induzem anticorpos de atividade bactericida também estão presentes em $N$. lactamica, e podem ser parcialmente responsáveis pela indução de uma resposta que pode proteger contra a doença meningocócica. Estes incluem também as transferrinas de ligação de proteínas: NspA, NadA, lipoproteína 2086 e vários outros antígenos, identificados pela "vacinologia reversa" do genoma do meningococo sorogrupo B (Kelly \& Rappuoli, 2005).

Nosso estudo utilizando o modelo coelho no sistema de prime booster com whole cells de $N$. meningitidis e bactérias do gênero Neisseria mostrou que alguns antígenos se mostraram predominantes e que a estimulação dos mesmos variou de acordo com o protocolo experimental de imunização pela via nasal utilizando as cepas selecionadas (Tabela 7).

Técnicas de biologia molecular têm ressaltado ainda mais as similaridades entre $N$. meningitidis e N. lactamica. Um estudo usando surface-enhanced laser desorption ionization mass spectrometry (SELDI - MS) identificou a proteína de classe 2 ou 3 (Por B), NspA (22 kDa) e proteínas de classe 4 (RmpM) em OMV de $N$. lactamica. A caracterização de OMVs de $N$. lactamica por separação usando eletroforese em gel de poliacrilamida (SDS) seguida por cromatografia liquida (LC) - MS/MS também tem sido realizada. Analisando o genoma de meningococos, foram identificadas 31 proteínas de $N$. lactamica com homologia ao genoma de meningococos do sorogrupo B com pelo menos três peptídeos compartilhados e ainda mais 101 proteínas compartilhadas por 
um ou dois peptídeos. Isto confirma o alto grau de homologia entre as estruturas de superfície de meningococos e a superfície de N. lactamica (Vaughan et al., 2004).

Griffiss et al. (1991), realizaram um estudo experimental com cepas de $N$. lactamica, as quais induziram imunidade, sugeriram que um mecanismo de booster induziu imunidade contra a doença meningocócica. A possibilidade de uma vacina viva também vem sendo discutida, mas esta questão que concerne ao perfil antigênico das bactérias comensais ainda é pobremente entendido e os epítopos de reatividade cruzada não foram identificados. OMVs de $N$. lactamica têm sido preparadas e usadas para imunizar animais de laboratório (camundongos e coelhos). Anticorpos que tem reatividade cruzada com $N$. meningitidis por immunoblot têm sido demonstrados, mas a atividade bactericida contra $N$. meningitidis não foi observada. Em adição, um esquema de imunização com duas doses com OMV de $N$. lactamica seguida de um booster com OMV de meningococos produziu um aumento da atividade bactericida quando comparado com três doses de OMV de $N$. lactamica ou uma única dose de OMV de $N$. meningitidis, indicando que $N$. lactamica pode sensibilizar o sistema imune para uma resposta de reatividade cruzada com N. meningitidis (Sanchez et al., 2002a; Sanchez et al., 2002b). Por meio de ELISA estes dados foram confirmados em nossos estudos. Observações ainda mais interessantes sobre a atividade de anticorpos de reatividade cruzada, foram que a adsorção do soro de um paciente convalescente de doença meningocócica com $\mathrm{N}$. lactamica aboliu completamente a atividade bactericida contra a cepa infectante. Uma clara evidência sobre o potencial de uma vacina baseada em $N$. lactamica foi proveniente de um estudo de Oliver e colaboradores (2002), que demonstraram que a imunização com whole cells de $N$. lactamica mortas, OMVs, ou pools de proteínas de membrana externa protegeram camundongos contra o desafio letal por vários isolados de meningococos dos sorogrupos $\mathrm{B}$ e $\mathrm{C}$ em um modelo de infecção por bacteremia. No entanto, não foi demonstrado a resposta de anticorpos bactericidas contra $N$. meningitidis, indicando que outros mecanismos possam estar envolvidos nesta proteção. Uma resposta de anticorpos que demonstram opsonofagocitose tem sido observada em coelhos imunizados com OMVs de $N$. lactamica, sugerindo que este mecanismo possa estar envolvido em uma resposta protetora. A proteção na ausência de anticorpos bactericidas tem sido observada por 
outros antígenos, como TbpA e a vacina derivada do genoma 2132 , demonstrando que anticorpos bactericidas podem não ser o único fator de proteção para as vacinas baseadas em proteínas de meningococos.

Um recente estudo demonstrou que OMVs de $N$. lactamica também são efetivas na geração de resposta imune de reatividade cruzada em camundongos quando administrados pela via intranasal (Sardinas et al., 2005). Em adição, estas OMVs são efetivos adjuvantes intranasais, aumentando grandemente a resposta de anticorpos quando foi co-administrado com antígenos de superfície da hepatite B. Em concordância com os estudos de Oliver e colaboradores (2002), os anticorpos de atividade bactericida não foram observados seguindo-se a imunização com OMVs de $N$. lactamica, mas a proteção foi observada em um modelo de camundongos neonatos de bacteremia meningocócica. Ainda mais, interessantes observações quanto às vacinas de OMV de $N$. lactamica foram feitas em outro estudo, no qual proteínas de classe 5 (Opa) de OMVs de meningococos interagiram com CEACAM1 de células de linfócitos CD4+ a qual levou a respostas de supressão, ativação, proliferação e indução de apoptose. A vacina de OMV examinada no mesmo sistema in vitro não induziu supressão ou apoptose. Mais evidências do potencial da vacina de Neisseria comensal foi fornecida por O’Dwyer e colaborades (2004), que reportaram uma proteína heteróloga de alto nível de expressão de uma vacina candidata NspA de meningococos, numa outra espécie de Neisseria comensal, $N$. flavences. NspA foi expressa em OMVs produzidas desta bactéria recombinante, e o anti-soro aumentou os mediadores de opsonofagocitose e proteção passiva em modelos de camundongos de bacteremia meningocócica. Este desenvolvimento demonstra o potencial de OMVs de Neisseria comensais como um sistema de distribuição para antígenos heterólogos de meningococos.

As vacinas experimentais iniciais de $N$. lactamica foram baseadas em células mortas pelo calor, mas é provável que ela possa ser reatogênica para o uso em humanos. As vacinas vivas intranasais também foram consideradas como sendo mimetizadoras do desenvolvimento da imunidade natural. No entanto, as questões de segurança e distribuição da vacina são difíceis de resolver, por isso ela não foi considerada como ideal para o uso. 
$N$. lactamica produz blebs na superfície de membrana da mesma maneira que $N$. meningitidis, desta forma é possível produzir OMVs de $N$. lactamica extraídas com deoxycholato igualmente a $N$. meningitidis. Isto permite que esta vacina baseada em OMV possa ser amplamente utilizada como a usada em Cuba, Brasil, Noruega, e mais recentemente na Nova Zelândia. O desenvolvimento do processo para OMVs de N.lactamica brevemente descrito (Gorringe, 2005), e OMVs com um diâmetro de aproximadamente $100 \mathrm{~nm}$ foram produzidas as quais foram morfologicamente indistinguíveis da similaridade produzida pelas OMVs de meningococos. Conforme os cuidados prévios de proteção usados para as OMVs da bactéria que cresceram sob condições de um meio limitado de ferro, também houve uma equivalente proteção no modelo de camundongos com bacteremia no qual as bactérias cresceram em meio sem restrição de ferro, e isto evitou o uso de um quelador de ferro no processo da produção. Um problema adicional encontrado foi a segurança de uma assepsia do processo e obtenção de um produto estéril. A esterilidade das vacinas de OMVs foram asseguradas pela inclusão do mercúrio Thimerosal conservante.

Como demonstramos em estudos anteriores o anticorpo monoclonal $8 \mathrm{C} 7 \mathrm{Br} 1$ apresenta reatividade com cepas de diferentes sorotipos e subtipos de $N$. meningitidis (De Gaspari, 2000b). Interessantemente, neste trabalho nos também observamos que Mab reconheceu os peptídeos de 50-60 kDa em espécies comensais analisadas. $\mathrm{O}$ alto grau de reatividade cruzada observado pelos estudos realizados por meio de immunoblot associados aos recentes resultados sugerem que este peptídeo conservado entre os meningococos pode ser um candidato disponível para uma vacina utilizando cepas comensais como $N$. lactamica. Entretanto devemos ressaltar a importância da escolha do adjuvante apropriado. Também recentemente em nosso laboratório Carmo, (2005), utilizando a proteína de classe 5C purificada e como adjuvantes como a B. pertussis, toxina colérica e LPS (L8 e L379) em diferentes esquemas de imunização avaliaram a modulação da resposta imune contra esta proteína administrada pela via intranasal em camundongos BALB/c adultos e neonatos/ jovens. Como indicador de imunidade protetora foram avaliados o índice de avidez dos anticorpos e a atividade bactericida do soro dos animais imunizados. Títulos expressivos de anticorpos de isótipos IgG e IgM foram detectados no soro de 
camundongos neonatos/ jovens e adultos, após a imunização, com índices de avidez que variaram de intermediário a alto com boa correlação com a atividade bactericida. Todos os adjuvantes utilizados foram capazes de aumentar a resposta imune contra a proteína de classe $5 \mathrm{C}$ por meio de dois esquemas de imunização em camundongos neonatos/ jovens e adultos. No entanto, LPS foi melhor para uso em camundongos adultos, enquanto que a $B$. pertussis foi melhor para uso em camundongos neonatos jovens. A via intranasal foi capaz de sensibilizar as células do sistema imune, as quais foram rapidamente estimuladas pela via intramuscular. Os dados sugerem que a proteína de classe $5 \mathrm{C}$ é importante na indução de imunidade de mucosa para a $N$. meningitidis $B$.

O grande número de cepas de $N$. meningitidis atribuído a reatividade com diferentes gêneros de bactérias e cepas comensais que expressaram a proteína de 50$60 \mathrm{kDa}(70 \%)$ e a falta de atividade bactericida sugerem que mecanismos diferentes possam estar envolvidos. Além disso, o peptídeo de 50-60 kDa foi reconhecido quando os coelhos foram imunizados pela via intranasal com whole cells de $N$. meningitidis, $N$. lactamica , N. meningitidis $c$ e foi observada atividade bactericida e produção de anticorpos IgG em coelhos de boa avidez sem o uso de adjuvantes. Como em nossos estudos quando utilizamos a proteína de classe $5 \mathrm{C}$ purificada a pesquisa de adjuvantes para a utilização do peptídeo de 50 kDa purificado será um ponto importante de futuras pesquisas.

Está claro que proteínas de membrana podem induzir uma resposta imune funcional contra a doença meningocócica do sorogrupo $B$, no entanto, nenhumas das vacinas induzem o desenvolvimento de uma proteção universal devido a grande heterogeneidade das proteínas de superfície de membrana expostas. A fraca imunidade de reatividade cruzada induzida pelas vacinas de OMV tem complementado as pesquisas para um antígeno de membrana externa (ou grupos de antígenos), os quais induzem anticorpos funcionais e estão presentes em todas as cepas de meningococos. Tais antígenos, se eles estiverem presentes em todas as cepas independentemente de sorogrupos, podem ser a base para uma vacina antimeningocócica verdadeira, que possa eliminar o potencial problema de "switching" 
capsular nas cepas patogênicas que procede nas vacinas de polissacarídeos (Kim et al., 1989; Cadieux et al., 1999; Morley \& Pollard, 2001).

A inoculação nasal com whole cells mortas de $N$. lactamica falharam na indução de anticorpos bactericidas detectáveis contra N. meningitidis $B$ (Tunes \& De Gaspari, 2002; Néri et al., 2003; Tunes et al., 2003). Sendo assim outros mecanismos como a opsonofagocitose pode estar participando e está em estudo em nosso laboratório.

Uma vez que uma variedade de fatores influencie os resultados da resposta imune de mucosa, então é difícil para julgar se a vacina candidata não é aceitável ou imunogênica como indutora dos sítios do sistema de imunidade de mucosa ou se o epitélio eventualmente possa não permitir a transocitose eficientemente, contudo mais estudos são necessários.

Este estudo teve em foco primeiramente a medida de anticorpos de respostas para os antígenos de whole cells no modelo coelho. A administração pela via intranasal de $N$. lactamica, $N$. sicca, $N$. meningitidis e $N$. meningitidis $c$ sem adjuvantes induziram aumentos significativos de anticorpos IgG com especificidade direcionada para diferentes antígenos entre eles os de 50 kDa, H8 (32 kDa), NspA (22 kDa) e NadA (190 kDa), proteínas estas presentes na membrana externa de meningococos. Anticorpos contra estruturas de superfície do patógeno contidos nas vacinas de wholecell provavelmente desempenham um importante papel na superfície de mucosa. Embora não tivemos a produção de altos títulos de anticorpos bactericidas para $N$. meningitidis anticorpos de alta avidez foram produzidos. A falta desta atividade talvez se deva a ausência da Por A presente em cepas de meningococos (Gorringe, 2005).

Mais estudos em nosso laboratório referentes à imunidade de mucosa estão sendo investigados, especialmente utilizando NOMV de N. lactamica.

Apesar de, até o momento, não existir o antígeno que proporcione um nível de eficácia ideal, algumas preparações vacinais foram desenvolvidas e vêm sendo utilizadas contra o meningococo B (Sierra et al., 1991; Bjune et al., 1991; Boslesgo et al., 1995; Claasen et al., 1996). O principal objetivo das pesquisas é alcançar uma formulação efetiva que atue em dose única e que induza proteção duradoura (especialmente na porta de entrada do microrganismo), dispensando assim o uso de seringas e diminuindo o custo de produção. Assim, diversos grupos de pesquisa têm 
direcionado seus esforços para a pesquisa de preparações vacinais que estimulem a imunidade pela via de mucosas (Saunders et al., 1999; Haneberg et al., 2001; Katial et al., 2002).

Verificamos ainda por meio de ELISA que houve a detecção de anticorpos presentes nos soros de coelhos com boa avidez, entretanto a atividade bactericida variou de acordo com a cepa utilizada e o esquema de imunização utilizado. Deve-se salientar que as maiorias das células B dentro de uma população clonal ativada revertem em células de memória que podem sobreviver por anos e quando ativadas sofrem novos ciclos de replicação formando novas células de memória garantindo assim a defesa contra um determinado microrganismo. Por isso no desenvolvimento de vacinas efetivas para qualquer patógeno é realizada a análise da persistência destes anticorpos. Um dos pontos chaves é verificar se a preparação antigênica utilizada foi capaz de induzir células de memória. Os resultados obtidos por meio de ELISA e análise por Immunoblot sugerem que células de memória são produzidas e quando novo estímulo é dado com cepas diferentes uma resposta para alguns antígenos é potencializada enquanto em outros casos novos clones passam a ser estimulados.

Os resultados da especificidade de anticorpos por "Immunoblotting" foram analisados no $45^{\circ}$ dia após a imunização. Seria interessante analisarmos a resposta de anticorpos IgA, visto que os coelhos foram imunizados pela via intranasal. Contudo, os resultados com a produção dos anticorpos IgG são interessantes pois anticorpos bactericidas e de alta avidez foram produzidos, mostrando assim a capacidade de ligação à antígenos dos mesmos.

Os mecanismos pelos quais $N$. meningitidis estabelece o estado de fisiopatologia ou a invasão da superfície mucosa do hospedeiro para causar septicemia e meningites ainda são desconhecidos. Estudos de microscopia eletrônica mostram que os meningococos se ligam seletivamente a células não ciliadas, alongadas, adjacentes no organismo (Nassif, 1999). Entre seis a doze horas após a infecção, vacúolos endocíticos contendo meningococos são vistos na porção apical de algumas células colunares não ciliadas. Posteriormente, os meningococos são observados no tecido sub-epitelial adjacente ao tecido linfóide. Estas observações sugerem que os meningococos penetraram a camada epitelial. 
A interação dos meningococos com o epitélio da nasofaringe pode ser um importante mecanismo por onde a bactéria estabelece um estado de portador ou de invasão do hospedeiro (Stephens et al., 1986; Wu et al., 1997). E está evidenciado que são várias as estruturas de superfície bacteriana que são críticas para a adesão e invasão que ocorre através da mucosa da nasofaringe, e que por sua vez são responsáveis pela resposta imune do hospedeiro. Estima-se que cerca de quinhentos milhões dentre as seis bilhões de pessoas no mundo são colonizadas pelos meningococos na nasofaringe. A taxa de portadores na nasofaringe de $N$. meningitidis é mais baixa em crianças pequenas e mais altas em adolescentes e jovens. A relação entre o estado de portador e a progressão da doença invasiva não está completamente entendido. Embora seja sugerido que a taxa total de portadores de meningococos não são responsáveis totalmente pelo prognóstico dos surtos da doença meningocócica, a colonização da nasofaringe é o primeiro passo para a doença invasiva, portanto, fatores associados com portadores podem ser elucidados para melhorar as medidas de proteção. Em crianças menores de dois anos de idade, as taxas de portadores de meningococos são cinco vezes menores do que nas crianças em idade escolar, sendo que as crianças pequenas portam uma taxa significativamente maior de $\mathrm{N}$. lactamica (Gold et al., 1978). Esta taxa reversa de estado de portador pode sugerir a possibilidade de que $N$. lactamica exerça um papel de proteção contra a colonização pelos meningococos.

$O$ desenvolvimento da imunidade natural contra $N$. meningitidis tem sido recentemente revisado, e está claro que os anticorpos desempenham um papel importante por meio da ligação das estruturas de superfície dos meningococos e ativação do complemento levando a fagocitose ou morte direta por efeito bactericida. Dados similares de portadores foram obtidos em um estudo recente em Gorringe (2005). N. lactamica é muito freqüente em crianças abaixo de cinco anos de idade sendo seis vezes mais comum neste grupo do que em portadores de $N$. meningitidis. $N$. lactamica também foi isolada mais freqüentemente do que $N$. meningitidis da nasofaringe de crianças do Norte da Nigéria. Dados de Faroe Islands na Europa, demonstraram uma associação negativa entre portadores de N. lactamica, doença meningocócica e portadores de meningococos numa área de alta incidência, contanto, 
futuras evidências demonstraram que $N$. lactamica protegeu contra a infecção meningocócica. Estudos posteriores de portadores foram realizados na Espanha, Turquia, Grécia e Nova Zelândia, sobre os casos de contato doméstico com a doença meningocócica e demonstraram uma alta incidência de portadores de $N$. lactamica numa taxa de $61 \%$ nas crianças de dois anos de idade. Outras informações sobre portadores de $\mathrm{N}$. lactamica foram obtidas num estudo longitudinal de 316 crianças. A taxa máxima de portadores foi de $44 \%$ na $56^{a}$ semana de idade, o estudo prorrogou-se até a $88^{\mathrm{a}}$ semana, e os isolados foram geneticamente idênticos durante este período com poucas evidencias de mudança das cepas. Os genótipos destes isolados foram heterogêneos, mas somente 11 das 75 crianças apresentaram mais do que um único isolado genotipicamente durante o período do estudo realizado.

Duas hipóteses alternativas para uma vacina baseada em $N$. lactamica foram postuladas baseadas nestas observações. A diversidade das cepas sugere que uma vacina baseada em multicomponentes de muitas cepas pode ser necessária, ou alternativamente, a longo termo os portadores de um único isolado sugerem que a vacina baseada numa única cepa pode ser efetiva no mecanismo de proteção.

Foi desenvolvido um modelo matemático da influencia de carreadores na infecção e doença, e o papel de $N$. lactamica como um imunógeno natural contra a infecção meningocócica sintomática e assintomática e os dados foram consistentes e fieis (Coen et al., 2000). Uma demonstração funcional da imunidade antimeningocócica induzida em portadores de N. lactamica foi a observação que as secreções nasais dos portadores de $N$. lactamica tem um efeito inibitório sobre a adesão de $N$. meningitidis nas células epiteliais orais em humanos (Andrade et al., 1986).

O papel da LOS na observação de proteção ainda não está claro. LOS de $N$. lactamica purificados não protegeram contra o desafio com meningococos, mas é possível que as vacinas experimentais contendo LOS em varias quantidades e talvez em uma forma nativa é mais imunogênica do que os antígenos de LOS purificados possam ser promissores. Ainda mais, o fracionamento do pools de antígenos por eletroforese demonstrou proteção contra o desafio por meningococos pelas frações que continham LOS, indicando que outros antígenos protéicos possam ser ao menos parcialmente responsáveis pela proteção observada. Subseqüentes estudos usando um 
modelo de proteção ativa e passiva em camundongos desafiados, por cepas não meningocócicas foram testadas e não induziram proteção contra N. lactamica.

Como preferencialmente o uso de conservante não está incluído, o processo de esterilização usando filtro foi desenvolvido. As OMVs de N. lactamica tendem a formar grandes agregados mais rapidamente do que OMVs de meningococos, e portanto um sistema de tampão foi criado que aumentou o potencial zeta, ou seja a carga superficial das partículas das OMVs, inibindo desta forma a tendência natural à agregação destas partículas.

Atualmente está sendo preparada a vacina de OMV de N. lactamica para o uso na fase I de segurança e estão sendo feitas triagens de imunogenicidade em voluntários homens adultos, os quais irão determinar se as OMVs destes organismos tem a similar segurança ao perfil das vacinas de OMVs de meningococos e se as respostas imune de reatividade cruzada observadas em ratos serão replicadas em humanos (Gorringe, 2005). A observação de que a presença de N. lactamica induziu resposta de anticorpos bactericidas em crianças podem encorajar que similares respostas possam ser observadas em humanos em contraste com as observações feitas em camundongos. A resposta de anticorpos bactericidas poderá ser determinada contra o painel de cepas meningocócicas prevalentes na UK que representam diversas linhagens clonais, bem como a habilidade destas cepas de estimular a produção de anticorpos e a opsonofagocitose.

Somente as vacinas baseadas em OMVs de meningococos são eficazes para o meningococo do sorogrupo B como aquelas desenvolvidas em Cuba e Noruega (Frasch et al., 2001; Gorringe et al., 2005a;). Muitas formulações foram feitas e estão recentemente nas fases pré-clinicas e no inicio da fase clínica, mas nenhuma delas podem ser aceitas amplamente e sem fortes perspectivas de sucesso. Antígenos individuais aumentam as questões que concernem a variação na diversa cadeia de isolados de meningococos, e não é provável que um único antígeno candidato possa ter sucesso a longo termo. As vacinas de OMV baseadas em $N$. meningitidis são dominadas pelas respostas a antigenos Por $A$, os quais definem o subtipo, e ainda assim foram desenvolvidas vacinas multivalentes baseadas em Por A, estas, no entanto, são reformuladas freqüentemente devido às rápidas mudanças observadas 
nos subtipos prevalentes, e o número de subtipos requeridos para uma vacina efetiva, ainda torna a vacina complexa e cara (Claassen et al., 1996; Tondella et al., 2000; Urwin et al., 2004). Uma alternativa tem sido proposta para a modificação genética de $N$. meningitidis para a produção de uma vacina de OMV efetiva, na qual o papel chave seria que os antígenos fossem regulados por ativação ou supressão para melhorar a resposta de reatividade cruzada. Outras aproximações são baseadas em LOS como uma vacina alvo e demonstra-se promissora em modelos animais, mas vacinas conjugadas precisam ser produzidas para assegurar a imunogenicidade da vacina; em adição, há as questões relacionadas a variabilidade de LOS entre as cepas e a acessibilidade das regiões conservadas da superfície de LOS. Uma vacina potencialmente efetiva baseada em polissacarídeos do sorogrupo B modificados quimicamente tem aumentado as questões quem concernem à aceitabilidade para o uso em humanos, porque ela pode aumentar os anticorpos que reagem com tecidos humanos. Embora não tenham sido observados totalmente os efeitos de segurança e imunogenicidade em voluntários adultos, está claro que evidências podem ser requeridas para demonstrar a sua segurança.

Poolman e Bethet (2001) descreveram a vacina ideal para o sorogrupo B como sendo:

- Segura e imunogênica na população pediátrica;

- Capaz de induzir a proteção contra uma variedade de cepas;

- Custo acessível e fácil de ser manufaturada em larga escala.

Uma vacina de OMV de $N$. lactamica que tem o potencial de cumprir com todos estes critérios como portador natural de crianças tem demonstrado induzir imunidade de reatividade cruzada contra $N$. meningitidis. Estudos com modelos animais embora não mimetizem com precisão a patogênese da doença em humanos, demonstram proteção contra isolados clínicos de diferentes linhagens clonais. $N$. lactamica tem uma vantagem adicional sobre $N$. meningitidis por ser um organismo seguro e não requer todo o aparato que é necessário para a cultura em larga escala de $N$. meningitidis. Desta forma, esta considerável experiência na manufatura de vacinas de OMV que podem ser diretamente aplicadas para uma vacina usando esta cepa comensal ao invés da patogênica. É claro que alguns destes benefícios são atualmente 
especulativos, baseados somente em evidências pré-clínicas, e uma clara resposta para a questão de como $N$. lactamica fornece uma vacina efetiva para prevenir a doença meningocócica somente será respondida através de uma avaliação em humanos.

O uso de novas tecnologias para a pesquisa de novas vacinas antimeningocócicas para o sorogrupo B é de grande interesse do Ministério da Saúde e o nosso grupo desde 1999 tem desenvolvido projetos e estudos com o objetivo de estabelecer um novo método de imunização. 


\section{VI - CONCLUSÃO}

Os coelhos imunizados com "whole cells" de cepas de N. meningitids e bactérias do gênero Neisseria pela via nasal em nosso estudo permitiram concluir que:

1- Que "whole cells" destas bactérias quando administradas pela via intranasal em coelhos foram capazes de induzir imunidade sistêmica. Essa imunidade foi evidenciada principalmente pelos níveis de anticorpos (dos isótipos lgG) presentes no soro.

2- Houve a indução de anticorpos que podem ser atribuídos principalmente para proteínas H8, NspA, NadA e $50 \mathrm{kDa}$, proteínas de alto peso molecular; e proteínas de reatividade cruzada reconhecidas pelos anticorpos monoclonais, consideradas importantes no combate da infecção meningocócica.

3- Pudemos observar diferenças entre os títulos de anticorpos produzidos para cepas homólogas e heterólogas quando os soros foram analisados por meio de ELISA.

4- A cepa de bactéria utilizada foi importante na quantidade de anticorpos produzidos e na especificidade dos mesmos.

5- A produção de anticorpos bactericidas e avidez dos mesmos também estão correlacionados com a cepa de bactéria e protocolo de imunização utilizado.

6- Os animais não perderam peso após a imunização nasal mesmo quando utilizamos "whole cells" de N. lactamica, N. meningitidis $B, N$. meningitidis isolada de carreador e N.sicca. 


\section{VII - Referências Bibliográficas}

AASE, A.; BJUNE, G.; HOIBY, E.A.; ROSENQVIST, E.; PEDERSEN, A.K.; MICHAELSEN, T.E. Comparison among opsonic activity, antimeningococcal immunoglobulin $\mathrm{G}$ response, and serum bactericidal activity against meningococci in sera from vaccinees after immunization with a serogroup B outer membrane vesicle vaccine. Infect. Immun., v. 63, p. 3531-3536, 1995.

ABDILLAHI, H.; POOLMAN, J. T. Typing of group-B Neisseria meningitidis with monoclonal antibodies in the whole-cell ELISA. J. Med. Microbiol., v. 26, p. 177180, 1988.

ACHTMAN, M.; WALL, R. A.; BOPP, M.; KUSECEK, B.; MORELLI, G.; SAKEN, E.; HASSAN KING, M. Variation in class 5 protein expression by serogroup $A$ meningococci during a meningitis epidemic. J. Infect. Dis., v. 164, p. 375-382, 1991.

ALONSO, J. A. N. La inmunizacioón activa frente a Neisseria meningitidis serogrupo B. Enferm. Infec. Microbiol. Clin., v. 21, p. 513-519, 2003.

ANDRADE, J. R.; MARQUES, M. C.; DE SANTA ROSA, M. R. Nasal secretions of Neisseria lactamica carriers have an inhibitory effect on Neisseria meningitidis attachment to human oroepithelial cells. Mem. Inst. Oswaldo Cruz, p. 453-57, 1986.

ARKING, D.; TONG, Y.; STEIN, D. C. Analysis of lipooligosaccharide biosynthesis in the Neisseriaceae. J. Bacteriol., v. 183, p. 934-941, 2001 b.

ARUMUGHAM, R.; FORTUNA-NEVIN, M.; MOUNTZOUROS, K. Development of lipooligosaccharide-protein conjugate vaccines against group B Neisseria meningitidis. Proceedings of the Fifth Conference of the International Endotoxin Society, p. 52, 1998.

ASANUMA, H.; HODSON THOMPSON, A.; IWASAKI, T.; SATO, Y.; INABA, Y.; AIZAWA, C.; KURATA, T.;TAMURA, S. Isolation and characterization of mucosal nasal-associated lymphoid tissue. J. Immunol. Meth,, v. 202, p. 123, 1997

ASHTON, F. E.; RYAN, J. A.; MICHON, F.; JENNINGS, H. J. Protective efficacy of mouse serum to the $N$-propionyl derivative of meningococcal group $B$ polysaccharide. Microbiol. Pathog., v. 6, p. 455-458, 1989.

AYALA, P.; LIN, L.; HOPPER, S.; FUKUDA, M. Infection of epithelial cells by pathogenic Neisseria reduces the levels of multiple lysosomal constituents. Infect. Immun., v. 66, p. 5001-5007, 1998.

BABIOR, B. M. The respiratory burst of phagocytes. J. Clin. Invest., v. 73, p. 599-601, 1984.

BENNETT, J. S.; GRIFFITHS, D. T.; MCCARTHY, N. D.; SLEEMAN, K. L. Genetic Diversity and Carriage Dynamics of Neisseria lactamica in Infants. Infection And Immunity, p. 2424-2432, 2005. 
BERG, S.; TROLLFORS, B.; ALESTIG, K.; JODAL, U. Incidence, serogroups and casefatality rate of invasive meningococcal infections in a Swedish region 1975-1989. Scand. J. Infect. Dis., v. 24, p. 333-338, 1992.

BERNSTEIN, J. M.; REDDY, M. S.; SCANNAPIECO, F. A.; FADEN, H. S.; BALLOW, M. The microbial ecology and immunology of the adenoid: implications for otitis media. Ann. NY Acad. Sci., v. 830, p. 19-31, 1997.

BEUTLER, B.; CERAMI, A. Cachectin-Tumour necrosis factor: a cytokine that mediates injury initiated by invasive parasites. Parasitol Today, v. 3, p. 345-346, 1987.

BEUTLER, B.; KROCHIN, N.; MILSARK, I. W.; LUEDKE, C.; CERAMI, A. Control of cachectin (tumor necrosis factor) synthesis: mechanisms of endotoxin resistance. Science, v. 232, p. 977-980, 1986.

BJORVATN, B.; LUND, V.; KRISTIANSEN, B. E; KORSNES, L.; SPANNE, O.; LINDQVIST, B. Applications of restriction endonuclease fingerprinting of chromosomal DNA of Neisseria meningitidis. J. Clin. Microbiol., v. 19, p. 763-765, 1984.

BJUNE, G.; HOIBY, E. A.; GRONNESBY, J. K. Effect of outer membrane vesicle vaccine against group B meningococcal disease in Norway. Lancet., v. 338, p. 1093-1096, 1991.

BORGHESI, C.; REGOLI, M.; BERTELLI, E.; NICOLETTI, C. Modifications of the follicle-associated epithelium by short-term exposure to a non-intestinal bacterium. J. Pathol., v. 180, p. 326-332, 1996.

BORROW, R.; CARLONE, G. M. Serogroup B and C serum bactericidal assays. Meningococcal vaccines. Methods in molecular medicine, p. 289-304, 2001.

BOSLEGO, J.; GARCIA, J.; CRUZ, C. Efficacy, safety, and immunogenicity of a meningococcal group B (15:P1.3) outer membrane protein vaccine in Iquique, Chile Chilean National Committee for meningococcal disease. Vaccine, v. 13, p. 821829, 1995.

BOVRE, K. Family VIII. Neisseriaceae Prevot. Manual of Systematic Bacteriology, v. 1, p. 288-309, 1984.

BRANDTZAEG, P. Humoral immune response patterns of human muscosae; inductions and relation to bacterial respiratory tract infections. J. Infect. Dis., v. 165, p. 51675176, 1992.

BRANDTZAEG, P.; HALSTENSEN, A.; KIERULF, P.; ESPEVIK, T.; WAAGE, A. Molecular mechanisms in the compartmentalized inflammatory response presenting as meningococcal meningitis or septic shock. Microb. Pathog., v. 13, p. 423-431, 1992.

BRANDTZAEG, P.; MOLLNES, T. E.; KIERULF, P. Complement activation and endotoxin levels in systemic meningococcal disease. J. Infect. Dis., v. 160, p. 5865, 1989. 
BRANDTZAEG, P.; PRYDZ, H. Direct evidence for an integrated function of $\mathrm{J}$ chain and secretory component in epithelial transport of immunoglobulins. Nature, v. 311, p. 71-73, 1984.

BRAUN, J. M.; BEUTH, J.; BLACKWELL, C. C.; GIERSEN, S; HIGGINS, P. G.; TZANAKAKI, G.; UNVERHAU, H.; WEIR, D. M. Neisseria meningitidis, Neisseria lactamica and Moraxella catarrhalis share cross-reactive carbohydrate antigens. Vaccine, v. 22, p. 898-908, 2004.

BRÖKER, M. Development of new vaccines against meningococcal disease. Arzneimittelforschung, v. 53, p. 805-813, 2003.

BROOKS, R. B.; WOODS, C. W.; ROSENSTEIN, N. E. Neisseria meningitidis outbreaks in the United States, 1994-2002. Abstracts of the 41st Annual Meeting of the Infectious Diseases Society of America, p. 81-82, 2003.

BRUGE, J.; MOULIN, J. C.; DANVE, B. Evaluation of the inocuity of a group B meningococcal polysaccharide conjugate in hyperimmunized, pregnant cynomolgus monkeys and their offspring. Proceedings of the 10th International Pathogenic Neisseria Conference, p. 222, 1996.

CADIEUX, M.; PLANTE, M.; RIOUX, C.; HAMEL, J.; BRODEUR, B.; MARTIN, D. Bactericidal and cross-protective activities of a monoclonal antibody directed against Neisseria meningitidis NspA outer membrane protein. Infect. Immunol., v. 67, p. 4955-4959, 1999.

CARMO, A. M. S. Estudo da imunogenicidade da proteína de classe 5C de Neisseria meningitidis B em camundongos imunizados pela via nasal. (Dissertação de Mestrado). São Paulo (SP): Secretaria de Estado da Saúde, 2005.

CARR, R. M.; LOLACHI, C. M.; ALBARAN, R. G.; RIDLEY, D. M.; MONTGOMERY, P. C.; O'SULLIVAN, N. L. Nasal-associated lymphoid tissue is an inductive site for rat tear IgA antibody responses. Immunol. Invest., v. 25, p. 387, 1996.

CARTWRIGHT, K. A. V.; JONES, D. M.; SMITH, A. J.; STUART, J. M.; KACZMARSKI, E. B.; PALMER, S. R. Influenza A and meningococcal disease. Lancet, v. 338, p. 554-557, 1991.

CARTWRIGHT, K.; MORRIS, R.; RUMKE, H. Immunogenicity and reactogenicity in UK infants of a novel meningococcal vesicle vaccine containing multiple class 1 (PorA) outer membrane proteins. Vaccine, v. 17, p. 2612-2619, 1999.

CAUGANT, D. A. Population genetics and molecular epidemiology of Neisseria meningitidis. APMIS, v. 106, p. 505-525, 1998.

CHACKERIAN, B.; LOWY, D. R; SCHILLER, J. T. Conjugation of a self-antigen to papillomavirus-like particles allows for efficient induction of protective autoantibodies. J. Clin. Invest., v. 108, p. 415-423, 2001.

CHENG, H.; LEBLOND, C. P. Origin, differentiation and renewal of the four main epithelial cell types in the mouse small intestine. I. Columnar cell. Am. J. Anat, v. 141, p. 461-479, 1974. 
CHIEN, Y. W. Biopharmaceutics basis for transmucosal delivery. S.T.P. Pharma. Sci., v. 5, p. 257-275, 1995.

CHIEN, Y. W.; SU, K. S. E.; CHANG, S. F. Nasal Systemic Drug Delivery. Marcel Dekker, 1989.

CLAASEN, I.; MEYLIS, J.; VAN DER LEY, P. Production, characterization and control of a Neisseria meningitides hexavalent class 1 outer membrane protein containing vesicle vaccine. Vaccine, v. 14, p. 1001-1008, 1996.

CLARKE, S. H.; HUPPI, K.; RUEZINSKY, D.; STAUDT, L.; GERHARD, W.; WEIGERT, M. Inter- and intraclonal diversity in the antibody response to influenza hemagglutinin. J. Exp. Med., v. 161, p. 687-704, 1985.

COEN, P.G.; CARTWRIGHT, K.; STUART, J. Mathematical modeling of infection and disease due to Neisseria meningitides and Neisseria lactamica. Int. J. Epidemiol., v. 29 , p. $180-188,2000$.

COMANDUCCI, M.; BAMBINI, S.; BRUNELLI, B.; ADU-BOBIE, J.; ARICÒ, B.; et al. NadA, a novel vaccine candidate of Neisseria meningitidis. J. Exp. Med., v. 195, p. 1445-1454, 2002.

COOPER, M.; BURROWS, P. D. B-Cell Differentiation. Immunoglobulin Genes, p. 1, 1989.

COUTINHO, LMCC. Uso de anticorpos monoclonais na seleção de antígenos lipopolissacáride da cepa epidêmica de B:4:P1.15 de Neisseria meningitidis: Imunização intranasal. (Dissertação de Mestrado). São Paulo (SP): Faculdade de Ciências Farmacêuticas, Universidade de São Paulo, 2002.

CRAVEN, D. E.; SHEN, K. T.; FRASCH, C. E. Natural bactericidal activity of human serum against Neisseria meningitidis isolates of different serogroups and serotypes. Infect. Immun., v. 37, p. 132-137, 1982.

DAHLGREN, C.; BRIHEIM, G.; NORMAN, B.; STENDAHL, O. Deactivation of leucocyte chemotaxis in vivo. Locomotion of cells isolated from a patient with meningococcal meningitis. Scand. J. Haematol., v. 27, p. 219-223, 1981.

DANVE, B.; BRUGE, J.; BOUVERET-LE CAM, N.; CHASSARD, D.; ROUGON, G.; SCHULTZ, D. Safety and immunogenicity of an $N$-propionylated group B meningococcal polysaccharide conjugate vaccine in adult volunteers. Proceedings of the 10th International Pathogenic Neisseria Conference, p. 225, 1996.

DANVE, B.; LISSOLO, L.; MIGNON, M.; DUMAS, P.; COLOMBANI, S.; SCHRYVERS, A. B.; QUENTIN-MILLET, M. J. Transferrin-binding proteins isolated from Neisseria meningitidis elicit protective and bactericidal antibodies in laboratory animals. Vaccine, v. 11, p. 1214-1220, 1993.

DASHEFSKY, B.; TEELE, D. W.; KLEIN, J. O. Unsuspected meningococcemia. J. Pediatr., v. 102, p. 69-72, 1983.

DAVIES, R. L.; WALL, R. A.; BORRIELLO, S. P. Comparison of methods for the analysis of outer membrane antigens of Neisseria meningitides by Western blotting. J. Immunol. Methods, v. 134, p. 215-225, 1990. 
DE GASPARI, E. N. Detection of Neisseria meningitidis in cerebroespinal fluid from suspicious cases of meningococcal meningitis using polymerases chain reaction and counterimmunoelectrophoresis. Rev. Argent. Microbiol., v. 32, p. 97-103, 2000a.

DE GASPARI, E. N. Production and characterization of a new monoclonal antibody against Neisseria meningitidis; Study of the cross-reactivity with different bacterial genera. Hybridoma, v. 19, p. 445-453, 2000b.

DE KLEIJN, E. D.; DE GROOT, R.; LAFEBER, A. B.; et al. Immunogenicity and safety of monovalent $\mathrm{P} 1.7(\mathrm{~h}), 4$ meningococcal outer membrane vesicle vaccine in toddlers: comparison of two vaccination schedules and two vaccine formulations. Vaccine, v. 19, p. 1141-1148, 2000.

DE MORAES, J. C.; PERKINS, B. A.; CAMARGO, M. C. Protective efficacy of a serogroup B meningococcal vaccine in Sao Paulo, Brazil. Lancet, v. 340, p. 10741078, 1992.

DE SOUZA, V. A.; FERNANDES, S., ARAUJO, E. S.; TATENO, A. F.; OlIVEIRA, O. M.; OLIVEIRA, R. R. Use of immunoglobulin $G$ avidity test to discriminate between primary and secondary dengue vírus infections. J. Clin. Microbiol., v. 42, p. 17821784, 2004.

DEVI, S. J; SCHNEERSON, R.; EGAN, W.; VANN, W. F.; ROBBINS, J. B.; SHILOACH, J. Identity between polysaccharide antigens of Moraxella nonliquefaciens, group $B$ Neisseria meningitidis, and Escherichia coli K1 (non-O acetylated). Infect. Immun., v. 59, p. 732-736, 1991.

DEVOE, I. W.; GILCHRIST, J. E. Release of endotoxin in the form of cell wall blebs during in vitro growth of Neisseria meningitidis. J. Exp. Med., v. 138, p. 1156-1167, 1973.

DE VRIES, F. P.; VAN DER ENDE, A.; VAN PUTTEN, J. P.; DANKERT, J. Invasion of primary nasopharyngeal epithelial cells by Neisseria meningitidis is controlled by phase variation of multiple surface antigens. Infect. Immun., v. 64, p. 2998-3006, 1996.

EDWARDS, M. S.; BAKER, C. J. Complications and sequelae of meningococcal infections in children. J. Pediatr., v. 99, p. 540-545, 1981.

FARIA, S. M.; FARHAT, C. K. Bacterial meningitis - diagnosis and treatment. J. Pediatr. (Rio J.), v. 75, p. 46-56, 1999.

FIGUEROA, J. E.; DENSEN, P. Infectious diseases associated with complement deficiencies. Clin. Microbiol. Rev., v. 4, p. 359-395, 1991.

FINNE, J.; BITTER-SUERMANN, D.; GORIDIS, C.; FINNE, U. An IgG monoclonal antibody to group B meningococci cross-reacts with developmentally regulated polysialic acid units of glycoproteins in neural and extraneural tissues. $\mathbf{J}$. Immunol., v. 138, p. 4402-4407, 1987.

FISCHER, M.; PERKINS, B. A. Neisseria meningitidis serogroup B: emergence of the ET-5 complex. Semin. Pediatr. Infect. Dis., v. 8, p. 50-56, 1997. 
FRANK, M. M. Complement in the pathophysiology of human disease. N. Eng. J. Med., v. 316, p. 1525-1550, 1987.

FRASCH, C. E. Meningococcal vaccines: Past, present and future. Meningococcal Disease, p. 245-284, 1995.

FRASCH, C. E.; MCNELIS, R. M.; GOTSCHLICH, E. C. Strain-specific variation in the protein and lipopolysaccharide composition of the group B meningococcal outer membrane. J. Bacteriol., v. 127, p. 973-981, 1976.

FRASCH, C. E.; VAN ALPHEN, L.; HOLST, J.; POOLMAN, J. T.; ROSENQVIST, E. Outer membrane vesicles vaccines for meningococcal disease. Methods Mol. Med., v. 66, p. 81-107, 2001.

FRASCH, C. E.; ZOLLINGER, W. D.; POOLMAN, J. T. Serotype antigens of Neisseria meningitidis and a proposed scheme for designation of serotypes. Rev. Infect. Dis., v. 7, p. 504-510, 1985.

FREDLUND, H. Serum factors and polymorphonuclear leucocytes in human host defence against Neisseria meningitides. Studies of interactions with special reference to a chemiluminometric technique. Scandinavian Journal of Infectious diseases, v. 87, p. 1-72, 1993.

FRENCH, D. L.; LASKOV, R.; SCHARFF, M. D. The role of somatic hypermutation in the generation of antibody diversity. Science, v. 244, p. 1152-1157, 1989.

FUSCO, P. C.; MICHON, F.; TAI, J. Y.; BLAKE, M. S. Preclinical evaluation of a novel group $B$ meningococcal conjugate vaccine that elicits bactericidal activity in both mice and nonhuman primates. J. Infect. Dis., v. 175, p. 364-372, 1997.

FUKASAWA, L. O.; DIAS, W. O, SCHENKMAN R. P. F.; RAW, I. TANIZAKI, M. M. Adjuvant can improve protection induced by OMV against Neisseria meningitides serogroups B/C in neonatal mice. FEMS Immun. Med. Microb., v. 41, p. 205-210, 2004.

FUKASAWA, L. O.; GORLA, M. C. O.; LEMOS, A. P. S.; SCHENKMAN, R. P. F.; BRANDILEONE, M. C. C.; et al. Immune response to native NadA from Neisseria meningitidis and its expression in clinical isolates in Brazil. J. Med. Microbiol., v. 52, p. 121-125, 2003.

GALLICHAN, W. S.; JOHNSON, D. C.; GRAHAM, F. L.; ROSENTHAL, K. L. Mucosal immunity and protection after intranasal immunization with recombinant adenovirus expressing herpes simplex virus glycoprotein B. J. Infect. Dis., v. 168, p. 622, 1993.

GEARHART, P. J.; JOHNSON, N. D.; DOUGLAS, R.; HOOD, L. IgG antibodies to phosphorylcholine exhibit more diversity than their IgM counterparts. Nature, v. 291, p. 29-34, 1981.

GEDDE-DAHL, T. W.; HØIBY, E. A.; ESKERUD, J. R. Unbiased evidence on early treatment of suspected meningococcal disease. Rev. Infect., v. 12, p. 359, 361354, 1990. 
GIBSON, B. W.; MELAUGH, W.; PHILLIPS, M.; APICELLA, A.; CAMPAGNARI, A.; GRIFFISS, J. M. Investigation of the structural heterogecity of lipooligosaccharides from pathogenic Haemophilus and Neisseria species and of R-type lipopolysaccharides from Salmonella typhimurim by electrospray mass spectrometry. J. Bacteriol., v. 174, p. 2702-2712, 1993.

GIZURARSON, S. The relevance of nasal physiology to the design of drug absorption studies. Adv. Drug Del. Rev., v. 11, p. 329-347, 1993.

GOLD, R.; GOLDSCHNEIDER, I.; LEPOW, M. L.; DRAPER, T. E.; RANDOLPH, M. Carriage of Neisseria meningitidis and Neisseria lactamica in infants and children. J. Infect. Dis., v. 137, p. 112-121, 1978.

GOLDSCHNEIDER, I.; GOTSCHILICH, E. C.; ARTENSTEIN, M.S. Human immunity to the meningococus. The role of homoral antibodies. J. Exp. Med., v. 129, p. 13071326, 1969.

GOMEZ, J. A.; HERNANDEZ, E.; CRIADO, M. T.; FERREIROS, C. M. Effect of adjuvants in the isotypes and bactericidal activity of antibodies against the transferrin-binding proteins of Neisseria meningitidis. Vaccine, v. 16, p. 16331639, 1998.

GORRINGE, A. R. Can Neissera lactamica antigens provide an effective vaccine to prevent meningococcal disease? Expert Rev. Vaccines, v. 4, p. 373-379, 2005.

GRANOFF, D. M; BARTOLONI, A.; RICCI, S. Bactericidal monoclonal antibodies that define unique meningococcal $B$ polysaccharide epitopes that do not cross-react with human polysialic acid. J. Immunol., v. 160, p. 5028-5036, 1998.

GORRINGE, A.; HALLIWELL, D.; MATHESON, M.; REDDIN, K.; FINNEY, M.; HUDSON, M. The development of a meningococcal vaccine based on Neisseria lactamica outer membrane vesicles. Vaccine, v. 23, p. 2210-2213, 2005a.

GORRINGE, A.; OLIVER, K.; BRACEGIRDLE, P. Neisseria lactamica provides a crossreactive vaccine against meningococcal disease. Proceedings of the 12th International Pathogenic Neisseria Conference, p. 46, 2000.

GORRINGE, A. R.; REDDIN, K. M.; FUNNELL, S. G.; JOHANSSON, L.; RYTKONEN, A.; JONSSON, A. B. Experimental disease models for the assessment of meningococcal vaccines. Vaccine, v. 23, p. 2214-2217, 2005b.

GRIFFISS, J. M.; ARTENSTEIN, M. S. The ecology of the genus Neisseria. J. Med., v. 43, p. 746-761, 1976.

GRIFFISS, J. M.; BERTRAM, M. A. Immunoepidemiology of meningococcal disease in military recruits. II. Blocking of serum bactericidal activity by circulating IgA early in the course of invasive disease. J. Infect. Dis., v. 136, p. 733-739, 1977.

GRIFFISS, J. M.; BRANDT, B. L.; BROUD, D. D.; GOROFF, D, K.; BAKER, C. J. Immune response of infants and children to disseminated infections with Neisseria meningitidis. J. Infect. Dis., v. 150, p. 71-79, 1984.

GRIFFISS, J. M.; BRANDT, B.; JARVIS. G. A. Natural immunity to Neisseria meningitides. Evolution of meningococcal disease, v. 2, p. 99-119, 1987. 
GRIFFISS, J. M.; BROUD, D. D.; SILVER, C. A.; ARTENSTEIN, M. S. Immunoepidemiology of meningococcal disease in military recruits. I. A model for serogroup independency of epidemic potential as determined by serotyping. $\mathbf{J}$. Infect. Dis., v. 136, p. 176-186, 1977.

GRIFFISS, J. M.; YAMASAKI, R.; ESTABROOK, M.; KIM, J. J. Meningococcal molecular mimicry and search for an ideal vaccine. Trans. R. Soc. Trop. Med. Hyg., v. 85, p. 32-36, 1991.

HAILE, M.; SCHRODER, U.; HAMASUR, B.; PAWLOWSKI, A.; JAXMAR, T.; KALLENIUS, G.; SVENSON, S. B. Immunization with heat-killed Mycobacterium bovis bacille Calmette-Guerin (BCG) in Eurocine L3 adjuvant protects against tuberculosis. Vaccine, v. 22, p. 1498-1508, 2004.

HALSTENSEN, A.; LEHMANN, A. K.; GUTTORMSEN, H. K.; VOLLSET, S. E.; BJUNE, G.; NAESS, A. Serum opsonins to serogroup B meningococci after disease and vaccination. NIPH Ann., v. 14, p. 157-165, 1991.

HALSTENSEN, A., S.; PEDERSEN, J. H.; HANEBERG, B.; BJORVATN, B.; SOLBERG, C. O. Case fatality of meningococcal disease in western Norway. Scand. J. Infect. Dis., v. 19, p. 35-42, 1987.

HAMASUR, B.; HAILE, M.; PAWLOWSKI, A.; SCHRODER, U.; WILLIAMS, A.; HATCH, G.; HALL, G.; MARSH, P.; KALLENIUS, G.; SVENSON, S. B. Mycobacterium tuberculosis arabinomannan-protein conjugates protect against tuberculosis. Vaccine, v. 21, p. 4081-4093, 2003.

HANEBERG, B.; HERLAND BERSTAD, A. K.; HOLST, J. Bacteria-derived particles as adjuvants for non-replicating nasal vaccines. Adv. Drug. Deliv. Rev., v. 51, p. 143147, 2001.

HANEBERG, B.; TØNJUM, T.; RODAHL, K.; GEDDE DAHL, T. W. Factors preceding the onset of meningococcal disease, with special emphasis on passive smoking, stressful events, physical fitness and general symptoms of ill health. NIPH Ann., v. 6, p. 169-173, 1983.

HART, C. A., CUEVAS, L. E. Meningococcal disease in Africa. Ann. Trop. Med. Parasitol., v. 91, p. 777-785, 1997.

HAYWARD, A. R.; SIMONS, M. A.; LAWTON, A. R.; MAGE, R. G.; COOPER, M. D. Pre-B and $B$ cells in rabbits. Ontogeny and allelic exclusion of kappa light chain genes. J. Exp. Med., v. 148, p. 1367-1377, 1978.

HENSON, P. M.; HENSON, J. E.; FITTSCHEN, C.; KIMAUI, G.; BRATTON, D. C.; RICHES, W. H. Phagocytic cells: degeneration and secretion. Inflammation: basic and clinical correlates, 1988.

HERITAGE, P. L.; UNDERDOWN, B. J.; ARSENAULT, A. L.; SNIDER, D. P.; MCDERMOTT, M. R. Comparison of murine nasal-associated lymphoid tissue and Peyer's patches. Am. J. Respir. Crit. Care Med., v. 156, p. 1256, 1997. 
HIDALGO, N. T. R. Meningites - manual de instruções critérios de confirmação e classificação. Divisão de doenças de transmissão respiratória CVE, (Disponível no site: http://www.cve.saude.sp.gov.br), 2003.

HOLST, J.; FEIRING, B.; FUGLESANG, J. E. Serum bactericidal activity correlates with the vaccine efficacy of outer membrane vesicles against Neisseria meningitides serogroup B disease. Vaccine, v. 21, p. 734-737, 2003.

HUSSAIN, A.; FARAJ, J. J.; ARAMAKI, Y.; TRUELOVE, J. E. Hydrolysis of leucine enkephalin in the nasal cavity of the rat \pm a possible factor in the low bioavailability of nasally administered peptides. Biochem. Biophys. Res. Commun., v. 133, p. 923-928, 1985.

HUSSAIN, M. A.; KOVAL, C. A.; SHENVI, A. B.; AUNGST, B. J. Recovery of rat nasal mucosa from the effects of aminopeptidase inhibitors. J. Pharm. Sci., v. 79, p. 398400, 1990a.

HUSSAIN, M. A.; KOVAL, C. A.; SHENVI, A. B.; AUNGST, B. J. An aminoboronic acid derivative inhibits thymopentin metabolism by mucosal membrane aminopeptidases. Life Sci., v. 47, p. 227-231, 1990b.

HUSSAIN, M. A.; LIM, M. S.; RAGHAVAN, K. S.; ROGERS, N. J.; HIDALGO, R.; KETTNER, C. A. Aphosphinic acid dipeptide analogue to stabilize peptide drugs during their intranasal absorption. Pharm. Res., v. 9, p. 626-628, 1992.

ISON, C. A.; ANWAR, N.; COLE, M. J. Assessment of immune response to meningococcal disease: comparison of a whole-blood assay and the serum bactericidal assay. Microbiol. Pathog., v. 27, p. 207-214, 1999.

JACKSON, L. A.; TENOVER, F. C.; BAKER, C. et al. Prevalence of Neisseria meningitidis relatively resistant to penicillin in the United States 1991. J. Infect. Dis., v. 169, p. 438-441, 1994.

JACKSON, L. A.; SCHUCHAT, A.; REEVES, M. W.; WENGER, J. D. Serogroup C meningococcal outbreaks in the United States: an emerging threat. JAMA, v. 273, p. 383-389, 1995.

JACKSON, L. A.; WENGER, J. D. Laboratory-based surveillance for meningococcal disease in selected areas, United States, 1989--1991. CDC Surveillance Summaries, v. 42, p. 21-30, 1993.

JACOBS, R. F.; TABOR, D. R. The immunology of sepsis and meningitis--cytokine biology. Scand. J. Infect. Dis. Suppl., v. 73, p. 7-15, 1990.

JENNINGS, H. J.; GAMIAN, A.; ASHTON, F. E. N-propionylated group B meningococcal polysaccharide mimics a unique epitope on group B Neisseria meningitidis. J. Exp. Med., v. 165, p. 1207-1211, 1987.

JENNINGS, H. J.; ROY, R.; GAMIAN, A. Induction of meningococcal group B polysaccharide-specific IgG antibodies in mice by using an $N$-propionylated $B$ polysaccharide-tetanus toxoid conjugate vaccine. J. Immunol., v. 137, p. 17081713, 1986. 
JIANG, G.; JOSHI, S. B.; PEEK, L. J.; BRANDAU, D. T.; HUANG, J.; FERRITER, M. S.; WOODLEY, W. D.; FORD, B. M.; MAR, K. D.; MIKSZTA, J. A.; HWANG, C. R.; ULRICH, R.; HARVEY, N. G.; MIDDAUGH, C. R.; SULLIVAN, V. J. Anthrax vaccine powder formulations for nasal mucosal delivery. J. Pharm. Sci., v. 95, p. 80-96, 2005.

JOHN, C. M.; GRIFFSS, J. M.; APICELLA, M. A.; MANDRELL, R. E.; GIBSON, B. W. The structural basis for pyocin resistance in Neisseria gonorrhoeae lipooligosaccharides. J. Biol. Chem., v. 266, p. 19303-19311, 1991.

JOHNSON, K. G.; PERRY, M. B.; MCDONALD, I. J. Studies on the cellular and free lipopolysacharides from Neisseria canis and Neisseria subflava. Can. J. Microbiol., v. 22, p. 189-196, 1976.

JONES, D. M.; BORROW, R.; FOX, A. J.; GRAY, S.; CARTWRIGHT, K. A.; POOLMAN, J. T.. The lipooligosaccharide immunotype as a virulence determinant in Neisseria meningitidis. Microb. Pathog., v. 3, p. 219-224, 1992.

JONES, D. M.; ELDRIDGE, J. Development of antibodies to meningococcal protein and lipopolysaccharide serotype antigens in healthy-carriers. J. Med. Microbiol., v. 12, p. 107-111, 1979.

KALINER, M.; MAROM, Z.; PATOW, C.; SHELHAMER, J. J. Human respiratory mucus. J. Allergy Clin. Immunol., v. 73, p. 318-323, 1984.

KALLSTROM, H.; ISLAM, M. S.; BERGGREN, P. O.; JONSSON, A. B. Cell signaling by the type IV pili of pathogenic Neisseria. J. Biol. Chem., v. 273, p. 21777-21782, 1998.

KALLSTROM, H.; LISZEWSKI, M. K.; ATKINSON, J. P.; JONSSON, A. B. Membrane cofactor protein (MCP or CD46) is a cellular pilus receptor for pathogenic Neisseria. Mol. Microbiol., v. 25, p. 639-647, 1997.

KAMATH, K. R.; PARK, K. Mucosal adhesive preparations. Encyclopedia of Pharmaceutical Technology, p. 133-163, 1994.

KASPER, D. L; WINKELLHAKE, J. L.; BRANDT, B. L.; ARTENSTEIN, M.S. Antigenic specificity of bactericidal antibodies in antisera to Neisseria meningitidis. J. Infect. Dis., v. 127, p. 378-387, 1973.

KATIAL, R. K.; BRANDT, B. L.; MORAN, E. E; MARKS, S.; AGNELLO, V.; ZOLLINGER, W. D. Immunogenicity and safety testing of a group $B$ intranasal meningococcal native membrane vesicle vaccine. Infec. Immun., v. 70, p. 702-707, 2002.

KELLY, D. F.; RAPPUOLI, R. Reverse vacinology and vaccines for serogroup B Neisseria meningitides. Adv. Exp. Med. Biol., v. 568, p. 217-223, 2005.

KELSALL, B. L.; STROBER, W. Peyer's patch dendritic cells and the induction of mucosal immune responses. Res. Immunol., v. 148, p. 490-498, 1997.

KIM, J. J.; MANDRELL, R. E.; GRIFFISS, J. M. Neisseria lactamica and Neisseria meningitidis share lipooligosaccharide epitopes but lack common capsular and class 1, 2 and 3 protein epitopes. Infect. Immun., v. 57, p. 602-608, 1989. 
KIRSCH, E. A.; BARTON, R. P.; KITCHEN, L.; GIROIR, B. P. Pathophysiology, treatment and outcome of meningococcemia: a review and recent experience. Pediatr. Infect. Dis. J., v. 15, p. 967-79, 1996.

KNAPP, J. S. Historical perspectives and identification of Neisseria and related species. Clin. Microbiol. Rev., v. 1, p. 415-431, 1988.

KNIGHT, K. L.; BECKER, R. S. Molecular basis of the allelic inheritance of rabbit immunoglobulin $\mathrm{VH}$ allotypes: implications for the generation of antibody diversity. Cell., v. 60, p. 963-970, 1990.

KNIGHT, K. L.; CRANE, M. A. Generating the antibody repertoire in rabbit. Adv. Immunol., v. 56, p. 179-218, 1994.

KOCKS, C.; RAJEWSKY, K. Stable expression and somatic hypermutation of antibody $\checkmark$ regions in B-cell developmental pathways. Annu. Rev. Immunol., v. 7, p. 537559, 1989.

KUBLIK, H.; VIDGREN, M. T. Nasal delivery systems and their effect on deposition and absorption. Adv. Drug Del. Rev., v. 29, p. 157-177, 1998.

KUPER, C. F., KOORNSTRAT, P. J.; HAMELEERS, D. M. H.; BIEWENGA, J.; SPIT, B. J.; DUJIVESTJIN, A. M.; VAN BREDA VRIESMAN, P. J. C.; SMINIA, T. The role of nasopharyngeal lymphoid tissue. Immunol. Today, v. 13, p. 219, 1992.

LAEMMLI, U. K. Cleavage of structural proteins during the assembly of the head of bacteriophage T4. Nature, v. 227, p. 680-685, 1970.

LEE, C. J. Bacterial capsular polysaccharides--biochemistry, immunity and vaccine. Mol. Immunol., v. 24, p. 1005-1019, 1987.

LEE, F. K.; STEPHENS, D. S.; GIBSON, B. W.; ENGSTROM, J. J.; ZHOU D.; APICELLA, M. A. Microheterogencity of Neisseria lipooligosaccharide: analysis of a UDP-glucose 4-cpimcrase mutant of Neisseria meningitides NMB. Infect. Immun., v. 63 , p. 2508-2515, 1995.

LEHMANN, A. K.; GORRINGE, A. R.; REDDIN, K.M., WEST, K.; SMITH, I.; HALSTENSEN, A. Human opsonins induced during;meningococcal disease recognize transferrin binding protein complexes. Infect. Immun., v. 67, p. 65266532, 1999.

LEHMANN, A. K.; HALSTENSEN, A.; NAESS, A.; VOLLSET, S. E.; SJURSEN, H.; BJUNE, G. Immunisation against serogroup B meningococci: Opsonin response in vaccinees as measured by chemiluminescence. APMIS, v. 99, p. 769-772, 1991.

LELOUARD, H.; SAHUQUET, A.; REGGIO, H.; MONTCOURRIER, P. Rabbit M cells and dome enterocytes are distinct cell lineages. J. of Cell. Sci., v. 114, p. 20772083, 2001.

MAGNUSSON, C. G. Detection of anti-IgE autoantibodies. Monogr. Allergy, v. 26, p. 18-26, 1989.

MAIDEN, M. C. J.; BYGRAVES, J. A.; FEIL, E.; MORELLI, G.; RUSSELL, J. E.; URWIN, R.; ZHANG, Q.; ZHOU, J.; ZURTH, K.; CAUGANT, D. A.; FEAVERS, I. M.; ACHTMAN, M.; SPRATT, B. G. Multilocus sequence typing: a portable approach to 
the identification of clones within populations of pathogenic microorganisms. Proc. Natl. Acad. Sci. USA, v. 95, p. 3140-3145, 1998.

MAIZELS, N. Might gene conversion be the mechanism of somatic hypermutation of mammalian immunoglobulin genes? Trends Genet, v. 5, p. 4-8, 1989.

MANDRELL, R. E.; KIM, J. J.; JOHN, C. M.; GIBSON, B, W.; SUGAI, J. V.; APICELLA, M. A.; GRIFFISS, J. M.; YAMASAKI, R. Endogenous sialylation of the lipooligosaccharides of Neisseria meningitidis. J. Bacteriol., v. 173, p. 2823-2832, 1991.

MARASCO, W. A.; PHAN, S. H.; KRUTZSCH, H.; SHOWELL, H. J.; FELTNER, D. E; NAIRN, R.; BECKER, E. L.; WARD, P. A. Purification and identification of formylmethionyl-leucyl-phenylalanine as the major peptide neutrophil chemotactic factor produced by Escherichia coli. J. Biol. Chem, v. 259, p. 5430-5439, 1984.

MARIN, M. S.; MARTIN ALONSO, J. M.; PEREZ ORDOYO GARCIA LI; BOGA, J. A.; ARGUELLO-VILLARES, J. L.; CASAIS, R.; VENUGOPAL, K.; JIANG, W.; GOULD, E. A.; PARRA, F. Immunogenic properties of rabbit haemorrhagic disease virus structural protein VP60 expressed by a recombinant baculovirus: an efficient vaccine. Virus Res., v. 39, p. 119-128, 1995.

MAROM, Z.; SHELHAMER, J.; KALINER, M. Nasal mucus secretion. Ear Nose Throat J., v. 63, p. 36-44, 1984.

MASLANKA, S. E.; GHEESLING, L. L.; LIBUTTI, D. E.; DONALDSON, K. B.; HARAKEH, H. S.; DYKES, J. K.; ARHIN, F. F.; DEVI, S. J.; FRASCH, C. E.; HUANG, J. C.; KRIZ-KUZEMENSKA, P.; LEMMON, R. D.; LORANGE, M.; PEETERS, C. C.; QUATAERT, S.; TAI, J. Y.; CARLONE, G. M. Standardization and a multilaboratory comparison of Neisseria meningitidis serogroup $A$ and $C$ serum bactericidal assays. Clin. Diagn. Lab. Immunol., v. 4, p. 156-167, 1997.

MCELROY, P. J.; WILLCOX, N.; CATTY, D. Early precursors of B lymphocytes. I. Rabbit/mouse species differences in the physical properties and surface phenotype of pre-B cells, and in the maturation sequence of early B cells. Eur. J. Immunol., v. 11, p. 76-85, 1981.

MEYER, T. F.; POHMER, J.; VAN PUTTEN, J. P. Biology of the pathogenic Neisseriae. Curr. Top. Microb. Immunol. Berlin, v. 192, p. 283-316, 1994.

MEYNELL, H.; THOMAS, N. W.; JAMES, P. S.; HOLLAND, J.; TAUSSING, M. J.; NICOLETTI, C. Up-regulation of microsphere transport across the follicleassociated epithelium of Peyer's patch by exposure to Streptococcus pneumoniae R. 36a. FASEB J., v. 13, p. 611-619, 1999.

MICHAELSEN, T. E.; AASE, A.; KOLBERG, J.; WEDGE, E.; ROSENQVIST, E. PorB3 outer membrane protein on Neisseria meningitidis is poorly accessible for antibody binding on live bacteria. Vaccine, v. 19, p. 1526-1533, 2001.

MIKSZTA, J. A.; SULLIVAN, V. J.; DEAN, C.; WATERSTON, A. M.; ALARCON, J. B.; DEKKER, J. P. III; BRITTINGHAM, J. M.; HUANG, J.; HWANG, C. R.; FERRITER, M.; JIANG, G.; MAR, K.; SAIKH, K. U.; STILES, B. G.; ROY, C. J.; ULRICH, R. G.; 
HARVEY, N. G. Protective immunization against inhalational anthrax: a comparison of minimally invasive delivery platforms. J Infect Dis., v. 191, p. 278-288, 2005.

MILAGRES, L. G.; RAMOS, S. R.; SACCHI, C. T.; et al. Immune response of Brazilian children to a Neisseria meningitidis serogroup $B$ outer membrane protein vaccine: comparison with efficacy. Infect. Immun., v. 62, p. 4419-4424, 1994.

MORAN, E. E.; BRANDT, B. L.; ZOLLINGER, W. D. Expression of the L8 lipopolyssacharide determinant icrease the sensitivity of Neisseria meningitides to serum bactericidal activity. Infect. Immun. Washington, v. 62, p. 5290-5295, 1994.

MORIN, M. J.; WARNER, A.; FIELDS, B. N. A pathway for entry of retroviruses into the host through $\mathrm{M}$ cells of the respiratory tract. J. Exp. Med., v. 180, p. 1523-1527, 1994.

MORLEY, S. L.; POLLARD, A. J. Vaccine prevention of meningococcal disease, coming soon? Vaccine, v. 20, p. 666-687, 2001.

MULKS, M. H.; PLAUT, A. G. IgA protease production as a characteristic distinguishing pathogenic from harmless Neisseriaceae. N. Engl. J. Med., v. 299, p. 973-976, 1978.

NARITA, M.; MATSUZONO, Y.; TAKEKOSHI, Y.; YAMADA, S.; ITAKURA, O.; KUBOTA, M. Analysis of mumps vaccine failure by means of avidity testing for mumps vírus-specific immunoglobulin G. Clin. Diagn. Lab. Immunol., v. 5, p. 799803, 1998.

NASSIF, X. Gonococcal lipooligosaccharide: an adhesin for bacterial dissemination? Trends Microbiol., v. 8, p. 539-540, 2000.

NASSIF, X. Interaction mechanisms of encapsulated meningococci with eucaryotic cells: what does this tell us about the crossing of the blood-brain barrier by Neisseria meningitidis? Curr. Opin. Microbiol., v. 2, p. 71-77, 1999.

NASSIF, X.; SO, M. Interaction of pathogenic neisseriae with nonphagocytic cells. Clin. Microbiol., v. 8, p. 376-388, 1995.

NATARO, J.; LEVINE, M. M. Enteric bacterial vaccines: Salmonella, Shigella, cholera, Escherichia coli. Mucosal Immunology, p. 851 - 866, 1999

NÉRI S. V, CARMO A.M. S., TUNES, C. F., FERRAZ A. S, THOMAZ BELO E. F, COUTINHO LMCC, ITO, A. Y, DE GASPARI E. N. Immune response of neonatal mice priming with heat inactivated Neisseria lactamica, Rev. Inst. Adolfo Lutz, v. 62, p. 50, 2003.

NEUTRA, M. R.; KRAEHENBUHL, J. P. M cells as a pathway for antigen update and processing. Essentials of mucosal immunology, p. 29-36, 1996.

NIKLASSON, P. M.; LUNDBERGH, P.; STRANDELL, T. Prognostic factors in meningococcal disease. Scand. J. Infect. Dis., v. 3, p. 17-25, 1971.

NORONHA, C. P.; STRUCHINER, C. J.; HALLORAN, M. E. Assessment of the direct effectiveness of $B C$ meningococcal vaccine in Rio de Janeiro, Brazil: a case-control study. Int. J. Epidemiol, v. 24, p. 1050-1057, 1995. 
O'DWYER, C. A.; REDDIN, K.; MARTIN, D. Expression of heterologous antigens in commensal Neisseria spp.: preservation of conformational epitopes with vaccine potential. Infect. Immun., v. 72, p. 6511-6518, 2004.

OFEK, I.; SHARON, N. Lectinophagocytosis: a molecular mechanism of recognition between cell surface sugars and lectins in the phagocytosis of bacteria. Infect. Immun., v. 56, p. 539-547, 1988.

OGRA, P. L. Mucosal immunoprophylaxis: An introductory Overview. Musocal Vaccines, p. 3-13, 1996.

OGRA, P. L.; FADEN, H.; WELLIVER, R. C. Vaccination strategies for mucosal immune responses. Clin. Microbiol. Rev., v. 14, p. 430-445, 2001.

OLCÉN, P.; KJELLANDER, J.; DANIELSSON, D.; LINDQUIST, B. L. Epidemiology of Neisseria meningitidis: prevalence and symptoms from the upper respiratory tract in family members to patients with meningococcal disease. Scand. J. Infect. Dis., v. 13, p. $105-109,1981$.

OLIVER, K. J.; REDDIN, K. M.; BRACEGIRDLE, P.; HUDSON, M. J.; BORROW, R.; FEAVERS, I. M.; et al. Neisseria lactamica protects against experimental meningococcal infection. Infect. Immunol., v. 70, p. 3621-3626, 2002.

OSMOND, D. G. B cell development in the bone marrow. Semin. Immunol., v. 2, p. 173-180, 1990.

PARSONS, N. J.; ANDRADE, J. R. C.; PATEL, P.V.; COLE, J. A.; SMITH, H. Sialylation of lipopolysaccharide and loss of absorption of bactericidal antibody during conversion of gonococci to scrum resistance by cytidinc 5'-monophosphate-Nacetyl neuraminic acid. Microb. Pathog., v. 7, p. 63-72, 1989.

PAVLIAK, V.; BRISSON, J. R.; MICHON, F.; UHRIN, D.; JENNINGS, H. J. Structure of the sialylated L3 lipopolysaccharide of Neisseria meningitides. J. Biol. Chem., v. 268, p. 14146-14152, 1993.

PAVLIAK, V.; FORTUNA-NEVIN, M.; MONTEIRO, M.; MASON, K.; ZHU, D. Neisseria meningitidis LOS conjugate vaccine against meningococcal disease. 14th International Pathogenic Neisseria Conference, 2004.

PELTOLA, H. Meningococcal vaccines: current status and future possibilities. Drugs, v. 55, p. 347-356, 1998.

PELTOLA, H. Meningococcal disease: still with us. Rev. Infect. Dis., v. 5, p. 71-91, 1983.

PETTERSSON, A.; PRINZ, T.; UMAR, A.; VAN DER BIEZEN, J.; TOMMASSEN, J. Molecular characterization of $\mathrm{LbpB}$, the second lactoferrin-binding protein of Neisseria meningitidis. Mol. Microbiol., v. 27, p. 599-610, 1998.

PINK, J. R. L.; LASSILA, O.; VAINIO, O. B-lymphocytes and their self renewal. Avian Immunology: Basis and Practice, p. 65, 1986.

PINTOR, M., GÓMEZ, J. A.; FERRÓN, L.; FERREIRÓS, C. M.; CRIADO, M. T. Análisis of TbpA and TbpB functionality in defective mutants of Neisseria meningitidis. $\mathbf{J}$. Med. Microbiol., v. 47, p. 757-760, 1998. 
PLATONOV, A. E.; VERSHININA, I. V.; KUIJPER, E. J.; BORROW, R.; KAYHTY, H. Long term effects of vaccination of patients deficient in a late complement component with a tetravalent meningococcal polysaccharide vaccine. Vaccine, $v$. 21, p. 4437-4447, 2003.

PLESTED, J. S.; HARRIS, S. L.; WRIGHT, J. C. Highly conserved Neisseria meningitides inner-core lipopolysaccharide epitope confers protection against experimental meningococcal bacteremia. J. Infect. Dis., v. 187, p. 1223-1234, 2003.

PLESTED, J. S.; MAKEPEACE, K.; JENNINGS, M. P.; et al. Conservation and accessibility of an inner core lipopolysaccharide epitope of Neisseria meningitidis. Infect. Immun., v. 67, p. 5417-5426, 1999.

POLLARD, A. J.; FRASCH, C. Development of natural immunity to Neisseria meningitides. Vaccine, v. 19, p. 1327-1346, 2001.

POLLARD, A. J., LEVIN, M. Production of low-avidity antibody by infants after infection with serogroup B meningococci. Lancet, v. 356, p. 2065-2066, 2000.

POLLARD, A. J.; MEHTA, N.; COEN, P. Reduction in mortality from invasive meningococcal disease in the intensive care unit: development of an emergency treatment algorithm. Proceedings of the 12th Pathogenic Neisseria Conference, p. 101, 2000.

POOLMAN, J. T. Development of a meningococcal vaccine. Infect. Agents. Dis., v. 4, p.13-28, 1995.

POOLMAN, J.; BERTHET, F. X. Alternative vaccine strategies to prevent serogroup B meningococcal diseases. Vaccine, v. 20, p. 24-26, 2001.

POOLMAN, J. T.; HOPMAN, C. T. P.; ZANEM, H. C. Problems in the definition of meningococcal serotypes. FEMS Microbiol. Lett., v. 19, p. 339-348, 1982.

PORGADOR, A.; STAATS, H. F.; FAIOLA, B.; GILOBA, E.; PALKER, T. J. Intranasal immunization with CTL epitope peptides of HIV-1 or ovalbumin with the mucosal adjuvant cholera toxin induces specific CTL and protection against tumor development in vivo. J. Immunol., v. 158, p. 834, 1997.

QUAGLIARELLO, V.; SCHELD, W. M. Bacterial meningitis: pathogenesis, pathophysiology, and progress. N. Engl. J .Med., v. 327, p. 864-872, 1992.

RAPHAEL, J. H.; SELWYN, D. A.; MOTTRAM, S. D.; LANGTON, J. A.; O'CALLAGHAN, C. Effects of 3MAChalothane, enflurane and isoflurane on cilia beat frequency of human nasal epithelium in vitro. Br. J. Anaesth., v. 76, p. 116-121, 1996a.

RAPHAEL, J. H.; STRUPISH, J.; SELWYN, D. A.; HANN, H. C. L.; LANGTON, J. A. Recovery of respiratory ciliary function after depression by inhalation anaesthetic agents: an in vitro study using nasal turbinate explants. Br. J. Anaesth., v. 76, p. 854-859, 1996b.

RAPPUOLI, R.; MILLER, H. I.; FALKOW, S. Medicine. The Intangible Value of Vaccination Science. Science, v. 297, p. 937-939, 2002. 
RAYNER, C. F.; DEWAR, A.; MOXON, E. R.; VIRJI, M.; WILSON, R. The effect of variations in the expression of pili on the interaction of Neisseria meningitidis with human nasopharyngeal epithelium. J. Infect. Dis., v. 171, p. 113-121, 1995.

RAZA, M. W.; EL AHMER, O. R.; OGILVIE, M. M.; BLACKWELL, C. C.; SAADI, A. T.; ELTON, R. A.; WEIR, D. M. Infection with respiratory syncytial virus enhances expression of native receptors for non-pilate Neisseria meningitidis on HEp-2 cells. FEMS Immunol. Med. Microbiol., v. 23, p. 115-124, 1999.

REQUEJO, H. I. Z. Neisseria meningitidis: Análise dos antígenos de membrana externa e distribuição geográfica dos sorotipos e subtipos. Laes \& Haes, v. 103, p. 98-120, 1996.

REYNAUD, C. A.; ANQUEZ, V.; DAHAN, A.; WEILL, J. C.; A single rearrangement event generates most of the chicken immunoglobulin light chain diversity. Cell, $v$. 40, p. 283-291, 1985.

REYNAUD, C. A.; ANQUEZ, V.; GRIMAL, H.; WEILL, J. C. A hyperconversion mechanism generates the chicken light chain preimmune repertoire. Cell, v. 48, p. 379-388, 1987.

ROBBINS, J. B.; MYEROWITZ, L.; WHISNANT, J. K.; ARGAMAN, M.; SCHNEERSON, R.; HANDZEL, Z. T.; GOTSCHLICH, E. C. Enteric bacteria cross-reactive with Neisseria meningitidis groups $A$ and $C$ and Diplococcus pneumoniae types I and 3. Infect. Immun., v. 6, p. 651-656, 1972.

RODRIGUEZ, A. P.; DICKINSON, F.; BALY, A.; MARTINEZ, R. The epidemiological impact of antimeningococcal B vaccination in Cuba. Mem. Inst. Oswaldo Cruz, v. 94, p. 433-440, 1999.

ROITT, T.; BROSTOFF, J.; MALE, D. O Sistema Linfóide das Mucosas. Immunología, cap. 3, p. 36-37, 1999.

ROSENSTEIN, N. E.; PERKINS, B. A.; STEPHENS, D. S.; LEFKOWITZ, L.; CARTTER, M. L.; DANILA, R.; CIESLAK, P.; SHUTT, K. A.; POPOVIC, T.; SCHUCHAT, A.; HARRISON, L. H.; REINGOLD, A. L. The changing epidemiology of meningococcal disease in the United States, 1992-1996. J. Infect. Dis., v. 180, p. 1894-1901, 1999.

ROSENSTEIN, N. E.; PERKINS, B. A.; STEPHENS, D. S.; POPOVIC, T.; HUGHES, J. M. Meningococcal disease. N. Engl. J. Med., v. 344, p. 1378-1388, 2001.

ROSENSTEIN, N. E.; STOCKER, S. A.; POPOVIC, T.; TENOVER, F. C.; PERKINS, B. A. Active Bacterial Core Surveillance Team. Antimicrobial resistance of Neisseria meningitidis in the United States, 1997. Clin. Infect. Dis., v. 30, p. 212-213, 2000.

RUDEL, T.; SCHMID, A.; BENZ, R.; KOLB, H. A.; LANG, F.; MEYER, T. F. Modulation of Neisseria porin (PorB) by cytosolic ATP/GTP of target cells: parallels between pathogen accommodation and mitochondrial endosymbiosis. Cell., v. 85, p. 391402, 1996.

SACCHI, C. T.; DE LEMOS, A. P.; CAMARGO, M. C.; WHITNEY, A. M.; MELLES, C. E.; SOLARI, C. A.; FRASCH, C. E.; MAYER, L. W. Meningococcal disease caused 
by Neisseria meningitidis serogroup B serotype in São Paulo, Brazil, 1990 to 1996. Rev. Inst. med. Trop., v. 40, p. 65-70, 1998.

SALIH, M. A.; AHMED, H. S.; OSMAN, K. A.; KAMIL, I.; PALMGREN, H.; HOFVANDER, Y.; OLCEN, P. Clinical features and complications of epidemic group $A$ meningococcal disease in Sudanese children. Ann. Trop. Paediatr., v. 10, p. 231238, 1990.

SANCHEZ, S.; TRONCOSO, G.; CRIADO, M. T.; FERREIRÓS, C. In vitro induction of memory-driven responses against Neisseria meningitidis by priming with Neisseria lactamica. Vaccine, v. 20, p. 2957-2963, 2002a.

SANCHEZ, S.; TRONCOSO, G.; CRIADO, M. T.; FERREIRÓS, C. Interespecific neisserial high molecular weight proteins able induce natural immunity responses are strongly correlated with in vitro bactericidal activity. Vaccine, v. 20, p. 29642967, 2002b.

SANSONETTI, P. J.; ARONDEL, J.; CANTEY, J. R.; PREVOST, M. C.; HUERRE, M. Infection of rabbit Peyer's patches by Shigella flexneri: effect of adhesive or invasive bacterial phenotypes on follicle-associated epithelium. Infect. Immun., v. 64, p. 2752-2764, 1996.

SAVIDGE, T. C.; SMITH, M.; JAMES, P. S.; ALDRED, P. Salmonella-induced M-cell formation in germ-free mouse Peyer's patch tissue. Am. Pathol., v. 139, p. 177184, 1991.

SARDINAS, G.; REDDIN, K.; PAJON, R.; GORRINGE, A. Outer membrana vesicles of Neisseria lactamica as a potential mucosal adjuvant. Vaccine, 2005.

SAUNDERS, N. B.; SHOEMAKER, D. R.; ZOLLINGER, W. D.; BRANDT, B. L., MORAN, E. E.; RARSEN, T. Immunogenicity of intranasally administered meningococcal native outer membrane vesicle in mice. Infect. Immun., v. 67, p. 113-119, 1999.

SENEME, F. A. Avaliação da resposta imune em coelhos pela via de imunização nasal com antígenos de Neisseria meningitidis B selecionados para os

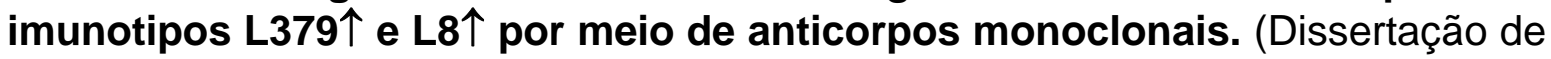
Mestrado). São Paulo (SP): Secretaria de Estado da Saúde, 2005.

SHAPIRO, E. D.; Aaron, N. H.; Wald, E. R.; Chiponis, D. Risk factors for development of bacterial meningitis among children with occult bacteremia. J. Pediatr., v. 109, p. 15-19, 1986.

SIERRA, G. V.; CAMPA, H. C.; VARCACEL, N. M.; et al. Vaccine against group B Neisseria Meningitidis: protection trial and mass vaccination results in Cuba. NIPH Ann. Dis., v. 14, p. 195-210, 1991.

SINCLAIR, J. F.; SKEOCH, C. H.; HALLWORTH, D. Prognosis of meningococcal septicaemia. Lancet, v. 2, p. 38, 1987.

SOENAWAN, E.; SRIVASTAVA, I.; GUPTA, S.; KAN, E.; JANANI, R.; KAZZAZ, J.; SINGH, M.; SHREEDHAR, V.; VAJDY, M. Maintenance of long-term immunological 
memory by low avidity IgM-secreting cells in bone marrow after mucosal immunizations with cholera toxin adjuvant. Vaccine, v. 22, p. 1553-1563, 2004.

SOANE, R. J.; FRIER, M.; PERKINS, A. C.; JONES, N. S.; DAVIS, S. S.; ILLUM, L. Evaluation of the clearance of bioadhesive systems in humans. Int. J. Pharm., v. 178, p. 55-65, 1999.

STAATS, H. F.; JACKSON, R. J.; MARINARO, M.; TAKAHASHI, I.; KIYONO, H.; MCGHEE, J. R. Mucosal immunity to infection with implications for vaccine development. Curr. Opin. Immunol., v. 6, p. 572-583, 1994.

STEEGHS, L.; KUIPERS, B.; HAMSTRA, H. J.; KERSTEN, G.; VAN ALPHEN, L.; VAN DER LEY, P. Immunogenicity of outer membrane proteins in a lipopolysaccharidedeficient mutant of Neisseria meningitidis: influence of adjuvants on the immune response. Infect. Immun., v. 67, p. 4988-4993, 1999.

STEPHENS, D. S.; EDWARDS, K. M.; MORRIS, F.; MCGEE, Z. A. Pili and outer membrane appendages on Neisseria meningitidis in the cerebrospinal fluid of an infant. J. Infect. Dis., v. 146, p. 568, 1982.

STEPHENS, D. S.; FARLEY, M. M. Pathogenic events during infection of the human nasopharynx with Neisseria meningitidis and Haemophilus influenzae. Ver. Infect. Dis., v. 13, p. 22-33, 1991.

STEPHENS, D. S.; WHITNEY, A. M.; MELLY, M. A.; HOFFMAN, L. H.; FARLEY, M. M.; FRASCH, C. E. Analysis of damage to human ciliated nasopharyngeal epithelium by Neisseria meningitidis. Infect. Immun., v. 51, p. 579-585, 1986.

STIEHM, E. R.; DAMROSCH, D. S. Factors in the prognosis of meningococcal infection. Review of 63 cases with emphasis on recognition and management of the severely ill patient. J. Pediatr., v. 68, p. 457-467, 1966.

STRATFORD, R. E.; LEE, V. H. L. Aminopeptidase activity in homogenates of various absorptive mucosae in the albino rabbit: implications in peptide delivery. Int. J. Pharm., v. 30, p. 73-82, 1986.

STUART, J. M.; CARTWRIGHT, K. A.; JONES, D. M.; NOAH, N. D.; WALL, R. J.; BLACKWELL, C. C.; JEPHCOTT, A. E.; FERGUSON, I. R. An outbreak of meningococcal disease in Stonehouse: planning and execution of a large-scale survey. Epidemiol. Infect., v. 99, p. 579-589, 1987.

SUCKOW, M. A.; BOWERSOCK, T. L.; NIELSEN, K.; CHRISP, C. E.; FRANDSEN, P.L.; JANOVITZ, E. B. Protective immunity to Pasteurella multocida heat-labile toxin by intranasal immunization in rabbits. Lab. Anim. Sci., v. 45, p. 526-532, 1995.

SUCKOW, M. A.; BOWERSOCK, T. L.; NIELSEN, K.; GRIGDESBY, C. F. Enhancement of respiratory immunity to Pasteurella multocida by cholera toxin in rabbits. Lab. Anim., v. 30, p. 120-126, 1996.

SUCKOW, M. A.; JARVINEN, L. Z.; HOGENESCH, H.; PARK, K.; BOWERSOCK, T. L. Immunization of rabbits against a bacterial pathogen with an alginate microparticle vaccine. J. Control Release, v. 85, p. 227-235, 2002. 
SULLIVAN, T. D.; LASCOLEA, L. J. Jr. Neisseria meningitidis bacteremia in children: quantitation of bacteremia and spontaneous clinical recovery without antibiotic therapy. Pediatrics, v. 80, p. 63-67, 1987.

SUN, Y.; BAKSHI, S.; CHALMERS, R.; TANG, C. Functional genomics of Neisseria meningitidis pathogenesis. Nat. Med., v. 6, p. 1269-1273, 2000.

TANG, C.; MOXON, R.; LEVINE, M. For discussion: Live attenuated vaccines for group B meningococcus. Vaccine, v. 17, p. 114-117, 1999.

TETTELIN, H.; SAUNDERS, N.; HEILDEBERG, J.; JEFFRIES, A.; NELSON, K.; ELSEN, J., et al. Complete genome sequence of Neisseria meningitidis serogroup B strain MC58. Science, v. 287, p. 1809-1815, 2000.

THAETE, L. G.; SPICER, G. S.; SPOCK, A. Histology, ultrastructure and carbohydrate cytochemistry of surface and glandular epithelium of human nasal mucosa. Am. J. Anat., v. 162, p. 243-263, 1981.

TONDELLA, M. L.; POPOVIC, T.; ROSENSTEIN, N. E. Distribuition Of Neisseria meningitides serogroup $B$ serosubtypes and serotypes circulating in the United States. The Active Bacterial Core Surveillance Team. J. Clin. Microbiol., v. 38, p. 3323-3328, 2000.

TOWBIN, H.; STAEHELIN, T.; GORDON, J. Electrophoretic transfer of proteins from polyacrylamide gels to nitrocellulose sheets: procedure and some applications. Proc. Natl. Acad. Sci., v. 76, p. 4350-4354, 1979.

TRAMONT, E. C.; SADOFF, J. C.; ARTENSTEIN, M. S. Cross-reactivity of Neisseria gonorrhoeae and Neisseria meningitidis and the nature of antigens involved in the bactericidal reaction. J. Infect. Dis., v. 130, p. 240-247, 1974.

TSAI, S.Y.; TSAI, M. J.; KOPS, L. E.; MINGHETTI, P.P.; O'MALLEY, B. W. Transcription factors from oviduct and HeLa cells are similar. J. Biol. Chem., v. 256, p. 1305513059, 1981.

TUNES, C. F., DE GASPARI E. N. Antigenic cross reactivity between proteins of meningococcos and commensal Neisseria species using normal and convalescent sera of patients infected with Neisseria meningitidis B. XXVII Meeting of the Brazilian Society of Immunology - V International Symposium on allergy and clinical immunology, 2002.

TUNES, C. F., DE GASPARI E. N. Immunogenicity of intranasally administered meningococcal native outer membrane vesicles: study of the cross reactivity with Neisseria lactamica strains. XXVII Meeting of the Brasilian Society of Immunology - V International Symposium on Allergy and Clinical Immunology, 2002.

TUNES, C. F., THOMAZ BELO E. F, COUTINHO LMCC, FERRAZ A. S, CARMO A.M. S., ITO, A. Y, NERI S. V, DE GASPARI E. N. Intranasal priming with Neisseria lactamica for the induction of a systemic immune response against Neisseria meningitides. Rev. Inst. Adolfo Lutz., v. 62, p. 50, 2003. 
TZENG, Y. L.; STEPHENS, D. S. Epidemiology and pathogenesis of Neisseria meningitides. Microbes and Infection, v. 2, p. 687-700, 2000.

UGWOKE, I. M.; VERBEKE, N.; KINGET, R. The biopharmaceutical aspects of nasal mucoadhesive drug delivery. J. of Pharmacy and Pharmacology, v. 53, p. 3-22, 2001.

URWIN, R.; RUSSEL, J. E.; THOMPSONS, E. A.; HOLMES, E. C. FEAVERS, IM M. MAIDEN, M. C. Distribution of surface protein variants among hyperinvasive meningococci: implications for vaccine design. Infec. Immun., v. 72, p. 5955-5962, 2004.

USINGER, W. R.; LUCAS, A. H. Avidity as a determinant of the protective efficacy of human antibodies to pneumococcal capsular polysaccharides. Infect. Immun., v. 67, p. 2366-2370, 1999.

VAN DER LEY, P.; POOLMAN, J. T. Construction of a multivalent meningococcal vaccine strain based on the class 1 outer membrane protein. Infect. Immun., v. 60, p. 3156-3161, 1992.

VAN DEUREN, M.; SANTMAN, F. W.; VAN DALEN, R.; SAUERWEIN, R. W.; SPAN, L. F.; VAN DER MEER, J. W. Plasma and whole blood exchange in meningococcal sepsis. Clin. Infect. Dis., v. 15, p. 424-430, 1992.

VARAINE, F.; CAUGANT, D. A.; RIOU, J. Y.; KONDE, M. K.; SOGA, G.; NSHIMIRIMANA, D.; MUHIRWA, G.; OTT, D.; HOIBY, E. A.; FERMON, F.; MOREN, A. Meningitis outbreaks and vaccination strategy. Trans. R. Soc. Trop. Méd. Hyg., v. 91, p. 3-7, 1997.

VAUGHAN, T. E.; HUDSON, M. J.; SKIPP, P. J.; GORRINGE, A. R. Proteomic analysis of Neisseria meningitides and Neisseria lactamica outer membrane vesicle vaccines. $14^{\text {th }}$ International Pathogenic Neisseria Conference, 2004.

VAZQUEZ, J. A. El desarrollo de vacunas frente a meningococo: Un largo, tortuoso y aún inacabado camino. Enferm. Infecc. Microbiol. Clin., v. 20, p. 316-320, 2002.

VEDROS, N. A. Development of Meningococcal Serotyping. Evolution of Meningococcal disease, v. 3, cap. 5, p. $39-53,1989$.

VEDROS, N. A. Genus I Neisseria. Bergey's Manual of Systematic Bacteriology, v. 1, p. 290-296, 1984.

VELIN, D.; FOTOPOPULOS, G.; LUTHI, F.; KRAEHENBUHL, J. P. The nasalassociated lymphoid tissue of adult mice acts as an entry site for the mouse mammary tumor retrovirus. J. Exp. Med., v. 185, p. 1871, 1997.

VERHEUL, A. F. M.; SNIPPE, H.; POOLMAN, J. T. Meningococcal lipopolyssacharides: virulence factor and potential vaccine component. Microbiol. Rev., v. 57, p. 34-39, 1993.

VERMONT, C. L.; VAN DEN DOBBELSTEEN, G. P. Meningococcal serogroup B infections: a search for a broadly protective vaccine. Expert. Rev. Vaccines., v. 2, p. 673-681, 2003. 
VERMONT, C. L.; VAN DIJKEN, H. H.; VAN LIMPT, C. J.; DE GROOT, R.; VAN ALPHEN, L.; VAN DEN DOBBELSTEEN, G. P. Antibody avidity and immunoglobulin $G$ isotype distribution following immunization with a monovalent meningococcal B outer membrane vesicle vaccine. Infect. Immun., v. 70, p. 584590, 2002.

VIDARSON, G.; POL, W. L.; VAN DER ELSEN, J. M. H.; VILÉ, H.; JANSEN, M.; RUJIS, J.; MORTON, H. C.; BOEL, E.; DAHA, M. R; CORTHESY, B.; DER WINKEL, J. G. L. Activity of human IgG and IgA subclasses in immune defense against Neisseria meningitidis serogroup. B. J. Immunol., v. 166, p. 6251-6252, 2001.

VIRJI, M.; ALEXANDRESCU, C.; FERGUSON, D. J.; SAUNDERS, J. R.; MOXON, E. R. Variations in the expression of pili: the effect on adherence of Neisseria meningitidis to human epithelial and endothelial cells. Mol. Microbiol., v. 6, p. 1271-1279, 1992.

VIRJI, M.; MAKEPEACE, K.; PEAK, I. R.; FERGUSON, D. J.; JENNINGS, M. P.; MOXON, E. R. Opc- and pilus-dependent interactions of meningococci with human endothelial cells: molecular mechanisms and modulation by surface polysaccharides. Mol. Microbiol., v. 18, p. 741-754, 1995.

VIRJI, M.; WATT, S. M.; BARKER, S.; MAKEPEACE, K.; DOYONNAS, R. The Ndomain of the human CD66a adhesion molecule is a target for Opa proteins of Neisseria meningitidis and Neisseria gonorrhoeae. Mol. Microbiol., v. 22, p. 929939, 1996.

VITOVSKI, S.; READ, R. C.; SAYERS, J. R. Invasive isolates of Neisseria meningitidis possess enhanced immunoglobulin A1 protease activity compared to colonizing strains. FASEB J, v. 13, p. 331-337, 1999.

WAAGE, A.; AASEN, A. O. Different role of cytokine mediators in septic shock related to meningococcal disease and surgery/polytrauma. Immunol. Rev., v. 127, p. 221230, 1992.

WAAGE, A.; BRANDTZAEG, P.; HALSTENSEN, A.; KIERULF, P.; ESPEVIK, T. The complex pattern of cytokines in serum from patients with meningococcal septic shock. Association between interleukin 6, interleukin 1, and fatal outcome. J. Exp. Med., v. 169, p. 333-338, 1989.

WAAGE, A.; HALSTENSEN, A.; ESPEVIK, T. Association between tumour necrosis factor in serum and fatal outcome in patients with meningococcal disease. Lancet, v. 1, p. 355-357, 1987.

WAAGE, A.; HALSTENSEN, A.; SHALABY, R.; BRANDTZAEG, P.; KIERULF, P.; ESPEVIK, T. Local production of tumor necrosis factor alpha, interleukin 1, and interleukin 6 in meningococcal meningitis. Relation to the inflammatory response.

J. Exp. Med., v. 170, p. 1859-1867, 1989.

WANG, L. Y.; FRASCH, C. E. Development of a Neisseria meningitides group B serotype $2 \mathrm{~b}$ protein vaccine and evaluation in a mouse model. Infect. Immun., v. 46, p. 408-14, 1984. 
WEDEGE, E.; HOIBY, E. A.; ROSENQVIST, E.; BJUNE, G. Immune responses against major outer membrane antigens of Neisseria meningitides in vaccinees and controls who contracted meningococcal disease during the Norwegian serogroup $B$ protection trial. Infect. Immun., v. 66, p. 3223-3231, 1998.

WU, H. Y.; NGUYEN, H. H.; RUSSELL, M. W. Nasal lymphoid tissue (NALT) as a mucosal inductive site. Scand. J. Immunol., v. 46, p. 506, 1997.

WU, H.Y.; NIKOLOVA, E. B.; BEAGLEY, K. W.; RUSSELL, M. W. Induction of antibodysecreting cells and T-helper and memory cells in murine nasal lymphoid tissue. Immunology, v. 88, p. 493, 1996.

WYSOCKI, L. J.; GEFTER, M. L. Gene conversion and the generation of antibody diversity. Annu. Rev. Biochem., v. 58, p. 509-531, 1989.

ZOLLINGER, W.D.; MANDRELL, R. E.; GRIFFSS, J. M.; ALTIERI, P.; BERMAN, S. Complex of meningococcal group $B$ polysaccharide and type 2 outer membrane protein immunogenic in man. J. Clin. Invest, v. 63, p. 836-848, 1979.

ZOLLINGER, W. D.; MORAN, E. E. Meningococcal vaccines: present and future. Trans. R. Soc. Trop. Med. Hyg., v. 85, p. 37-43, 1991a.

ZOLLINGER, W. D.; MORAN, E. E.; DEVI, S. J.; FRASCH, C. E. Bactericidal antibody responses of juvenile rhesus monkeys immunized with group B Neisseria meningitidis capsular polysaccharide-protein conjugate vaccines. Infect. Immun., v. 65, p. 1053-1060, 1997.

ZUERCHER, A. W.; COFFIN, S. E.; THURNHEER' M.C.; FUNDOVA, P.; CEBRA, J. J.; Nasal-Associated Lymphoid Tissue Is a Mucosal Inductive Site for Virus-Specific Humoral and Cellular Immune Responses. The Journal of Immunology, v. 168, p. 1796-1803, 2002a.

ZUERCHER, A. W.; HAN-QING, J.; THURNHEER' M.C.; CHRISTOPHER, F. C.; CEBRA, J. J. Distinct Mechanisms for Cross-Protection of the Upper Versus Lower Respiratory Tract Through Intestinal Priming. The Journal of Immunology, v. 169, p. 3920-3925, 2002b. 


\section{VIII - ANEXOS}

\section{Reagentes e Soluções}

Acetato de sódio a $0,2 \mathrm{M}$

Acido acético glacial a 7\%.

AEC: $(2,6 \mathrm{~mL}$ AEC a 4\% + 40mL de solução de acetato de sódio, pH 5,0)

Agar base "Müeller-Hinton" com 1\% de soro de cavalo

Agar-chocolate, em base Müeller-Hinton,

Agar-soro preparado com base ágar soja e trypticaseina

Brometo de cianogênio

Caldo "Müeller-Hinton"

EDTA $1 \mathrm{mM}$

Etanol 80\%

Formalina 1\%

Gel de separação contendo acrilamida a $10 \%$ ou $13 \%$.

Glicerol 37\%

Glicina 3,5\%

$\mathrm{H}_{2} \mathrm{SO}_{4}, 4 \mathrm{~N}$.

Hidróxido de alumínio

Leite desnatado a 2,5\% e 5\%

Mercaptoetanol 7,4\%

$\mathrm{NaCl} 0,25 \mathrm{M}$

Nitrato de prata a $20 \%$

Padrões de proteínas com peso molecular conhecido 
PBS

PBS/ Tween a 0,05\%

Ponceau-S a 0,5\%

SDS à $2 \%, \mathrm{pH} 6,8$.

Solução de acetato de sódio, pH 5,0

Solução de cloreto de lítio estéril a 0,1M

Solução cromógena TMB

Solução fixadora de gel (metanol a 50\% e ácido acético a 10\%)

Solução fixadora de gel (etanol à 40\%, ácido acético a 5\% e ácido periódico a 0,031M).

Solução redutora (ácido nítrico a 0,065mM e 0,25mL de formaldeído a 37\%).

Solução saturada de azul de bromofenol 0,9\%.

Substrato AEC (Pierce) a 4\% em solução de acetato de sódio, pH 5,0)

Tampão de acoplamento $\left(\mathrm{NaHCO}_{3} 1,0 \mathrm{M}\right.$ e $\left.\mathrm{NaCl} 0,5 \mathrm{M}, \mathrm{pH} 8,3\right)$

Tampão de amostra [62,5 mM de Tris-hydrochloride, $\mathrm{pH}$ 6,8, 1\% (v/v) glicerol, 2\% de água destilada e $0,5 \%$ de SDS a $10 \%(v / v)]$

Tampão Carbonato-Bicarbonato

Tampão de corrida - Tris-hidroximetilaminometano 0,075 M, glicina 0,576 M e SDS $0,15, \mathrm{pH} 8,3)$

Tampão Fosfato PBS/ azida 0,02\%

Tampão glicina/ $\mathrm{HCl}$ 0,2M, pH 2,8.

Tampão de transferência (Tris-hidroximetilaminometano 25mM, glicina 192mM e metanol 20\%, pH 8,3)

Tampão Tris 1,0M

Tiocionato de Potássio a 1,5M (KSCN) 